\title{
Phytotoxic Secondary Metabolites from Fungi
}

\author{
Dan Xu, Mengyao Xue, Zhen Shen, Xiaowei Jia, Xuwen Hou, Daowan Lai $\mathbb{1}$ and Ligang Zhou *(D) \\ Department of Plant Pathology, College of Plant Protection, China Agricultural University, Beijing 100193, China; \\ cauxudan@cau.edu.cn (D.X.); mengyaoxue@cau.edu.cn (M.X.); zhenshen@cau.edu.cn (Z.S.); \\ xiaoweijia@cau.edu.cn (X.J.); xwhou@cau.edu.cn (X.H.); dwlai@cau.edu.cn (D.L.) \\ * Correspondence: lgzhou@cau.edu.cn; Tel.: +86-10-6273-1199
}

check for updates

Citation: Xu, D.; Xue, M.; Shen, Z.; Jia, X.; Hou, X.; Lai, D.; Zhou, L.

Phytotoxic Secondary Metabolites

from Fungi. Toxins 2021, 13, 261.

https://doi.org/10.3390/

toxins13040261

Received: 24 February 2021

Accepted: 3 April 2021

Published: 6 April 2021

Publisher's Note: MDPI stays neutral with regard to jurisdictional claims in published maps and institutional affiliations.

\begin{abstract}
Fungal phytotoxic secondary metabolites are poisonous substances to plants produced by fungi through naturally occurring biochemical reactions. These metabolites exhibit a high level of diversity in their properties, such as structures, phytotoxic activities, and modes of toxicity. They are mainly isolated from phytopathogenic fungal species in the genera of Alternaria, Botrytis, Colletotrichum, Fusarium, Helminthosporium, and Phoma. Phytotoxins are either host specific or non-host specific phytotoxins. Up to now, at least 545 fungal phytotoxic secondary metabolites, including 207 polyketides, 46 phenols and phenolic acids, 135 terpenoids, 146 nitrogen-containing metabolites, and 11 others, have been reported. Among them, aromatic polyketides and sesquiterpenoids are the main phytotoxic compounds. This review summarizes their chemical structures, sources, and phytotoxic activities. We also discuss their phytotoxic mechanisms and structure-activity relationships to lay the foundation for the future development and application of these promising metabolites as herbicides.
\end{abstract}

Keywords: fungi; plant pathogenic fungi; phytotoxic; herbicidal; phytotoxins; mycotoxins; mycoherbicides; secondary metabolites

Key Contribution: This review describes phytotoxic secondary metabolites from fungi that should be beneficial to the elucidation of fungal phytotoxin diversity and their phytotoxic mechanisms, as well as the development of novel herbicides

\section{Introduction}

Phytotoxic secondary metabolites from fungi (or called fungal phytotoxins) are toxic compounds to plants produced by fungi, especially by plant fungal pathogens responsible for serious diseases of agrarian and forest plants causing significant economical losses [1]. Fungal phytotoxins play an important role in the development of plant disease symptoms, inclduing leaf spots, wilting, chlorosis, necrosis, and growth inhibition and promotion $[2,3]$. Their chemical and biological characterizations as well as the structure-activity relations and modes of action can help us to deeply investigate plant-pathogen interactions.

Fungal phytotoxins are either host specific (HST) or non-host specific (NHST) toxins. Hosts specific phytotoxins (or called host-selective toxins) are active only towards plants that are hosts of the toxin-producing fungi, and are essential for pathogenicity [4]. Host specific toxins are mainly produced by plant pathogenic fungi of Alternaria, Colletotrichum, and Helminthosporium [5,6]. In some cases, host sensitivity is mediated by gene-for-gene interactions, and phytotoxin sensitivity is mandatory for disease development [7]. Contrarily, non-host specific phytotoxins (or called non-host-selective toxins) are primary determinants of host range and not essential for pathogenicity, although they may contribute to virulence. These phytotoxins have a broader range of activity, causing symptoms not only on hosts of the pathogenic fungi, but also on other plant species [8].

Many reviews related to the phytotoxins produced by fungi have been previously published. However, some reviews have been published for a few years [1,8-11]. Some 
discussed only the biochemical and physiological aspects of phytotoxins [12], and some others only proposed fungal phytotoxins as potential herbicides [11,13]. Additionally, other reviews only reported on the phytotoxins produced by one fungal genus $[4,14-16]$, or one fungal species [17]. Some others were reported on the phytotoxins produced by fungi during interactions with one plant species or only one plant group [18]. Furthermore, with the expansion of research scope, more and more fungal phytotoxins with herbicidal potential have been recently revealed from non-phytopathogenic fungi such as plant endophytic fungi [19-21], animal endophytic fungi [22-24], soil-derived fungi [25,26], and marine-derived fungi $[27,28]$.

Fungal phytotoxins belong to different classes such as polyketides, phenols and phenolic acids, terpenoids, nitrogen-containing metabolites based on their biosynthetic pathways and structural characters. To our knowledge, there are no detailed reviews about the phytotoxic secondary metabolites from all fungal species to be published. This review describes fungal phytotoxic metabolites, their structures, isolated fungi and phytotoxic activities. Furthermore, the probable roles played by fungal phytotoxins in the induction of plant disease symptoms, structure-activity relationships, phytotoxic mechanisms, as well as the potential applications in agriculture are also discussed.

\section{Polyketides}

Polyketides are an extremely important class of bioactive secondary metabolites. They are produced by repetitive Claisen condensations of an acyl-coenzyme A (CoA) starter with malonyl-CoA elongation units in a fashion reminiscent of fatty acid biosynthesis. The biosynthesis of polyketides from acyl-CoA thioesters is catalyzed by polyketide synthase (PKS), a multi-enzyme complex that is highly homologous to fatty acid synthase (FAS). The diverse structures of polyketides can be explained as being derived from poly- $\beta$-keto chains, formed by the coupling of acetic acid units via condensation reactions. Although sharing a similar synthetic process, PKSs can be classified into three types, namely type I PKS, type II PKS, and type III PKS. Type I PKSs are multifunctional peptides containing linearly arranged and covalently fused domains. The type I PKSs can be further classified into iterative type I PKSs (iPKSs) and modular type I PKSs (mPKSs). Type II PKSs are multi-enzyme complexes composed of monofunctionall proteins. Type III PKSs are simple homodimers that use CoA rather than acyl carrier protein (ACP) as an anchor for chain extension. In addition, both type II and type III PKSs are iterative [29]. Most fungal phytotoxic metabolites belong to polyketides. They are mainly divided into aromatic and aliphatic polyketides.

\subsection{Aromatic Polyketides}

Aromatic polyketides are characterized by their polycyclic aromatic structures. The biosynthesis of aromatic polyketides is usually accomplished by the type II polyketide synthases (PKSs), which produce highly diverse polyketide chains by sequential condensation of the starter units with extender units, followed by reduction, cyclization, aromatization and tailoring reactions [29]. Many fungal phytotoxic polyketides belong to aromatic polyketides that mainly include benzopyrones, dibenzopyrones, benzophenones, naphthopyrones, azaphilones, naphthalenes, anthraquinones, perylenequinonoids, and aromatic macrolides.

\subsubsection{Benzopyrones}

Phytotoxic benzopyrones from fungi mainly include benzo- $\alpha$-pyrones and benzo- $\gamma$ pyrones. Benzo- $\alpha$-pyrones are also called isocoumarin derivatives. The structures of fungal phytotoxic benzo- $\alpha$-pyrones are shown in Figure 1. 
<smiles>CO[C@@]1(C)Cc2cccc(O)c2C(=O)O1</smiles><smiles>Cc1ccc(O)c2c1C[C@H](C)OC2=O</smiles>

2. 3,4-Dihydro-8-hydroxy-3,5- 3. 3-Methoxy-6,8-dihydroxy-3-

1. Botryoisocoumarin $A$ dimethylisocoumarin<smiles>CO[C@]1(C)Cc2cc(O)cc(O)c2C(=O)O1</smiles>
methyl-3,4-dihydroisocoumarin<smiles>C[C@@H]1OC(=O)c2c(O)ccc(O)c2[C@H]1O</smiles>

4. Neoisocoumarin<smiles>CC(C)Cc1cc2cc(O)cc(O)c2c(=O)o1</smiles>

5. De-O-methyldiaporthin<smiles>CCCC1CC2OC(=O)c3c(cc(OC)c(OC)c3O)C2O1</smiles>

6. Monocerin<smiles>C[C@H]1Cc2cccc(O)c2C(=O)O1</smiles>

7. (-)-R-Mellein<smiles>C[C@]1(O)Cc2cccc(O)c2C(=O)O1</smiles>

8. (-)-R-3-Hydroxymellein<smiles>[R2]C1c2cccc(O)c2C(=O)O[C@@H]1C</smiles>

9. 3R,4R-4-Hydroxymellein, $\mathrm{R}_{1}=\mathrm{OH}, \mathrm{R}_{2}=\mathrm{H}$

10. $3 R, 4 S-4$-Hydroxymellein, $\mathrm{R}_{1}=\mathrm{H}, \mathrm{R}_{2}=\mathrm{OH}$<smiles>[R]c1cc(O)c2c(=O)oc(CC(=O)c3c(C)cc(O)cc3O)cc2c1</smiles>

12. O-Methylated $\mathrm{SMA93}, \mathrm{R}=\mathrm{OCH}_{3}$

Figure 1. Structures of the phytotoxic benzo- $\alpha$-pyrones isolated from fungi.

Botryoisocoumarinn A (1) and neoisocoumarin (4) were isolated from Neufusicoccum batangarum, the causal agent of the scabby canker of cactus pear (Opuntia ficus-indica). Both metabolites induced a necrotic lesions around the inoculation points in both host (cactus pear) and non-host (tomato) plants [30].

Then, 3,4-dihydro-8-hydroxy-3,5-dimethyl isocoumarin (also called 5-methylmellein, 2) was isolated from the culture broth of Diaporthe eres, the leaf pathogen of Hedera helix. This compound caused necrotic lesions on the leaves of $H$. helix. It inhibited seed germination and seedling growth of lettuce (Lactuca sativa) and bentgrass (Agrostis stolonifera). It was much more phytotoxic to bentgrass than to lettuce [31].

In addition, 3-methoxy-6,8-dihydroxy-3-methyl-3,4-dihydroisocoumarin (3) was isolated from Pyricularia grisea, the pathogen of buffelgrass (Cenchrus ciliaris). This metabolite showed a significant stimulating effect on the radical elongation of buffelgrass by seedling growth assay [32].

De-O-methyldiaporthin (5) was isolated from the liquid culture of Drechslera siccans which was the pathogen of oat (Aoena sativa), perennial ryegrass (Lolium perenne), and Italian ryegrass (Lolium multiflorum). Leaf necrosis were observed on corn (Zea mays), crabgrass (Digitaria ischaemum), and soybean (Glycine max) [33].

Monocerin (6) was isolated from Eserohilum turcicum (syn. Drechslera turcica), the leaf pathogen of the noxious weed Johnson grass (Sorghum halepense). This metabolite possessed non-specific phytotoxic activity to inhibit root and shoot growth of Johnson grass and cucumber seedlings [34].

(-)-R-Mellein (7) was isolated from the culture broth of Phoma tracheiphila, the pathogen causing the citrus disease known as mal secco. (-)-R-Mellein (7) induced symptoms of phytotoxicity in tomato cuttings at $100 \mu \mathrm{g} / \mathrm{mL}$ [35]. (-)-R-Mellein (7) was also isolated from Sardiniella urbana, the emerging pathogen on European hackberry [36], and from Neufusicoccum batangarum, the causal agent of the scabby canker of cactus pear [37]. It was toxic to tomato cuttings and young cork oak and holm oak leaves [36], and cactus pear cladode and tomato leaves by puncture assay [37]. 
Four benzopyrones namely (-)-R-mellein (7), (-)-R-3-hydroxymellein (8), 3R,4R-4hydroxymellein (9), and 3R,4S-4-hydroxymellein (10) were isolated from the cultures of Neofusicoccum parvum, the pathogen of Botryosphaeria dieback of grapevine (Vitis vinifera). These four metabolites were phytotoxic to the leaves of grapevine by causing leaf necrosis. Among them, (-)-R-3-hydroxymellein (8) was the most phytotoxic [38]. Both 3R,4R-4hydroxymellein (9) and 3R,4S-4-hydroxymellein (10) were also isolated from Neufusicoccum batangarum, the causal agent of the scabby canker of cactus pear. They induced necrotic lesions around the inoculation points of the cladodes of cactus pear and the leaves of tomato [39].

SMA93 (11) and O-methylated SMA93 (12) were isolated from Fusarium proliferatum ZS07, the endophytic fungus residing in the gut of long-hrned grasshopper (Tettigonia chinensis). They showed inhibitory activity on the radicle growth of Amaranthus retrofleus seedlings [22].

The structures of the fungal phytotoxic benzo- $\gamma$-pyrones (chromenones) are shown in Figure 2. Chloromonilinic acids B (13), C (14), and D (15) were isolated from the liquid cultures of Cochliobolus australiensis, the leaf pathogen of the weed buffelgrass (Pennisetum ciliare). These three chloromonilinic acids were toxic to buffelgrass in a seedling elongation assay, with significantly delayed germination and dramatically reduced radicle growth [40].<smiles>[R]C(C(=O)OC)c1c(/C(Cl)=C\C(=O)O)oc2cc(C)cc(O)c2c1=O</smiles>

13. Chloromonlinic acid $\mathrm{B}, \mathrm{R}=\mathrm{H}$ 14. Chloromonilinc acid $\mathrm{C}, \mathrm{R}=\mathrm{OH}$<smiles>COC(=O)Cc1c(/C(Cl)=C/C(=O)O)oc2cc(C)cc(O)c2c1=O</smiles>

15. Chloromonlinic acid D<smiles>Cc1cc(O)c2c(=O)c3c(oc2c1)CCC3=O</smiles><smiles>COC(=O)[C@]1(O)C=C(Cl)c2oc3cc(C)cc(O)c3c(=O)c21</smiles>

16. Coniochaetone $A$ 17. Rabenchromenone

Figure 2. Structures of the phytotoxic benzo- $\gamma$-pyrones isolated from fungi.

Coniochaetone A (16) and rabenchromenone (17) were isolated from the culture filtrates of Fimetariella rabenhorstii, an oak-decline-associated fungus in Iran. They were toxic by causing a necrosis diameter in the range of $0.2-0.7 \mathrm{~cm}$ with a leaf puncture assay on tomato and oak leaves [41].

\subsubsection{Dibenzopyrones}

Phytotoxic dibenzopyrones from fungi mainly include dibenzo- $\alpha$-pyrones and dibenzo$\gamma$-pyrones. Dibenzo- $\alpha$-pyrones are a group of heptaketide coumarin derivatives that have a fused tricyclic nucleus.

Many fungal dibenzo- $\alpha$-pyrones possess a wide spectrum of biological activities such as cytotoxic, phytotoxic, and antimicrobial activities [42]. The structures of phytotoxic dibenzo$\alpha$-pyrones produced by the fungi from the genera Alternaria are shown in Figure 3.<smiles>[R]Oc1cc(O)c2c(=O)oc3cc(O)cc(C)c3c2c1</smiles>

18. Alternariol, $\mathrm{R}=\mathrm{H}$

19. Alternariol 9-methyl ether, $\mathrm{R}=\mathrm{CH}_{3}$<smiles>COc1cc(O)c2c(c1)C1=C[C@H](O)[C@@H](O)CC1(C)OC(=O)O2</smiles>

20. Altenuene<smiles>COc1cc(O)c2c(c1)C1=C[C@H](O)[C@@H](O)C[C@H]1OC(=O)O2</smiles>

21. Isoaltenuene<smiles>COc1cc2oc(=O)c3c(O)cc(O)cc3c2cc1O</smiles>

22. Altenuisol

Figure 3. Structures of the phytotoxic dibenzo- $\alpha$-pyrones isolated from fungi.

Both alternariol (18) and alternuisol (22) were isolated from the cultures of Alternaria sp., the pathogen of the invasive weed Xanthium italicum. They inhibited shoot and root growth of Pennisetum alopecuroides and Medicago sativa by seedling growth assay [43]. Further stud- 
ies on the mode of action showed that alternariol (18) and alternariol-9-methyl ether (also called AME, 19) from Alternaria alternata inhibited the photosynthetic electron transport chain in isolated spinach chloroplasts [44].

Altenuene (20) and isoaltenuene (21), which were isolated from the marine-derived fungus Alternaria sp. P8, had inhibition on root and hypocotyl elongation of amaranth and lettuce at $200 \mu \mathrm{g} / \mathrm{mL}$ [27].

Dibenzo- $\gamma$-pyrones (also called xanthones) are $9 H$-xanthen-9-one derivatives comprising a family of $O$-heterocycle symmetrical compounds with a dibenzo- $\gamma$-pyrone scaffold. Fungal dibenzo- $\gamma$-pyrones typically occur as completely aromatized dihydro-, tetrahydro-, or hexahydroderivatives. Two dibenzo- $\gamma$-pyrones (Figure 4) namely sterigmatocystin (23) and dihydrosterigmatocystin (24) exhibited potent herbicidal activity resulting in leaf necrosis and wilting. Dihydrosterigmatocystin (24) was more phytotoxic toward Amaranthus retroflexus than sterigmatocystin (23). Additionally, dihydrosterigmatocystin (24) also displayed remarkably herbicidal activity against other amaranthaceous plants including Alternanthera philoxeroides, Amranthus spinosus, and Celosia argentea. Analysis of the structure-herbicidal activity relationship indicated that the bifuranic ring played an important role in dibenzo- $\gamma$-pyrone (xanthone) phytotoxicity and the presence of a double bond in the furan ring could decrease phytotoxicity [45].<smiles>COc1cc2c(c3oc4cccc(O)c4c(=O)c13)[C@H]1C=CO[C@@H]1O2</smiles>

\section{Sterigmatocystin}<smiles></smiles>

24. Dihydrosterigmatocystin

Figure 4. Structures of the phytotoxic dibenzo- $\gamma$-pyrones isolated from fungi.

\subsubsection{Benzophenones}

Benzophenones share a common phenol-carbonyl-phenol skeleton. They are considered as the derivatives of xanthones [45]. The A-ring is derived from the shikimic acid pathway, and the B-ring is derived from the acetate-malonate pathway [46]. The structures of phytotoxic benzophenones from fungi are shown in Figure 5.<smiles>[R]Oc1c(OC)cc(C)cc1C(=O)c1cc(O)cc(OC)c1C=O</smiles>

25. Daldinal $A, R=H$

26. Daldinal $\mathrm{B}, \mathrm{R}=\mathrm{CH}_{3}$<smiles>[R]C1C=CC(C(=O)OC)=C(C(=O)c2c(O)cc(C)cc2O)C1O</smiles>

27. Moniliphenone, $\mathrm{R}=\mathrm{H}$

28. Rabenzophenone, $\mathrm{R}=\mathrm{Cl}$

Figure 5. Structures of the phytotoxic benzophenones isolated from fungi.

Two benzophenones named daldinalds A (25) and B (26) were isolated from Daldinia concentrica. Both metabolites showed inhibition on the root growth with a rice seedling assay [47].

Moniliphenone (27) and rabenzophenone (also called chloromoniliphenone, 28) were isolated from the culture filtrates of Fimetariella rabenhorstii, an oak-decline-associated 
fungus in Iran. They were active by causing a necrosis diameter in the range of $0.2-0.7 \mathrm{~cm}$ with leaf puncture assay on tomato and oak leaves [41]. These two benzophenones were also isolated from the solid culture of Alternaria sonchi, the leaf pathogen of sowthistles (Sonchus spp.). Both metabolites were toxic to the leaves of couch-grass (Elytrigia repens) and sowthistle (Sonchus arvensis) by a punctured leaf disc assay [48].

\subsubsection{Naphthopyrones}

Phytotoxic naphthopyrones from fungi belong to bis-naphthopyrones. Their structures are shown in Figure 6. Bis-naphtho- $\gamma$-pyrones were dimeric naphtha- $\gamma$-pyrones which are an important group of fungal polyketides with a variety of biological activities such as cytotoxic, antitumor, antimicrobial and phytotoxic activities [49]. Four bis-naphtho- $\gamma-$ pyrones, namely isochaetochromin $B_{2}$ (29), and ustilaginoidins $E(30), F(31)$, and $O$ (32), were isolated from rice solid cultures of Ustilaginoidea virens (teleomorph: Villosiclava virens), the pathogen of rice false smut disease. They displayed moderate inhibitory activity on the radicle elongation of rice seedlings. Among them, ustilaginoidin F (31) showed the strongest activity against the rice seeds [50]. Four other bis-naphtho- $\gamma$-pyrones with more polarity, namely ustilaginoidins B (33), I (34), R (35), and U (36), were later isolated from rice false smut balls. They exhibited inhibition on the radicle and germ growth of rice seedlings [51].<smiles>CC1Oc2cc3c(-c4c(O)cc(O)c5c4C=C4OC(C)[C@@H](C)C(=O)C4C5O)c(O)cc(O)c3c(O)c2C(=O)C1C</smiles>

29. Isochaetochromin $B_{2}$<smiles></smiles>

30. Ustilaginoidin $\mathrm{E}$<smiles></smiles>

31. Ustilaginoidin F<smiles>Cc1oc2cc3c(-c4c(O)cc(O)c5c4C=C4OC(C)CC(=O)C4C5O)c(O)cc(O)c3c(O)c2c(=O)c1C</smiles>

32. Ustilaginoidin $\mathrm{O}$<smiles></smiles>

33. Ustilaginoidin $\mathrm{B}$<smiles>COc1cc(O)c2c(O)c3c(=O)cc(C)oc3cc2c1-c1c(O)cc(O)c2c1C=C1O[C@H](C)CC(=O)C1C2O</smiles>

34. Ustilaginoidin I<smiles>C[C@H](O)Cc1cc(=O)c2c(O)c3c(O)cc(O)c(-c4c(O)cc(O)c5c4C=C4OC(CO)=CC(=O)C4C5O)c3cc2o1</smiles>

35. Ustilaginoidin $\mathrm{R}$<smiles>O=C1CC(CO)Oc2cc3c(-c4c(O)cc(O)c5c4C=C4OC(CO)CC(=O)C4C5O)c(O)cc(O)c3c(O)c21</smiles>

36. Ustilaginoidin U

Figure 6. Structures of the phytotoxic bis-naphtho- $\gamma$-pyrones isolated from fungi.

\subsubsection{Azaphilones}

Azaphilones (or called azaphilonoids) are a structurally variable family of fungal polyketide metabolites possessing a highly oxygenated pyranoquinone bicyclic core, usually known as isochromene, and a quaternary carbon center. They belong to a large group of fungal pigments, which turn red in the presence of primary amines due to an exchange of the pyran oxygen for nitrogen, arising from their affinity of the $4 H$-pyran nucleus to undergo substitution with primary amines to form the corresponding vinylogous $\gamma$-pyridones. Some fungal azaphilones showed phytotoxic activities. However, most of azaphilones have not been screened for their phytotoxic activities [52]. The structures of phytotoxic azaphilones from fungi are shown in Figure 7. 
<smiles>C/C=C/C=C/C=C/c1cc(O)c2c3c1C1=C(COC(CO)(CO1)C3=O)C2=O</smiles>

37. Acetosellin<smiles>CC[C@H](C)c1occ2c(=O)c(C(=O)O)c(O)cc-2c1C</smiles>

38. Ascochitine<smiles>CC[C@H](C)/C=C/C1=CC2=C(Cl)C(=O)[C@]3(C)O[C@]4(O)[C@@H](C)[C@@H](C)OC(=O)[C@H]4[C@H]3[C@H]2CO1</smiles>

39. Chaetomugilin $D$<smiles>C/C=C(\C)C(=O)C[C@H]1C2=COC(/C=C/[C@H](C)CC)=CC2=C(Cl)C(=O)[C@H]1O</smiles>

40. Chaetomugilin $\mathrm{J}$<smiles>CC[C@H](C)C[C@H](C)C(=O)O[C@@]1(C)C(=O)C=C2C=C(/C=C/C(=O)O)OC=C2C1=O</smiles>

41. Lunatoic acid $A$<smiles>CC[C@]1(C)C(=O)CC2C(=COC(C)=C2C)C1=O</smiles>

42. Spiciferinone

Figure 7. Structures of the phytotoxic azaphilones isolated from fungi.

Acetosellin (37) was isolated from the mycelia of Cercosporella acetosella, the pathogen of leaf spots of the cosmopolitan weed (Rumex acetosella). It inhibited root elongation of Lepidium sativum and Zea mais at $6.4 \times 10^{-4} \mathrm{M}$ [53].

Ascochitine (38) was produced as a main phytotoxin from Ascochyta fabae and A. pisi, two pathogens that caused the so called 'brown spots' disease in broad bean and necrotic lesions on pea leaflets [54]. This compound was later isolated from the cultures of Phoma clematidina, the pathogen of leaf spot-wilt disease of Clematis sp. This metabolite was toxic to the leaves of Clematis sp. by leaf disc assay [55].

Chaetomugilins D (39) and J (40) were isolated from Chaetomium globosum, the endophytic fungus from the leaves of Amaranthus viridis. Both compounds showed phytotoxic activity in the lettuce (Lactuca sativa) seed germination assay [20].

Lunatoic acid A (41) was isolated from Cladosporium oxysporum DH14, the fungus residing in the gut of locust (Oxya chinensis). This metabolite exhibited significant inhibition against radicle growth of Amaranthus retroflexus seedlings [24].

Spiciferinone (42) was isolated from the culture filtrates of Cochliobolus spicifer, the pathogen of leaf spot disease in Gramineae. This metabolite was phytotoxic to wheat cotyledons by using protoplast viability assay [56].

\subsubsection{Naphthalene Derivatives}

Phytotoxic fungal naphthalene derivatives include naphthols, naphthoquinones, and naphthalenones. One naphthol and seven naphthoquinones with phytotoxicity were found in fungi. Their structures are shown in Figure 8.

Agropyrenal (43), a naphthol, was isolated from the liquid cultures of Ascochyta agropyrina var. nana. When the leaves of several weed plants (i.e., Mercurialis annua, Chenopodium album and Setaria viridis) were assayed, agropyrenal (43) was proved to be phytotoxic by causing the appearance of necrotic lesions [57].

Three naphthoquinone derivatives, 6-hydroxy-astropaquinone B (44), astropaquinone $\mathrm{D}$ (45) and 3-O-methyl-9-O-methylfusarubin (46) were isolated from Fusarium napiforme, an endophytic fungus isolated from the mangrove plant, Rhizophora mucronata. They inhibited growth of lettuce seedlings at concentration of $30 \mu \mathrm{g} / \mathrm{mL}$ [58]. 
<smiles>COc1c(O)ccc2c(C)ccc(C=O)c12</smiles>

43. Agropyrenal<smiles>[R]C1O[C@H](C)CC2=C1C(=O)c1c(OC)cc(OC)c(O)c1C2=O</smiles>

44. 6-Hydroxy-astropaquinone $\mathrm{B}, \mathrm{R}=\mathrm{OCH}_{3}$ 45. Astropaquinone $D, R=H$<smiles>COc1cc(OC)c2c(c1O)C(=O)C1=C(C[C@](C)(OC)OC1)C2=O</smiles>

46. 3-O-Methyl-9-O-methylfusarubin<smiles>COc1cc(OC)c2c(c1)C(=O)C1=C(CO[C@](C)(O)C1)C2=O</smiles>

47. Herbarin<smiles>O=C1C=C(O)C(=O)c2c(O)cccc21</smiles>

48. 2-Hydroxyjuglone<smiles>Cc1cc(O)c2c(c1)C(=O)C1=C(OCC(O)=C1O)C2=O</smiles>

49. Lentiquinone $A$<smiles>COc1cc(OC)c2c(c1)C(=O)C(CC(C)=O)=C(C)C2=O</smiles>

50. Nectriaquinone $A$

Figure 8. Structures of the phytotoxic naphthol and naphthoquinone congeners isolated from fungi.

Herbarin (47) and nectriaquinone A (50) isolated from Nectria pseudothichia 120-1 NP inhibited the growth of lettuce (Lactuca sativa L.) seedlings. Herbarin (47) showed stronger phytotoxicity than nectriaquinone A (50) [59].

Further, 2-hydroxyjuglone (48) was isolated from the culture broth of Ceratocystis fimbriata f.sp. platani, the canker pathogen of plane tree (Platanus orientalis). This compound induced large necrotic lesions in stem explants of plane tree as was observed in vivo [60].

Lentiquinone A (49) was isolated from Ascochyta lentis, the pathogen of lentil (Lens culinaris). It exhibited a strong phytotoxicity to the punctured leaves and seed germination of host and non-host plants [61].

The structures of phytotoxic naphthalenone derivatives from fungi are shown in Figure 9. Six polysubstituted octahydro-naphthalen-1-ones, named betaenones A-F (51-56) were isolated from Phoma betae, the causal agent of leaf spot disease of sugar beet. Among these metabolites, betaenone $C$ (53) exhibited the highest phytotoxic activity to cause wilting of sugar beet at $50 \mu \mathrm{g} / \mathrm{mL}$, and highest root growth inhibitory effect $(89 \%)$ against rice seedlings at $37 \mu \mathrm{g} / \mathrm{mL}[62,63]$.

Four naphthalenones were isolated from Botrytis fabae, the pathogen of faba bean (Vicia faba) by displaying clear chocolate spot symptom. They were named as botrytone (57), cis- and trans-3,4-dihydro-2,4,8-trihydroxynaphthalene-1(2H)-ones (58 and 59), and regiolone (60) [64].

Scytalone (61) and isosclerone (62) were two phytotoxic metabolites produced by both Phaeoacremonium aleophilum (syn. P. miimum) and P. chlamydospora, the causal agent of esca disease [65]. Scytalone (61) was also isolated from Raffaelea quercivora which was the pathogen of Japanese oak wilt disease [66], and from Ceratocystis imbriata f.sp. platani which was the canker pathogen of plane tree (Platanus occidentalis) [60]. This compound exhibited weak phytotoxic activity by inhibiting root growth of lettuce seedlings [66], and caused significant leaf necrosis on the cutting seedlings of plane tree [60]. Phytotoxic scytalone (61), isolerone (62), and cis-4-hydroxyscytalone (63) were also isolated from P. aleophilum by another research group [67].

Both 2,4,8-trihydroxytetralone (64) and 3,4,8-trihydroxytetralone (66) from Phaeoacremonium aleophilum inhibited callus growth of grapevine [68]. 3,4,5-Trihydroxytetralone (65) and 3,4,8-trihydroxytetralone (66), which were isolated from the fungus Hypoxylon mammatum, the stem canker pathogen of aspen (Populus sp.), were toxic to the aspen leaves by leaf assay [69]. 


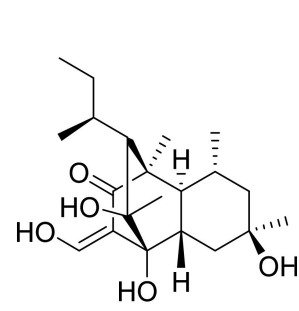

51. Betaenone A

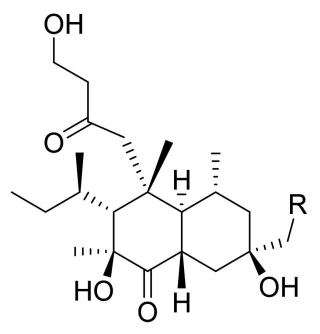

52. Betaenone $\mathrm{B}, \mathrm{R}=\mathrm{H}$ 54. Betaenone $D, R=O H$<smiles>CCC(C)[C@@H]1[C@H]2CC[C@@H](O)C[C@@]2(O)C(=O)[C@]1(C)O</smiles>

53. Betaenone C

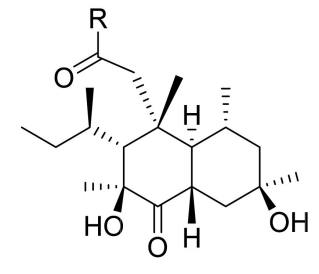

55. Betaenone $\mathrm{E}, \mathrm{R}=\mathrm{CH}_{3}$ 56. Betaenone $\mathrm{F}, \mathrm{R}=\mathrm{CH}_{2} \mathrm{CH}_{2} \mathrm{OAc}$<smiles>[R]c1ccc(O)c2c1C(=O)CC[C@H]2O</smiles>

57. Botrytone, $\mathrm{R}=\mathrm{OH}$ 60. Rgiolone, $\mathrm{R}=\mathrm{H}$<smiles>O=C1c2c(O)ccc(O)c2[C@@H](O)C[C@H]1O</smiles>

58. cis-3,4-Dihydro-2,4,8trihydroxynaphthalenone<smiles>O=C1c2c(O)ccc(O)c2C(O)CC1O</smiles>

59. trans-3,4-Dihydro-2,4,8trihydroxynaphthalenone<smiles>O=C1CC[C@H](O)c2cccc(O)c21</smiles>

62. Isosclerone<smiles>[R]C1c2cc(O)cc(O)c2C(=O)CC1O</smiles>

61. Scytalone, $\mathrm{R}=\mathrm{H}$<smiles>[R]C1C(=O)c2c(O)cccc2C(=O)C1O</smiles>
64. 2,4,8-Trihydroxytetralone, $\mathrm{R}_{1}=\mathrm{OH}, \mathrm{R}_{2}=\mathrm{H}$
66. 3,4,8-Trihydroxytetralone, $\mathrm{R}_{1}=\mathrm{H}, \mathrm{R}_{2}=\mathrm{OH}$<smiles>O=C1CC(O)C(O)c2c(O)cccc21</smiles>

65. 3,4,5-Trihydroxytetralone

Figure 9. Structures of the phytotoxic naphthalenone congeners isolated from fungi.

Spirobisnaphthalenes (also called bisnaphthospiroketals or spirodioxynaphthalenes) have a unique structure in which two napthalenes are connected by spiroketal or binaphalene spiroether. Most of these metabolites isolated from fungi exhibit significant phytotoxic, antimicrobial, and cytotoxic activities to show great potential applications in medicine and agriculture $[70,71]$. The structures of phytotoxic spirobisnaphthalenes from fungi are shown in Figure 10.<smiles></smiles>

67. Palmarumycin C9<smiles>COc1cccc2c1OCCO2</smiles>

68. Palmarumycin CP19 69. Palmarumycin EG1

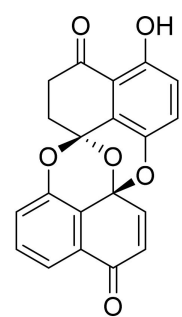

71. Palmarumycin $\mathrm{EG} 3, \mathrm{R}=\mathrm{OCH}_{3}$ 72. Palmarumycin $\mathrm{EG} 4, \mathrm{R}=\mathrm{H}$

Figure 10. Structures of the phytotoxic spirobisnaphthalenes isolated from fungi.

Palmarumycin C9 (67) was isolated from the cultures of Coniothyrium sp. to show herbicidal activity by inhibiting the growth of the cultured cells of algae, lemna, and corn [72].

Palmarumycins CP19 (68), EG1 (69), EG2 (70), EG3 (71) and EG4 (72) were isolated from the mycelial fermentation cultures of the endophytic fungus Edenia gomezpompae from the plant Callicarpa acuminata (Verbenaceae). Among them, palmarumycins EG1-EG4 (69-72) inhibited seed germination of Amaranthus hypochondriacus, Solanum lycopersicum, and Echinochloa crus-galli by more than 50\%. Palmarumycins CP19 (68), EG2 (70), and EG3 (71) inhibited root elongation of $A$. hypochondriacus and E. crus-galli seedlings by more than $50 \%$. These five palmarumycins also inhibited the oxygen consumption of three plant seedlings [73]. 


\subsubsection{Anthraquinones}

Anthraquinones are a group of polyketides containing eight $\mathrm{C} 2$ units, which generates in turn with three aldol type condensations of the carbon skeleton of anthraquinones except for the two carbonyl oxygens of the central ring [74]. The structures of fungal phytotoxic anthraquinones are shown in Figure 11.<smiles>COc1cc(OC)c2c(c1)C(=O)c1cc(OC)c(C)cc1C2=O</smiles>

73. Altersolanol A<smiles>COc1cc(O)c2c(c1)C(=O)C1=C(C2=O)[C@H](O)[C@H](O)[C@](C)(O)[C@H]1O</smiles>

74. Altersolanol J<smiles>Cc1c(O)cc2c(c1C)C(=O)c1cc(O)c(C)c(C)c1C2=O</smiles>

75. Neoanthraquinone<smiles>[R]C1c2c(O)c3c(c(O)c2C[C@@](C)(O)[C@@H]1O)C(=O)C=C(OC)C3=O</smiles>

76. Bostrycin, $\mathrm{R}=\mathrm{OH}$

77. 4-Dexoybostrycin, $\mathrm{R}=\mathrm{H}$<smiles>[R]c1c(C)cc(O)c2c1C(=O)c1cc(O)cc(O)c1C2=O</smiles>

78. Catenarin, $\mathrm{R}=\mathrm{OH}$ 86. Emodin, $\mathrm{R}=\mathrm{H}$<smiles>[R]C1C2=C(C[C@](C)(O)[C@@H]1O)C(=O)c1cc(OC)cc(O)c1C2=O</smiles>

79. Dactylariol, $\mathrm{R}=\mathrm{H}$ 101. Stemphylin $\mathrm{R}=\mathrm{OH}$<smiles>[R]C1C=C2C(=O)c3cc(C)cc(O)c3[C@@H](O)[C@@]2(O)[C@H](O)[C@H]1O</smiles>

80. Dendryol $A, R=H$ 83. Dendryol $D, \mathrm{R}=\mathrm{OH}$<smiles>[R]C1C[C@H]2C(=O)c3cc(C)cc(O)c3[C@@H](O)[C@]2(C)[C@H](O)[C@@H]1O</smiles>

81. Dendryol $B, \mathrm{R}=\mathrm{OH}$ 82. Dendryol $\mathrm{C}, \mathrm{R}=\mathrm{H}$<smiles>[R]c1cc(O)c2c(c1)C(=O)c1cc([R])c([R])cc1C2=O</smiles>

84. 1,7-Dihydroxy-3-methylanthracene-9,10-dione, $\mathrm{R}_{1}=\mathrm{CH}_{2} \mathrm{OH}, \mathrm{R}_{2}=\mathrm{R}_{3}=\mathrm{H}$

87. $\omega$-Hydroxypachydasin, $\mathrm{R}_{1}=\mathrm{CH}_{3}, \mathrm{R}_{2}=\mathrm{H}, \mathrm{R}_{3}=\mathrm{OH}$ 97. Phomarin, $\mathrm{R}_{1}=\mathrm{CH}_{3}, \mathrm{R}_{2}=\mathrm{OH}, \mathrm{R}_{3}=\mathrm{H}$<smiles>O=C1c2c(O)ccc(O)c2C(=O)c2c(O)c3c(c(O)c21)OC1OC(O)CC31O</smiles>

85. Dothistromin<smiles>[R]C1C=C2C(=O)c3cc(C)cc(O)c3[C@@H](O)[C@@H]2[C@H](O)[C@@H]1O</smiles>

88. Lentiquinone $B, R=\alpha-O H$ 89. Lentiquinone $C, R=\beta-O H$<smiles>Cc1cc(O)c2c(c1)C(=O)C1=C(C[C@H](O)[C@H](O)[C@H]1O)C2=O</smiles>

90. Lentisone<smiles>[R]c1cc2c(cc1C)C(=O)c1cc(OC)cc(O)c1C2=O</smiles>

91. Macrosporin, $\mathrm{R}=\mathrm{OH}$ 95. 6-Methylxanthopurpurin 3-methyl ether, $\mathrm{R}=\mathrm{H}$<smiles>COc1cc(OC)c2c(c1)C(=O)c1c(cc3c(c1O)[C@H]1OC(C)(CC[C@H]1O)O3)C2=O</smiles>

92. 6.8-Di-O-methyl nidurufin<smiles>[R]c1c2c(c([R])c3c1C(=O)C=C(OC)C3=O)C[C@H](O)[C@](C)(O)C2</smiles>

93. Nigrosporin $A, R_{1}=O H, R_{2}=H$ 94. Nigrosporin $B, R_{1}=H, R_{2}=O H$<smiles>COc1cccc2c(-c3c(O)cc(O)c4c3C(=O)c3cc(C)cc(O)c3C4=O)c3c(c(O)c12)C(=O)CC(N)=C3</smiles>

96. Anhydropseudophlegmacin-9,10quinone-3'-amino-8'-O-mehyl ether<smiles>COc1cc(O)cc2c1C(=O)c1c(O)cc(C)cc1C2=O</smiles>

98. Questin<smiles>CC(=O)c1c(O)cc(O)c2c1C(=O)c1cc(O)cc(O)c1C2=O</smiles>

99. Rhodolamprometrin<smiles>C[C@@H](O)Cc1cc(O)c2c(c1)C(=O)c1cc(O)cc(O)c1C2=O</smiles>

100. Isorhodoptilometrin<smiles>COc1cc(OC)c2c(c1)C(=O)c1c(cc(O)c(C(CO)CCO)c1O)C2=O</smiles>

102. 6.8-Di-O-methyl versiconol

Figure 11. Structures of the phytotoxic anthraquinones isolated from fungi. 
Two anthraquinones, namely altersolanols A (73) and J (74), were isolated from the pathogen Phomopsis foeniculi (teleomorph: Diaporthe angelicae) of fennel (Foeniculum vulgare). They showed a modulated phytotoxicity on the detached tomato leaves [75]. Altersolanol A (73) was also isolated from Alternaria porri. This compound inhibited growth of lettuce and stone-leek seedlings [76].

Neoanthraquinone (75) was isolated from Neofusicoccum luteum, the causal agent of Botryosphaeria dieback in Australia. Neoanthraquinone (75) showed the obvious toxic effect by causing severe shriveling and withering on grapevine by leaf assay [37].

Both bostrycin (76) and 4-deoxybostrycin (77) were isolated from the culture filtrates of Alternaria eichhorniae, the pathogen of the water hyacinth (Eichhornia crassipes). These two compounds induced leaf necrosis on water hyacinth [77]. Bostrycin (76) was also isolated from Alternaria alternata, another pathogen of water hyacinth [78].

Catenarin (78) was produced by the necrotrophic fungus Pyrenophora tritici-repentis (anamorph: Drechslera tritici-repentis), the causal agent of tan spot foliar pathogen of wheat. Catenarin (78) induced necrosis on the leaves of wheat. It also infected wheat kernels by causing a red discoloration known as red smudge [79].

Dactylariol (79), macrosporin (91), and stemphylin (101) were produced by Stemphylium botryosum, the pathogen inducing a destructive disease of lettuce. They caused sunken necrotic brown lesions of lettuce leaves by leaf puncture assay [80].

Dendryols A-D (80-83) were produced by Dendryphiella sp., the fungus isolated from an infected sample of the paddy weed Eleocharis kuroguwai (Cyperaceae) in Japan. When tested for the phytotoxic activity by a leaf-puncture assay on weeds (kuroguwai, barnyardgrass, and velvetleaf) and cultivated crops (rice, corn, and cowpea), dendryols A-D (80-83) showed toxicity only against barnyardgrass and the nercrotic area appeared to be dose-dependent, and dendryol A (83) caused similar necrosis only on velvetleaf [81].

Moreover, 1,7-dihydroxy-3-methylanthracene-9,10-dione (84), $\omega$-hydroxypachybasin (87), lentisone (90), and phomarin (97) were isolated from the culture filtrates of Ascochyta lentis, the pathogen of lentil (Lens culinaris). These compounds caused severe necrosis to the punctured leaves and inhibited seed germination of lentil [61].

Dothistromin (85) was isolated as the main phytotoxin produced by Dothistroma pini, the pathogen by causing necrotic disease characterized by the formation of red bands on the infected needles of Pinus radiata and other pines [82].

Emodin (86) has been identified in many fungi [83] and plants [84,85]. Emodin (86) isolated from the coprophilous fungus Guanomyces polythrix showed inhibition on seedling radicle growth of weeds Amaranthus hypochondriacus and Echinochloa crusgalli [86].

Lentiquinones B (88) and C (89) were isolated from Ascochyta lentis, the pathogen of lentil (Lens culinaris). Both compounds caused severe leaf necrosis when applied to the punctured leaves of host and non-host plants. [61].

Lentisone (90) was an anthraquinone produced by Ascochyta lentis. This metabolite was phytotoxic to lentil (Lens culinaris), and was light-dependent [87].

Macrosporin (91) and 6-methylxanthopurpurin 3-methyl ether (95) were isolated from Alternaria bataticola which was the causal fungus to black spot of sweet potato [88]. Macrosporin (91) was also isolated from Stemphyfium botryosum. It was toxic to lettuce by leaf punctrue assay [80].

Both 6,8-di-O-methyl nidurufin (92) and 6,8-di-O-methyl versiconol (102) were isolated from the solid cultures of Penicillium purpurogenum derived from soil. These two compounds inhibited root and hypocotyl growth of radish seedlings at $100 \mu \mathrm{M}$ [26].

Both nigrosporins A (93) and B (94) were isolated from the culture filtrates of Nigrospora oryzae. The two compounds showed significant necrotic effects in leaf puncture assay on green foxtail (Setaria viridis), barnyardgrass (Echinochloa crus-galli), velvetleaf (Abutilon theophrasti), corn (Zea mays), and cowpea (Vigna sesquipedalis). They also had an inhibition on root elongation of lettuce seedlings [89].

An anhydropseudophlegmacin-quinone named anhydropseudophlegmacin-9, 10 quinone-3'-amino- $8^{\prime}-O$-methyl ether (96) was isolated from the filtrate of Phoma herbarum 
FGCC\#54. This compound was a dimeric anthraquinone. It was toxic to the weeds Parthenium hysterophorus, Lantana camara and Hyptis suaveolens to show its herbicidal potential against the prominent weeds [90].

Questin (98) and isorhodoptilometrin (100) were isolated from the endophytic fungus Aspergillus sp. YL-6 residing in Pleioblastus amarus. Both anthraquinones inhibited the seed germination and seedling growth of wheat (Triticum aestivum) and radish (Rahanus sativus). Questin (98) obviously inhibited shoot and root elongation of wheat seedlings [91].

Rhodolamprometrin (99) was isolated from Fusarium proliferatum ZS07, the endophytic fungus residing in the gut of long-horned grasshopper (Tettigonia chinensis). This compound exhibited inhibitory activity on the radicle growth of Amaranthus retrofleus seeds to show its potential as a biocontrol agent in agriculture [22].

\subsubsection{Perylenequinonoids}

Perylenequinonoids are a class of aromatic polyketides characterized by a pentacyclic conjugated chromophore. Fungal perylenequinones are the photoactivated phytotoxins which act by absorbing light energy and generating reactive oxygen species that damage host plant cells [92]. The structures of phytotoxic perylenequinonoids from fungi are shown in Figure 12.<smiles>O=C1C=C[C@]2(O)c3c(ccc(O)c31)-c1ccc(O)c3c1[C@@]2(O)[C@H](O)[C@H](O)C3=O</smiles>

103. Alterlosin I

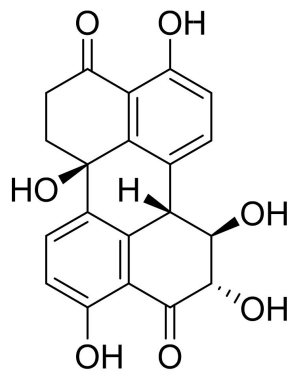

104. Alterloxin II

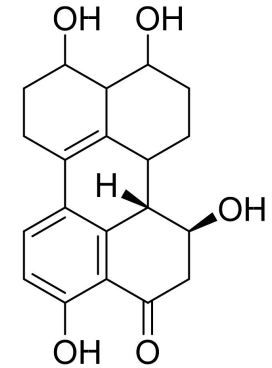

105. Alterperylenol<smiles>O=C1CC[C@]2(O)c3c(ccc(O)c31)-c1ccc(O)c3c1C2C3(O)O</smiles>

106. Altertoxin I<smiles>COc1cc(O)c2c(=O)c(=O)c(OC)c(CC(C)OC(=O)c3ccccc3)c=2c2c(CC[C@H](C)OC(=O)Oc3ccc(O)cc3)c1-c1c(OC)c(O)cc(OC)c1-2</smiles>

107. Calphostin $C$<smiles>COC1=C(C[C@H](C)O)c2c3c(C[C@H](C)O)c(OC)c(=O)c4c(O)cc5c6c(cc(O)c(c2c3c64)C1=O)OCO5</smiles>

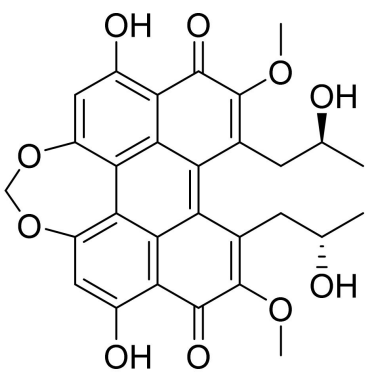

109. Isocercosporin<smiles></smiles>

110. Elsinochroe $A$<smiles>O=C1CC[C@]2(O)c3c1ccc(O)c3-c1ccc(O)c3c1C2C1OC31</smiles>

111. Stemphyltoxin II

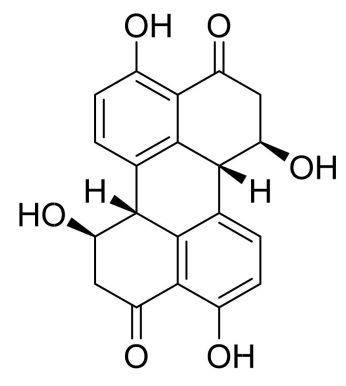

112. Stemphyperylenol

Figure 12. Structures of the phytotoxic perylenequinonoids isolated from fungi.

Alterlosins I (103) and II (104) were isolated from the cultures of Alternaria alternata, the pathogen of spotted knapweed (Centaurea maculosa), a major weed pest in rangelands 
of the northwestern United States and southwestern Canada. Both metabolites induced necrotic lesions on knapweed by a leaf puncture assay. Alterlosin I (103) induced larger necrotic lesions compared to the small flecks induced by alterlosin II (104) [93].

Four perylenequinone congeners alterperylenol (also called alteichin, 105), altertoxin I (106), stemphyltoxin II (111), and stemphyperylenol (112) were isolated from Alternaria cassiae, the pathogen of sicklepod (Cassia obtusifolia). They were toxic to sicklepod, corn, crabgrass, timothy and soybean to cause leaf necrosis by leaf puncture assay. Stemphyperylenol (112) was a selective toxin for crabgrass, while altertoxin I (106) was selective for corn B73 [94].

Three perylenequinonoids named alterperylenol (105), altertoxin I (106) and stemphyperylenol (112) were isolated from the marine-derived fungus Alternaria sp. P8. They showed inhibition on root and hypocotyl elongation of amaranth and lettuce seedlings at $50 \mu \mathrm{g} / \mathrm{mL}$ [27].

Calphostin C (107) was isolated from plant pathogen Cladosporium cladosporioides. This metabolite was a protein kinase C (PKC) inhibitor by competing at the binding site for diacyglycerol and phorbol esters. Specific inhibitor of PKC would be very useful for calphostin C (107) as the pharmacological tool and potential drug [95].

Cercosporin (108) was isolated from cultures of Cercospora nicotianae, and was tested for toxic effects on suspension-cultured cells of tobacco. Cercosporin (108) was toxic to tobacco cells only when it was incubated under the light [96]. It was found that cercosporin (108) can be produced by a few pathogenic fungi in the genus Cercospora. It was toxic to plants by the generation of activated oxygen species, particularly singlet oxygen. Cercospora fungi penetrate host tissues through the stomata and colonize the intercellular spaces. Production of the membrane-damaging cercosporin (108) would allow for cell breakdown and leakage of nutrients required by the fungi for growth and sporulation in the host plant [97]. Isocercosporin (109) was isolated from Scolecotrichum graminis, the causal fungus of a leaf streak disease of orchardgrass. This metabolite was higher toxic than cercosporin (108) by lettuce seedling growth assay [98].

Elsinochrome A (110) was isolated from Stagonospora convolvuli, the biocontrol fungus to bindweed (Convolvulus arvensis). This metabolite showed inhibition on the root elongation of tomato by seedling growth assay, and toxic to bindweed and grapevine leaves by leaf-wounded assay [99].

\subsubsection{Aromatic Macrolides}

Aromatic macrolides are a class of fungal polyketides possessing a macrolide core structures fused into an aromatic ring. The typical metabolites are benzenediol lactones. They have various biological activities such as phytotoxic, cytotoxic, and nematicidal activities. The structures of phytotoxic aromatic macrolides from fungi are shown in Figure 13.<smiles>CO[C@H](C)CCCCCC(=O)c1c(O)cc(O)cc1CC(=O)O</smiles>

113. Curvularin<smiles></smiles>

114. $\alpha, \beta$-Dehydrocurvularin<smiles>COc1cc(O)cc(CCCCCCC[C@@H](C)O)c1C(=O)O</smiles>

115. (3R)-Lasiodiplodin<smiles>[R]C1CCCCCCc2cc(O)cc(O)c2C1=O</smiles>

116. (15S)-de-O-Methyllasiodiplodin, $\mathrm{R}=\mathrm{H}$ 117. (14S,15S)-14-Hydroxy-de-O-methyl lasiodiplodin, $\mathrm{R}=\mathrm{OH}$<smiles>C[C@H]1CCC/C=C\C(=O)Cc2cc(O)cc(O)c2C(=O)O1</smiles>

118. cis-Resorcylide<smiles>CCC/C=C/C(=O)Cc1cc(O)cc(O)c1C(=O)OC(C)C</smiles>

119. trans-Resorcylide

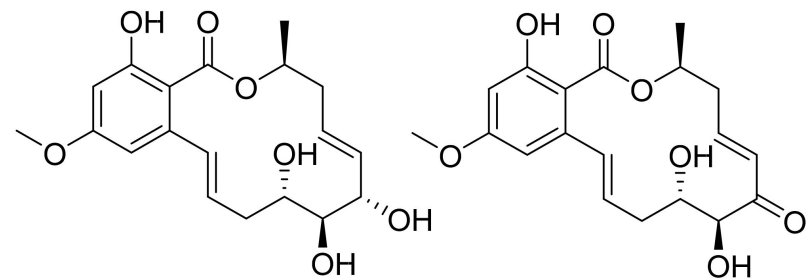

120. Zeaenol
121. 5Z-7-Oxozeaenol

Figure 13. Structures of the phytotoxic aromatic macrolides isolated from fungi. 
Curvularin (113) and $\alpha, \beta$-dehydrocurvularin (114) were isolated from the cultures of Curvularia intermedia, the leaf pathogen of Pandanus amaryllifolius. Both metabolites were toxic to lettuce (Lactuca sativa) and bentgrass (Agrostis stolonifera) with seed germinatin assay [100]. In addition, $\alpha, \beta$-dehydrocurvularin (114) was isolated from the culture filtrates of Alternaria zinnia, the fungus causing leaf necrosis of Xanthium occidentale. It was toxic to the test plants by using leaf puncture assay [101]. $\alpha, \beta$-Dehydrocurvularin (114) was also isolated from Nectria galligena, the apple canker pathogen in Chile. This compound significantly reduced elongation and epicotyl growth of lettuce seedlings [102].

(3R)-Lasiodiplodin (115), which was isolated from Botryosphaeria rhodina, inhibited photophosphorylation and electron transport chain in thylakoids. (3R)-Lasiodiplodin (115) behaved as a Hill reaction inhibitor of the oxygen-evolving complex on chloroplasts. It also interacted at coupling factor $1\left(\mathrm{CF}_{1}\right)$ by inhibiting $\mathrm{CF}_{1} \mathrm{Mg}^{2+}$-ATPase activity [103].

Two $\beta$-resorcylic acid derivatives namely (15S)-de-O-methyllasiodiplodin (116) and $(14 S, 15 S)$-14-hydroxy-de-O-methyllasiodiplodin (117) were isolated from rice fermentation cultures of the endophytic fungus Lasiodiplodia theobromae derived from the mangrove plant Xylocarpus granatum. Both compounds inhibited root elongation of Digitaria ciliaris [104].

Both cis-resorcylide (118) and trans-resorcylide (119) isolated from Penicillium sp. inhibited root elongation of the seedlings of Chinese cabbage, lettuce, and rice, whereas trans-Resorcylide (119) was more phytotoxic than cis-resorcylide (118) [105].

Zeaenol (120) and 5Z-7-oxozeaenol (121) were isolated from the fermentation broth of Cladosporium oxysporum DH14, a locust-associated fungus. Both compounds exhibited significantly phytotoxic activities against the radicle growth of Amaranthus retroflexus seedlings with $\mathrm{IC}_{50}$ values of $8.16 \mu \mathrm{g} / \mathrm{mL}$ and $4.80 \mu \mathrm{g} / \mathrm{mL}$, respectively [24].

\subsection{Aliphatic Polyketides}

Aliphatic polyketides usually have either linear or macrocyclic non-aromatic carbon frameworks, many of which are lactones. Aliphatic polyketides mainly include furan and furanone analogues, aromatic-free pyrones, furopyrans, macrolides, sorbicillinoids, and linear polyketides.

\subsubsection{Simple Furan and Furanone Analogues}

The structures of phytotoxic furan and furanone analogues from fungi are shown in Figure 14. (-)-Botryodiplodin (122) was isolated from the cultures of Botryodiplodia thebromae, the pathogen of soybean charcoal rot disease. (-)-Botryodiplodin (122) was a simple lactol analogue which was toxic to soybean and duckweed (Lemna pausicostata) [106]. This compound has been synthesized by using stereoselective radical cyclizations of acyclic esters and acetals [107].

Two furan derivatives, namely 2,5-dihydroxymethylfuran (123) and 5-hydroxymethy lfuraldehyde (124), were isolated from the cultures of Stilbocrea macrostoma, the fungal pathogen of the tree Quercus brantii, by inducing wood necrosis [108].

(3aS,6aR)-4,5-Dimethyl-3,3a,6,6a-tetrhydro-2H-cyclopenta [b]furan-2-one (125) and myrotheciumone A (126) were isolated from fermentation broth of endophytic fungus Xylaria curta 92092022. Both compounds inhibited hypocotyl and root growth of lettuce seedlings [109].

Nigrosporione (127) was isolated from Neofusicoccum luteum, the causal agent of Botryosphaeria dieback in Australia. It showed the phytotoxic effect by causing severe shriveling and withering on grapevine by leaf assay [37].

Papyracilic acid (128) was a 1,6-dioxaspiro[4,4]nonene isolated from the solid culture of Ascohyta agropyrina var. nana, the leaf pathogen of quack grass (Elytrigia repens). This compound was toxic to host plant and a number of non-host plants of the fungus. It was considered as the potential mycoherbicide for control of E. repens [110]. 

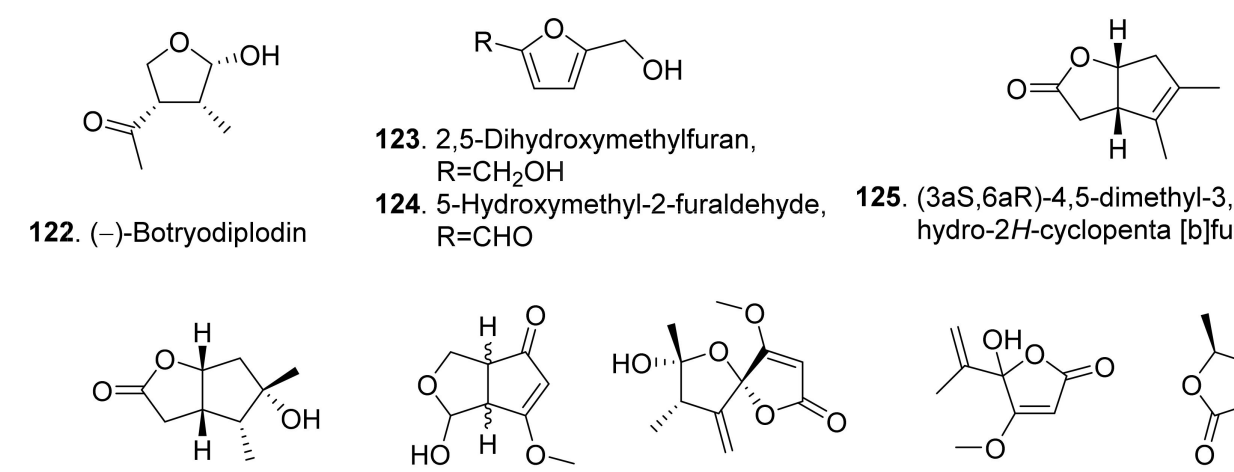

$\mathrm{R}=\mathrm{CH}_{2} \mathrm{OH}$

$\mathrm{R}=\mathrm{CHO}$
-Hydroxymethyl-2-furaldehyde,

125. (3aS,6aR)-4,5-dimethyl-3,3a,6,6a-tetra-
hydro-2H-cyclopenta [b]furan-2-one
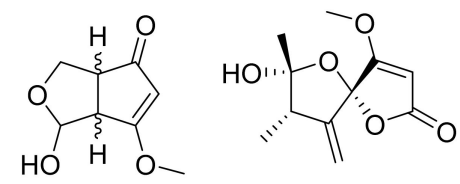<smiles>C=C(C)C1(O)OC(=O)C=C1OC</smiles><smiles>C[C@H]1OC(=O)[C@H]2OC(=O)C[C@@H]21</smiles>

126. Myrotheciummone $A$

127. Nigrosporione 128. Papyracillic acid

129. Penicillic acid 130. Quercilactone A<smiles>[R]C([R])(/C=C\C=C/C)C1CCC(=O)O1</smiles>

131. Sapinofuranone $A, R_{1}=O H, R_{2}=H$ 132. Sapinofuranone $B, R_{1}=H, R_{2}=O H$

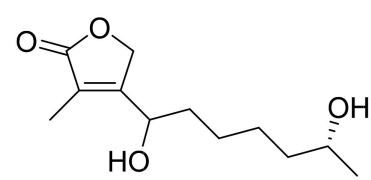

133. Seiridin, $\mathrm{R}=\mathrm{H}$ 134. $7^{\prime}$-Hydroxyseiridin, $\mathrm{R}=\mathrm{OH}$

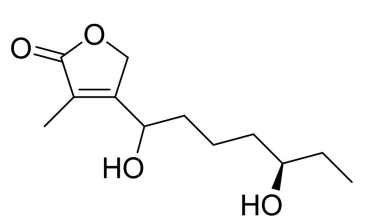

135. Isoseiridin, $\mathrm{R}=\mathrm{H}$

136. 7 '-Hydroxyisoseiridin, $\mathrm{R}=\mathrm{OH}$<smiles>CC[C@@H]1CCC(C2C(=O)O[C@@H](C)C2=O)O1</smiles>

137. Terrestric acid<smiles>C/C=C/CCC(=O)CC[C@]1(C)OC(=O)C(C)=C1O</smiles>

138. (-)-Dihydrovertinolide<smiles>C=C1C(=O)O[C@H]2[C@@H](CC)OC(=O)[C@H]12</smiles>

139. Xylobovide

Figure 14. Structures of the phytotoxic furan and furanone analogures isolated from fungi.

Penicillic acid (129) from Malbranchea aurantiaca showed significant inhibition of radicle growth of Amaranthus hypochondriacus seedlings with $\mathrm{IC}_{50}$ value of $3.86 \mu \mathrm{M}$ [111].

Quercilactone A (130) was isolated from Raffaelea quercivora, the pathogen of Japanese oak wilt disease. This compound exhibited weak phytotoxic activity by inhibiting root growth of lettuce seedlings [66].

Sapinofuranones A (131) and B (132), belonging to 5-substituted dihydrofuranones, were isolated from liquid cultures of Sphaeropsis sapinea, the pathogen to cause a wide range of disease symptoms on conifers such as Cupressus macrocarpa and C. sempervirens. Both metabolites were diastereomers of each other. Bioassay of sapinofuranones A (131) and B (132) gave epinasty and brown discoloration on petioles of tomato leaves, sapwood stain on inner cortical tissues of the stem of cypress seedlings, and yellowing and needle blight on pine seedlings [112].

Seiridin (133) and isoseiridin (135), belonging to $\Delta \alpha, \beta$-butenolides, were produced by the cultures of Seiridium cardinal, S. cupressi, and S. unicorne. Seiridin (133) showed inhibition on lettuce germination, and isoseiridin (135) did not [113]. $7^{\prime}$-Hydroxyseiridin (134) and $7^{\prime}$-hydroxyisoseiridin (136) were also isolated from the cultures of Seiridium cardinal, S. cupressi, and S. unicorne. Both hydroxylation products of seiridin (133) and isoseiridin (135) produced necrotic and chlorotic symptoms on the cuttings of host plants (Cupressus sempervirens var. pyramidalis, C. arizonica, and C. macrocarpa) and non-host plants (Lycopersicon esculentum and Phaeolus valgaris var. arueus) [114].

Terrestric acid (137) was isolated from the culture broth of Magnaporthe oryzae (anamorph: Pyricularia oryza). It inhibited root and leaf growth of rice seedlings at $300 \mu \mathrm{g} / \mathrm{mL}$ [115].

(-)-Dihydrovertinolide (138) belonged to $\alpha$-furanone isolated from Clonostachys rosea B5-2. This compound displayed phytotoxic activity against lettuce seedlings at concentration of $50 \mu \mathrm{g} / \mathrm{mL}$ [116].

Xylobovide (139) was isolated from the culture broth of Xylaria obovata. This metabolite inhibited seed germination of Eragrostis tef at 50-100 $\mu \mathrm{g} / \mathrm{mL}$ [117]. 


\subsubsection{Aromatic-Free Pyrones}

Phytotoxic aromatic-free pyrones include $\alpha$-pyrones and $\gamma$-pyrones. Most of them belong to $\alpha$-pyrones. The structures of phytotoxic aromatic-free $\alpha$-pyrones from fungi are shown in Figure 15. ACRL toxins I (140), II (141), III (142), IV (143), and IV' (144) were isolated from the culture broth of Alternaria citri, the fungal pathogen causing brown spot disease of rough lemon (Citrus jambhiri) and Rangpur Lime (Citrus limonia). They were toxic to the host plants rough lemon and Rangpur Lime by leaf puncture assay and electrolyte leakage assay. These ACRL toxins were considered as the host-specific phytotoxins $[118,119]$.<smiles>C/C=C(\C)C(O)C(C)/C=C/C(O)C(C)C(O)CC1CC(O)=CC(=O)O1</smiles>

140. ACRL toxin I<smiles>C/C=C(\C)C(O)C(C)/C=C/C(O)C(C)c1cc(O)cc(=O)o1</smiles>

141. ACRL toxin II<smiles>C/C=C(\C)C(O)C(C)/C=C/C(O)C(C)C(O)Cc1cc(O)cc(=O)o1</smiles>

142. ACRL toxin III<smiles>[R]C(C(O)C=CC(C)C(O)C(C)=CC)C(O)CC(O)Cc1cc(O)cc(=O)o1</smiles>

143. $A C R L$ toxin IV, $\mathrm{R}=\mathrm{CH}_{3}$

144. $A C R L$ toxin IV', $\mathrm{R}=\mathrm{H}$<smiles>C=C(C/C=C/[C@@](O)(C(=O)O)[C@@H](O)[C@H](C)CC)CCC(=O)C1=C(O)CC(C)OC1=O</smiles>

145. Alternaric acid<smiles>Cc1oc(=O)c(Cc2c(O)c(C)c(C)oc2=O)c(O)c1C</smiles>

146. Colletopyrone<smiles>C[C@H](O)[C@H]1C=C[C@@H]2OC(=O)C=C[C@H]2O1</smiles>

147. Diplopyrone<smiles>CCCCC[C@H]1C[C@@H](O)CC(=O)O1</smiles>

148. 3-Ethyl-4-hydroxy-6-methyl$2 H$-pyran-2-one<smiles>COc1cc(=O)oc(C(C)[C@H](C)O)c1C</smiles>

149. Gulypyrone A<smiles>[R]C(CCCC)c1cc(OC)cc(=O)o1</smiles>

150. 6-(1-Hydroxypentyl-4-methoxy-pyran-2-one, $\mathrm{R}=\mathrm{OH}$ 151. 6-Pentyl-4-methoxy-pyran-2-one, $\mathrm{R}=\mathrm{H}$<smiles>CC=C(C)c1cc(OC)cc(=O)o1</smiles>

152. Pestalopyrone<smiles>C/C=C(C)/C=C(\C)c1cc(OC)c(C)c(=O)o1</smiles>

153. Phomenin A<smiles>C/C=C(/C)C=C(C)c1cc(OC)c(C)c(=O)o1</smiles>

154. Phomenin $B$<smiles>COc1cc([C@H]2[C@H](C)C=C[C@H]3CCCC[C@]23C)oc(=O)c1C=O</smiles>

160. Solanapyrone A 161 . Solanapyrone B

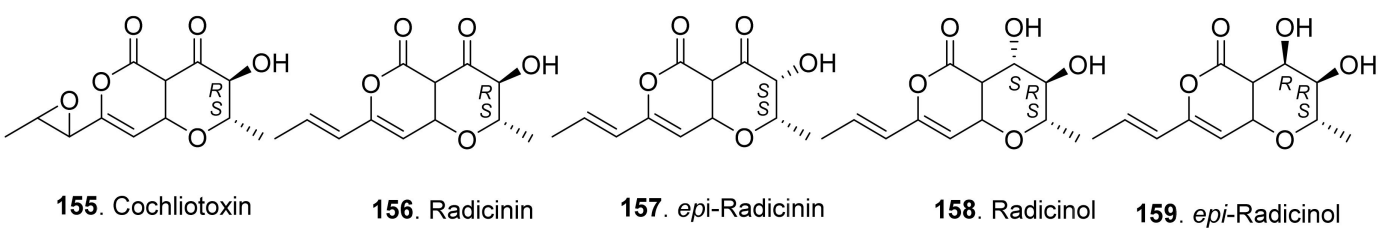

Figure 15. Structures of the phytotoxic aromatic-free $\alpha$-pyrones isolated from fungi. 
Alternaric acid (145) was isolated from the culture filtrates of Alternaria solani, the pathogen of early blight and collar rot diseases on tomato plants. Alternaric acid (145) was toxic to tomato seedlings [120].

Colletopyrone (146) was isolated from Colletotrichum nicotianae. This compound caused brown necrotic spots on young tobacco leaves [121].

Simple $\alpha$-pyrones are often lactone derivatives of fatty acids. Diplopyrone (147) was a phytotoxic metabolite of Diplodia corticola [122] and Diplodia mutila [123], which were phytopathopagenic fungi causing different forms of cork oak canker on Quercus suber with heavy economic losses. Diplopyrone (147) was toxic to the cuttings of cork oak and tomato by causing necrosis and wilting. The absolute configuration of diplopyrone (147) was determined by vis-à-vis comparison of experimental and simulated spectra [124].

Further, 3-ethyl-4-hydroxy-6-methyl-2H-pyran-2-one (148) isolated from Raffaelea quercivora, the pathogen of Japanese oak wilt disease, had weak phytotoxic activity by inhibiting root growth of lettuce seedlings [66].

Gulypyrone A (149) from Diapothe gulyae, the pathogen of sunflower (Helianthus annuus), caused leaf necrosis on sunflower plantlets [125].

Then, 6-(1-hydroxypentyl)-4-methoxypyran-2-one (150), 6-pentyl-4-methoxy-pyran-2one (151) and pestalopyrone (152) were isolated for Pestalotiopsis guepinii. They all showed phytotoxic activity on some non-host plants (i.e., Convolvulus arvensis, Mercurialis annua, Chenopodium album and Ailanthus altissima) by leaf puncture assay [126].

Pestalopyrone (152) was a pentaketide phytotoxin isolated from Pestalotiopsis guipinii, the pathogen to cause twig of hazelnut (Corylus avellana). This compound was toxic to a few non-host plants such as Cirsium arvense, Sonchus oleraceus, and Chenopodium album by causing extensive necrosis on the test plant leaves [127].

Phomenins A (153) and B (154) were polypropionate $\alpha$-pyrones produced by Phoma tracheiphila, the pathogen of the destructive disease of lemon groves in the Mediterranean area. Only phomenin A (153) showed phytotoxicity on tomato cutting while both phomenins A (153) and B (154) exhibited zootoxcity against brine shirimp (Artemia salina L.) larvae [128].

Radicinin (156), radicinol (158) and epi-radicinol (159) were isolated from cultures of Alternaria radicina grown on carrot slices. Both radicinin (156) and epi-radicinol (159) reduced root elongation of germinating carrot seeds [129]. Five phytotoxic radicinin derivatives named cochliotoxin (155), radicinin (156), epi-radicinin (157), radicinol (158), and epi-radicinol (159) were also isolated from the liquid culture of Cochiliobolus australiensis, the foliar pathogen of buffelgrass (Pennisetum ciliaris). The phytotoxic metabolites could potentially be used as natural herbicides in an integrated pest management strategy against the weed buffelgrass [130]. In addition, radicinin (156) was isolated from Curvularia sp. FH01 as the endophytic fungus in the gut of Atractomorpha sinensis. This compound exhibited significant phytotoxic activity against the radical growth of Echinochloa crusgalli [131]. Radicinin (156) was also isolated from Fusarium proliferatum ZS07, the fungus residing in the gut of long-horned grasshopper (Tettigonia chinensis). It showed inhibitory activity on the radicle growth of Amaranthus retrofleus seedlings at $100 \mu \mathrm{g} / \mathrm{mL}$ [22].

Solanapyrones A (160) and B (161) were isolated from the culture filtrates of Alternaria solani, the causal organism of early blight disease of tomato and potato. Both metabolites induced leaf necrotic lesion of the host plants [132]. Solanapyrone A (160) was later isolated from the culture filtrates of Ascochyta rabiei grown in the Czapek-Dox medium supplemented with seed aqueous extract of host plant chickpea. Solanapyrone A (160) was toxic to the cultured cells of chickpea [133].

Three phytotoxic aromatic-free $\gamma$-pyrones (Figure 16) namely spiciferones A (162), B (163) and C (164) were isolated from the fungus Cochliobolus spicifer. Among them, spiciferone A (162) was the most toxic to wheat cotyledon protoplasts, spiciferone C (164) was the least, and spiciferone B (163) had no activity. This indicated that the substitution on the $\gamma$-pyrone ring of spiciferone A (162) affected its phytotoxicity, and the methyl at C-2 was also essential to its phytotoxicity [134,135]. 
<smiles>[R]Cc1oc2c(c(=O)c1C[R])C=CC(=O)[C@@]2(C)CC</smiles>

162. Spiciferone $A, R_{1}=H, R_{2}=H$

163. Spiciferone $B, R_{1}=O H, R_{2}=H$

164. Spiciferone $C, R_{1}=H, R_{2}=O H$

Figure 16. Structures of the phytotoxic aromatic-free $\gamma$-pyrones isolated from fungi.

\subsubsection{Furopyran and Pyranopyran Analogues}

Phytotoxic furanpyran and pyranpyran analogues from fungi with their structures are shown in in Figure 17. Three dihydrofuropyran-2-ones afritoxinones A (165) and B (166), and oxysporone (167) were isolated from Diplodia africana, the causal agent of branch dieback on Juniperus phoenicea. Three compounds showed phytotoxic activity on host (Phoenicean juniper) and non-host plants (holm oak, cork oak and tomato) by cutting and leaf puncture assays. Among them, oxysporone (167) was the most phytotoxic compound [136].<smiles>CO[C@H]1C=C[C@@H]2CC(=O)O[C@H]2O1</smiles>

165. Afritoxinone A<smiles>CO[C@H]1C=C[C@@H]2CC(=O)O[C@H]2O1</smiles>

166. Afritoxinone B<smiles>O=C1C[C@H]2OC=C[C@@H](O)[C@H]2O1</smiles>

167. Oxysporone<smiles>C/C=C(\OC)C(=O)[C@H]1OC2O[C@@H](C(=O)/C(=C/C)OC)C(C)=C(C)C2C(C)=C1C</smiles>

168. Biscopyran<smiles>COC1=C(C)O[C@@H]2OC(C)=CC(/C(C)=C/CO)=C12</smiles>

169. Chenopodolan D<smiles>COC1=CC(=O)O[C@H]2OC[C@H](C)[C@H]12</smiles>

170. Luteopyroxin

Figure 17. Structures of the phytotoxic furopyran and pyranpyran analogues isolated from fungi.

Biscopyran (168) was a phytotoxic hexasubstituted pyranopyran isolated from the liquid culture filtrates of Biscogniauxia mediterranea, the pathogen of cork oak (Quercus suber). This compound caused epinasty on cork oak cuttings, and wilting on non-host tomato [137].

Chenopodolan D (169) was isolated from Phoma chenopodiicola, the pathogen of Chenopodium album. Chenopodolan D (169) was toxic to six weedy plants, namely Stellaria media, Urtica dioica, Sonchus arvensis, Parietaria officinalis, Lactuca serriola, and Helianthus annuus by leaf puncture assay [138].

Luteopyroxin (170) was isolated from Neofusicoccum luteum, the causal agent of Botryosphaeria dieback in Australia. This compound showed the phytotoxic effect by causing severe shriveling and withering on grapevine by leaf assay [37].

\subsubsection{Macrolide Analogues}

Phytotoxic aromatic-free macrolides from fungi with their structures are shown in Figure 18. Brefeldin A (171) was a bicyclic lactone isolated from the culture filtrates of 
Alternaria zinnia, which was used as the biocontrol agent of Xanthium occidentale (Compositae). Brefeldin A (171) was toxic to a series of the tested plants such as Chenopodium album, Cirsium arvense, Mercurialis annua, Nicotiana tabacum, Sonchus oleraceus, and Xanthium occidentale at $10^{-4} \mathrm{M}$ by leaf pucture assay [101].

$\mathrm{HO}$<smiles>C[C@H](O)/C=C/C(=O)O[C@@H](C)CCC/C=C/[C@H]1CCC[C@@H]1O</smiles>

171. Brefeldin A<smiles>[R]C(=O)O[C@H](CCC)C([R])/C=C/CCC([R])C([R3])C</smiles>

175. Herarumin I, $\mathrm{R}_{1}=\beta \mathrm{OH}, \mathrm{R}_{2}=\mathrm{H}, \mathrm{R}_{3}=\beta \mathrm{OH}$ 176. Herarumin II, $\mathrm{R}_{1}=\beta \mathrm{OH}, \mathrm{R}_{2}=\beta \mathrm{OH}, \mathrm{R}_{3}=\beta \mathrm{OH}$ 177. 2-epi-Herbarumin II, $\mathrm{R}_{1}=\alpha \mathrm{OH}, \mathrm{R}_{2}=\beta \mathrm{OH}, \mathrm{R}_{3}=\beta \mathrm{OH}$ 178. Herbarumin III, $\mathrm{R}_{1}=\mathrm{H}, \mathrm{R}_{2}=\mathrm{H}, \mathrm{R}_{3}=\beta \mathrm{OH}$ 182. Pinolide, $\mathrm{R}_{1}=\alpha \mathrm{OH}, \mathrm{R}_{2}=\alpha \mathrm{OH}, \mathrm{R}_{3}=\beta \mathrm{OH}$<smiles>[R]C1CCC[C@@H](O)[C@@H](O)/C=C\C(=O)O[C@@H](C)C1</smiles><smiles>C[C@H]1CCCCC[C@@H](O)[C@@H](O)/C=C\C(=O)O1</smiles>

173. Cladospolide $B, \mathrm{R}=\mathrm{H}$

180. Myxotrilactone $A, R=O H \quad$ 174. Cladospolide $C$

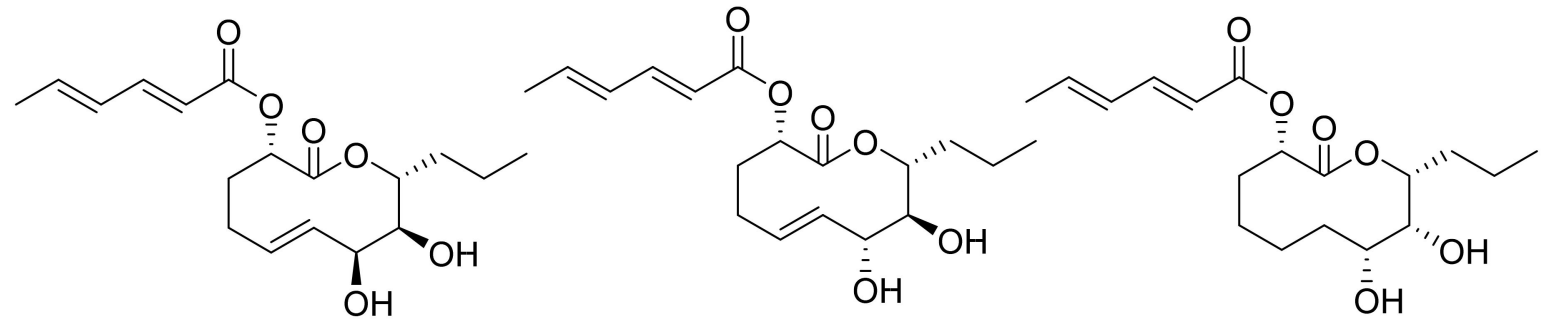

183. Pinolidoxin<smiles>COC1=CC(=O)OCC(C)=C1CO</smiles><smiles>CCC[C@H](C[C@@H](O)[C@@H](O)/C=C/CCC(=O)O)OC</smiles>

179. Luteoxepinone

181. (6S,7R,9R)-6,7-Dihydroxy-9propylnon-4-eno-9-lactone

185. 5,6-Dihydropinolidoxin<smiles>C/C=C/C=C/C(=O)O[C@H]1CCC2OC2C(=O)O[C@H](CCC)[C@@H](O)[C@@H]1O</smiles>

186. 5,6-Epoxy-pinolidoxin<smiles>CCC[C@@H]1/C=C\C(O)CCCC(=O)O1</smiles>

187. Putaminoxin<smiles>CCC/C1=C/C(O)C(=O)CCCCC1=O</smiles>

188. Putaminoxin $C$<smiles>COC(=O)/C=C/C(=O)CCC(C)OC(=O)/C=C/C(=O)CCC(C)C</smiles>

189. Pyrenophorin<smiles>COC(=O)/C=C/C(=O)CCC(C)OC(=O)/C=C/C(O)CCC(C)C</smiles>

190. (-)-Dihydropyrenophorin<smiles>COC(=O)C=CC(O)CCC(C)OC(=O)C=CC(O)CCC(C)OC</smiles>

191. Pyrenophorol<smiles>C[C@H]1CCC/C=C\[C@@H](O)[C@H]2O[C@H]2[C@@H]1O</smiles>

192. Seiricuprolide

Figure 18. Structures of the phytotoxic aromatic-free macrolides isolated from fungi. 
Cladospolides A (172) and B (173) were isomers isolated from the culture broth of Cladosporium cladosporioides. Cladospolide A (172) inhibited root elongation of lettuce and rice seedlings. However, cladospolide B (173) promoted root elongation of lettuce seedlings. It was interesting that these isomers had different plant growth regulatory activities [139]. Cladospolide C (174), a diastereomer of cladospolide A (172), was isolated from the culture filtrate of Cladosporium tenuissimum. Cladospolide C (174) inhibited shoot elongation of rice seedlings [140].

Cladospolide B (173) and myxotrilactone A (180) were isolated from the solid-substrate cultures of the endolichenic fungus Myxotrichum sp. Both compounds significantly inhibited shoot elongation of Arabibopsis thaliana by seedling growth assay [141].

Three nonenolides, namely herbarumins I (175), II (176), and III (178), were isolated from Phoma herbarum. These three compounds caused significant inhibition on radicle growth of Amaranthus hypochondriacus seedlings [142,143]. Both herbarumin II (176) and 2-epi-herbarumin II (177) were isolated from Ascochyta pinodes (syn. Dymidella pinodes), the pathogen of Ascochyta blight disease. These two compounds were toxic to Pisum sativum by leaf puncture assay [144].

Luteoxepinone (179) was isolated from Neofusicoccum luteum, the causal agent of Botryosphaeria dieback in Australia. It showed the phytotoxic effect by causing severe shriveling and withering on grapevine by leaf assay [37].

$(6 S, 7 R, 9 R)-6,7-D i h y d r o x y-9-p r o p y l n o n-4-e n o-9-l a c t o n e ~(181)$ was a phytotoxic nonenolide isolated from the solid cultures of endophytic fungus Phomopsis sp. HCCB03520 associated from Achyranthes bidentata. This metabolite showed phytotoxic activity on germination and radicle growth of Medicago sativa, Trifolium hydridum, and Buchloe dactyloides [145].

Pinolide (182) was isolated from Ascochyta pinodes (syn. Dymidella pinodes). This compound was toxic to Pisum sativum by leaf puncture assay [144].

Four nonenolide analogs called pinolidoxin (183), 7-epi-pinolidoxin (184), 5,6-dihydropinolidoxin (185), and 5,6-epoxy-pinolidoxin (186) were isolated from Ascochyta pinodes, the causal agent of anthracnose of pea (Pisum sativum). They caused necrotic lesions on pea and bean leaves tested by leaf puncture assay [146,147].

Putaminoxin (187) was isolated from the liquid culture filtrates of Phoma putaminum, the causal agent of leaf necrosis of Erigeron annuus. Putaminoxin (187) was toxic to a wide range of host and non-host plants with leaves of E. annuus being most sensitive [148]. Putaminoxin C (188) was isolated from the liquid culture filtrates of Phoma putaminum. This compound showed toxic effects similar to putamnoxin (187) [149].

Pyrenophorin (189) was isolated from the cultures of Pyrenophora avenae. It depressed radical growth of oat (Avena sativa) seedlings [150]. (-)-Dihydropyrenophorin (190) was isolated from the liquid culture of Drechslera avenae, the causal agent of leaf blotch of oats. This compound caused sunken lesions on oats and a variety of other plants at $3.2 \times 10^{-4} \mathrm{M}$ [151]. Pyrenophorol (191) was later isolated from $D$. avenae and was toxic to oats [152].

Seiricuprolide (192) was isolated from Seiridium sp., the pathogen causing canker disease of cypress. It showed minor inhibition to the test plants by cutting assay [153].

\subsubsection{Sorbicillinoids}

Sorbicillinoids (also called vertinoids) belong to hexaketide metabolites in which the cyclization has taken place on the carboxylate terminus. They have a variety of biological activities including cytotoxic, antioxidant, antiviral, antimicrobial and phytotoxic activity $[154,155]$. Four phytotoxic sorbicillinoids (Figure 19) named bisvertinolone (193), demethyltrichodimerol (194), trichodimerol (195), and trichotetronine (also called bislongiqinolide 196) were isolated from the rice solid cultures of Ustilaginoidea virens (teleomorph: Villosiclava virens), the pathogen of rice false smut disease. These compounds were evaluated for their phytotoxic activity, and showed strong inhibition against the radicle and germ elongation of rice and lettuce seedlings. Among these compounds, bisvertinolone (193) displayed the strongest inhibition [156]. 


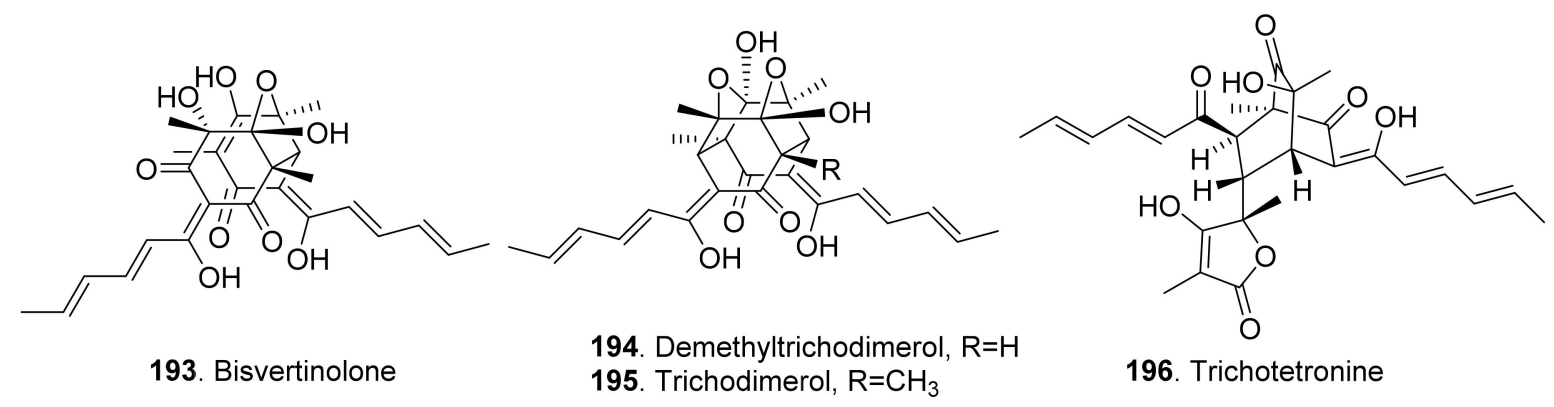

Figure 19. Structures of the phytotoxic sorbicillinoids isolated from fungi.

\subsubsection{Linear Polyketides}

The structures of phytotoxic linear polyketides from fungi are shown in Figure 20. Three AF-toxins have been reported as AF-toxins I (197), II (198), and III (199), which were produced by Alternaria alternata, the pathogen of black spot of strawberry. They were host-specific toxins. AF-toxin I (197) also showed toxicity towards pear. AF toxin III (199) was highly toxic towards strawberry and less toxic to pear, while AF-toxin II (198) was toxic to pear $[4,157]$.

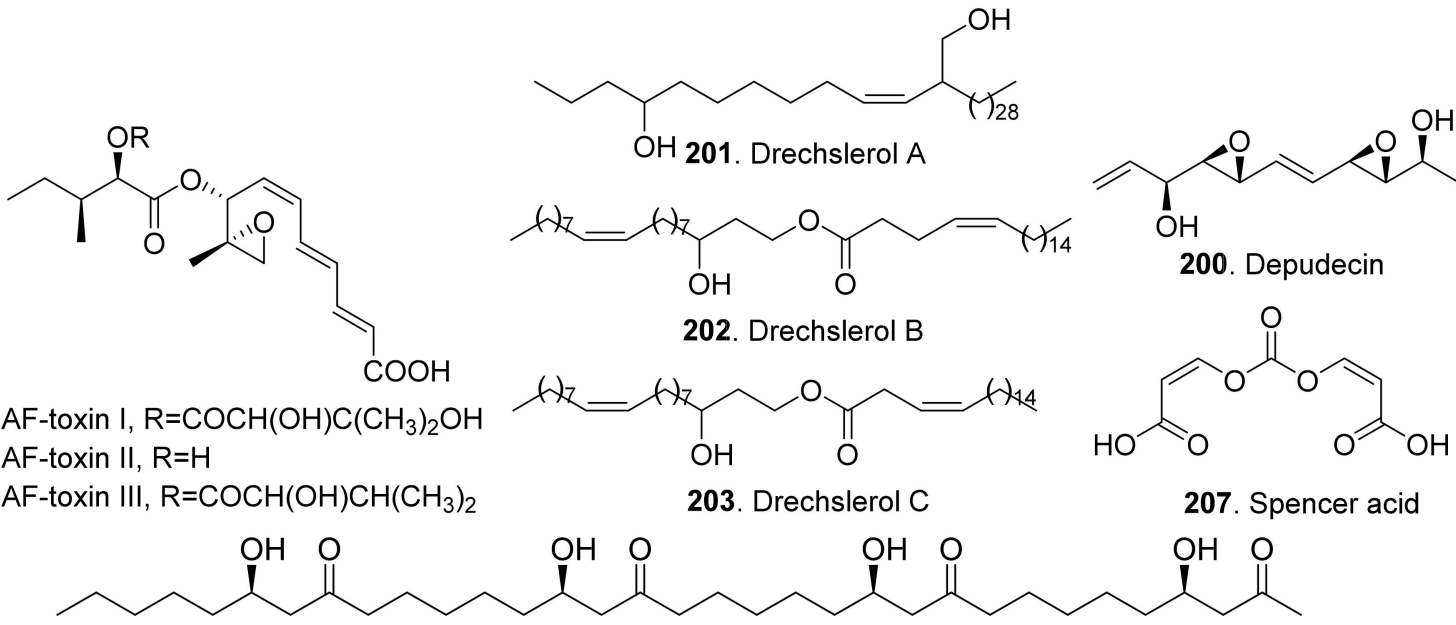

204. PM-toxin A

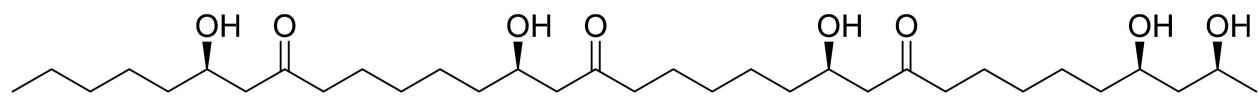

205. PM-toxin B<smiles>CCCCCC(O)CC(=O)CCCCCC(O)CC(=O)CCCCCC(O)CC(=O)CCCCCC(O)CC(O)CC(C)O</smiles>

206. PM-toxin C

Figure 20. Structures of the phytotoxic linear polyketides isolated from fungi.

Depudecin (200) was isolated from the weed pathogen Nimbya scirpicola. This metabolite produced necrotic lesions on kuroguwai, cowpea, and kidney bean by leaf-puncture assay, and inhibited the root elongation of lettuce seedlings. It did not show significant effects on the other test plants, which indicated that depudecin (200) was a host specific toxin [158].

Three host-specific toxins namely drechslerols A (201), B (202), and C (203) were successively isolated from the culture filtrate of Drechslera maydis, the pathogen of leaf 
blight disease of Costus speciosus. They all caused necrotic and chlorotic lessions on the leaves of C. speciosus, and inhibited root growth of wheat seedlings [159-161].

Three host-specific toxins namely PM-toxins A (204), B (205), and C (206) were isolated from the corn pathogen Phyllosticta maydis. They belonged to the linear polyketides with phytotoxicity toward the tissues and mitochondria obtained from susceptible corn varieties [162].

Spencer acid (207) was a diacrylic acid derivative isolated from Spencermartinsia viticola, the causal agent of Botryosphaeria dieback on grapevine in Australia. It exhibited strong phytotoxicity on Vitis lambrausca and V. vinifera cv. Shiraz by grapevine leaf assay [163].

\section{Phenols and Phenolic Acids}

Phenols and phenolic acids are mixed biosynthetic origins. Most phenol and phenolc acid derivatives are of polyketide origin such as salicylaldehyde analogues. Other biosynthetic origins include shikimic acid and mevalonic acid pathways [164]. The structures of phytotoxic phenols and phenolic acids from fungi are shown in Figure 21.

Agropyrenol (208) was a dihydroxypentenyl substituted salicyladehyde isolated from the liquid cultures of Ascochyta agropyrina var. nana. When the leaves of several weed plants (i.e., Mercurialis annua, Chenopodium album, and Setaria viridis) were assayed, agropyrenol (208) was proved to be phytotoxic to cause the appearance of necrotic lesions by leaf puncture assay [57].

Ascosalitoxin (209) was a trisubstituted salicylic aldehyde which belonged to the methylated hexaketide via polyketide biosynthetic pathway [165]. This metabolite was isolated from Ascochyta pisi var. pisi to show phytotoxic activities on the leaves and pods of pea and bean, as well as on tomato seedlings [166].<smiles>C[C@H](O)[C@@H](O)/C=C/c1cccc(O)c1C=O</smiles>

208. Agropyrenol<smiles>CC[C@H](C)C(=O)[C@H](C)c1cc(O)c(C)c(O)c1C=O</smiles>

209. Ascosalitoxin<smiles>Cc1cc(O)c(C)c(O)c1C=O</smiles>

210. 2,4-Dihydroxy-3,6-dimethylbenzaldehyde<smiles>O=Cc1ccc(O)cc1</smiles>

211. $p$-Hydroxybenzaldehyde<smiles>Oc1ccc(O)c(O)c1</smiles>

212. Benzene-1,2,4-triol

213.<smiles>O=C(O)c1ccc(O)cc1</smiles>

13. p-Hydroxybenzoic acid<smiles>CC=CC=CC1OCc2c(O)cccc2C1O</smiles>

214. 3-(1',3'-Pentadienyl)-3,4-dihydro1 H-2-benzopyran-4,8-diol<smiles>C/C(=C\Cc1c(O)c(Cl)c(C)c(C=O)c1O)CCC(O)C(C)(C)O</smiles>

217. Colletochlorin A
215. 4-(1'-Hydroxy-2'-butenyl)-1,4dihydro-2,3-benzodioxocin-10-ol<smiles>CCC/C=C/C=C/C(=O)c1c(OC)cc(CO)c(C(=O)O)c1O</smiles>

216. Cavoxin

Figure 21. Cont. 
<smiles>Cc1oc(=O)c(Cc2c(C)c(Cl)c3c(c2O)C[C@H](C(C)(C)O)O3)c(C)c1C</smiles>

218. Colletochlorin E<smiles>Cc1cc(O)c2c(c1Cl)O[C@H](C(C)(C)O)C2</smiles>

219. Colletochlorin $F$<smiles>[R]c1ccc(C[C@@H](O)C(=O)OC)cc1</smiles>

220. Crypticin $A, R=H$ 221. Crypticin $B, R=O H$<smiles>[R]OC(=O)Cc1cc(O[R])cc(O)c1C(C)=O</smiles>

222. Curvulin, $\mathrm{R}_{1}=\mathrm{H}, \mathrm{R}_{2}=\mathrm{CH}_{2} \mathrm{CH}_{3}$

223. O-Methylcurvulinic acid, $\mathrm{R}_{1}=\mathrm{CH}_{3}, \mathrm{R}_{2}=\mathrm{H}$
224. Diorcinol<smiles>Cc1cc(O)cc(Oc2cc(C)cc(O)c2)c1</smiles><smiles>CCOC(=O)c1c(O)cc(O)cc1CCCCCCCC(C)O</smiles>

225. Ethyl(S)-2,4-dihydroxy-6(8-hydroxynonyl) benzoate<smiles>CCOC(=O)c1c(O)cc(O)cc1CCCCCCO</smiles>

226. Ethyl 2,4-dihydroxy-6(8-hydroxyheptyl) benzoate<smiles>CCOC(=O)c1c(O)cc(O)cc1CCCCC(=O)OC</smiles>

227. Ethyl 2,4-dihydroxy-6-(4-methoxy carbonylbutyl) benzoate<smiles>CC(C)COC(=O)c1c(O)cc(O)cc1CCCCCCC(C)O</smiles>

228. Isobutyl (S)-2,4-dihydroxy-6(8-hydroxynonyl) benzoate<smiles>CCOC(=O)c1c(O)cc(O)cc1CCCCCCC(C)=O</smiles>

229. Ethyl 2,4-dihydroxy-6-(8-oxononyl) benzoate<smiles>COc1c(C)cc(CO)c2c1C(=O)OC2O</smiles>

230. Dihydrogladiolic acid<smiles>[R]C([R])[C@H](O)Cc1ccc(O)cc1</smiles>

231. Lathyroxin $A, R_{1}=\mathrm{OCH}_{3}, \mathrm{R}_{2}=\mathrm{OCH}_{3}$ 232. Lathyroxin $B, \mathrm{R}_{1}=\mathrm{H}, \mathrm{R}_{2}=\mathrm{OH}$<smiles>Cc1cc(O)cc(O)c1Cl</smiles><smiles>OCc1cccc(O)c1</smiles><smiles>COc1ccc(O)cc1</smiles><smiles>O=C(O)Cc1ccc(O)cc1</smiles>

233. 4-Chloroorcinol<smiles>Cc1cc(O)cc(O)c1C(=O)O[C@H](C)[C@](C)(O)C(=O)O</smiles>

237. Phomozin<smiles>[R]OCc1ccc(O[R2])c(O[R])c1</smiles>

238. Protocatechuic alcohol, $\mathrm{R}_{1}=\mathrm{H}, \mathrm{R}_{2}=\mathrm{H}, \mathrm{R}_{3}=\mathrm{H}$

239. Protocatechuic alcohol isopropyl ether, $R_{1}=H, R_{2}=A c, R_{3}=H$

240. Triacetyl protocatechuic alcohol, $R_{1}=A c, R_{2}=A c, R_{3}=A c$

Figure 21. Cont. 
<smiles>[R]c1c(O)cccc1/C=C/C=C/C(O)C(C)O</smiles>

241. Pyriculariol, $\mathrm{R}=\mathrm{CHO}$

242. Dihydropyriculariol, $\mathrm{R}=\mathrm{CH}_{2} \mathrm{OH}$<smiles>C/C=C/C(=O)C(=O)/C=C/c1cccc(O)c1C=O</smiles><smiles>[R]c1c(O)cccc1/C=C/[C@@H](O)[C@H](O)/C=C/C</smiles>

244. Pyriculol, $\mathrm{R}=\mathrm{CHO}$

245. Dihydropyriculol, $\mathrm{R}=\mathrm{CH}_{2} \mathrm{OH}$<smiles>C/C=C/[C@H](O)[C@@H](O)/C=C/c1cccc(O)c1C=O</smiles>

246. Epipyriculol<smiles>C/C=C/[C@H](/C=C/c1cccc(O)c1C=O)CO</smiles>

247. Pyricuol<smiles>Oc1cccc(O)c1</smiles>

248. Resorcinol<smiles>CCCCCc1cc(O)c(CCCC)c(O)c1</smiles>

249. Stemphol<smiles>OCCc1ccc(O)cc1</smiles>

250. Tyroso<smiles>COc1c(C)c(CO)cc(OCC=C(C)C)c1C</smiles>

251. Zinniol<smiles>COc1c(C)c(OCC(O)C(C)(C)O)cc(CO)c1CO</smiles>

252. Zinnidiol<smiles>COc1c(C)c(O)cc(CO)c1CO</smiles>

253. Zinnol

Figure 21. Structures of the phytotoxic phenols and phenolic acids isolated from fungi.

Moreover, 2,4-dihydroxy-3,6-dimethylbenzaldehyde (210) isolated from Leptosphaeria maculans was virulent on canola. This metabolite had strong root and hypocotyl growth inhibition on lettuce seedlings [167].

p-Hydroxybenzaldehyde (211) was isolated from Ascochyta lentis var. lathyri, the pathogen of grapevine trunk. This compound caused necrosis on leaves of seven plant species by leaf puncture assay, and inhibited seed germination and rootlet elongation of Phelipanche ramose [18]

Six phenols, namely benzene-1,2,4-triol (212), 3-(hydroxymethyl)phenol (234), protocatechuic alcohol (238), protocatechuic alcohol isopropyl ether (239), triacetyl protocatechuic alcohol (240), and resorcinol (248), were isolated from Dothiorella viidmadera, the causal agent of grapevine trunk desease. They all showed phytotoxicity to tomato and grapevine. Among them, resorcinol (248) was the most phytotoxic compound on grapevine leaves by causing severe shriveling of the leaves [168].

$p$-Hydroxybenzoic acid (213) was isolated from Alternaria dauci, which was the causal agent of Alternaria leaf blight. It showed an important phytotoxic activity when tested in the leaf-spot assay on parsley (Petroselinum crispum), in the leaf infiltration assay on tobacco (Nicotiana alata) and marigold (Tagetes erecta), and in the immersion assay on parsley and parsnip (Pastinaca sativa) leaves. It might play an important role in the pathogenicity of the fungus [169].

Two phenolic acids namely $p$-hydroxybenzoic acid (213) and 4-hydroxyphenylacetic acid (236) were isolated from Spencermartinsia viticola, the causal agent of Botryosphaeria dieback on grapevine in Australia. Both metabolites showed strong phytotoxicity on Vitis lambrausca and Vitis vinifera cv. Shiraz by grapevine leaf assay [163].

Two pyriculol-related phytotoxins named 3-(1',3'-pentadienyl)-3,4-dihydro-1H-2benzopyran-4,8-diol (214) and 4-(1'-hydroxy-2'-butenyl)-1,4-dihydro-2,3-benzodioxocin10-ol (215) were isolated from solid cultures of Pyricularia oryzae. Both compounds gave a yellowish-orange symptom to rice leaves by leaf puncture assay [170]. 
Cavoxin (216) was a tetrasubstituted benzoic acid derivative isolated from Phoma cava, the pathogen of chestnut (Castanea spp.). Cavoxin (216) caused vascular browning and rapid wilting of the leaflets by tomato cutting assay [171].

Colletochlorins A (217), E (218), and F (219) were isolated from Colletotrichum higginsianum. Colletochlorin A (217) was a chlorinated 3-diprenyl orsellinaldehyde derivative. Colletochlorin F (219) was a dihydrobenzofuran. Colletochlorin E (218) was considered to be the combination of a tetrasubstituted $\alpha$-pyranone with colletochlorin F (219). Among three compounds, collethochlorin F (219) caused the fastest appearance of quite large necrosis on punctured Sonchus arvensis leaves. Tomato punctured leaves were less sensitive to these compounds by comparing with $S$. arvensis leaves [172].

Crypticins A (220) and B (221) were isolated from the culture filtrates of Diaporthella cryptica, the emerging hazelnut pathogen [173].

Curvulin (222) and O-methylcurvulinic acid (223) were isolated from Drechslera indica which caused leaf necroses on purslane (Portulaca oleracea) and spiny amaranth (Amaranthus spinosus). Curvulin (222) was only toxic to the host plants purslane and spiny amaranth. O-Methylcurvulinic acid (223) was also toxic to the other test plant species besides host plants [174].

Diorcinol (or called 3,3'-dihydroxy-5, $5^{\prime}$-dimethyldiphenyl ether, 224) was isolated from Diplodia corticola, an oak pathogen. This metabolite was toxic to the leaves of Quercus afares, $Q$. suber, $Q$. ilex and Celtis australis at $1 \mathrm{mg} / \mathrm{mL}$ by causing necrotic lesions [175]. Diorcinol (224) was also isolated from the endophytic fungus Epichloe bromicola obtained from Elymus tangutorum grass. It displayed obvious inhibition on the root and shoot growth of Lolium perenne and Poa crymophila seedlings, and was as active as the positive control glyphosate [176].

Five $\beta$-resorcylic acid derivatives namely ethyl (S)-2,4-dihydroxy-6-(8-hydroxynonyl) benzoate (225), ethyl 2,4-dihydroxy-6-(8-hydroxyheptyl) benzoate (226), ethyl 2,4-dihydroxy6-(4-methoxycarbonylbutyl) benzoate (227), isobutyl (S)-2,4-dihydroxy-6-(8-hydroxynonyl) benzoate (228), and ethyl 2,4-dihydroxy-6-(8-oxononyl) benzoate (229) were isolated from rice fermentation cultures of the endophytic fungus Lasiodiplodia theobromae derived from the mangrove plant Xylocarpus granatum. These metabolites all stimulated root elongation of Luctuca sativa seedlings. In addition, ethyl 2,4-dihydroxy-6-(4-methoxycarbonylbutyl) benzoate (227) inhibited root elongation of Digitaria ciliaris [104].

Dihydrogladiolic acid (230) was a tetrasubstitued benzofuranone isolated from Phoma asparagi. It showed inhibitory activity on root elongation of lettuce seedlings [177].

Lathyroxins A (231) and B (232) were two phytotoxic $p$-hydroxyphenylpropanoids isolated from Lathyroxin A (231) caused necrosis on leaves of Lupinis albus and Sonchus oleraceus. Lathyroxin B (232) caused clear necrosis on leaves of all the tested plants including Sonchus oleraceus, Lycopersicon esculentum, Phaseolus vulgaris, and Lens culinaris. Both compounds inhibited seed germination and rootlet elongation of the parasitic weed Phelipanche ramosa [178].

4-Chloroorcinol (233) was isolated Colletotrichum higginsianum. This compound caused necrosis on the punctured leaves of Sonchus arvensis and tomato leaves [172].

p-Methoxyphenol (235) was isolated from the culture filtrates of Ascochyta lentis var. lathyri, the causal agent of Ascochyta blight of grass pea (Lathyrus satious). $p$-Methoxyphenol (235) caused clear necrosis on leaves of seven test plants, and inhibited seed germination and rootlet elongation of the parasitic weed Phelipanche ramosa [178].

Phomozin (237) was an ester of orsellinic acid and dimethylglyceric acid. It was isolated from Phomopsis helianthi which was the causal agent of leaf necrosis and steam cankers of sunflowers. Phomozin (237) was thought as a host-specific phytotoxin by leaf puncture assay and cutting test [179].

Pyriculol (244) derivatives phytotoxins were mainly isolated from rice blast pathogen Magnaporthe oryzae (anamorph: Pyricularia oryzae) [180,181]. They are classified into two groups [181]: alcohol-type such as dihydropyriculariol (242) and dihydropyriculol (245), and aldehyde-type, such as pyriculariol (241) and pyriculol (244). Pyricuol (247) exhib- 
ited stronger phytotoxic activity toward rice than pyriculol (244) and dihydropyriculol (245) [182]. It has been shown that aldehyde derivatives induced lesion-like necrosis on rice leaves, while alcohol derivatives were inactive [183]. Epipyriculol (246) was isolated from the cultures of Pyricularia oryzae. It was the (10S)-isomer of pyriculol (244). Both pyriculol (244) and epipyriculol (246) caused a similar brownish symptom on the rice leaves by leaf puncture assay [170]. Dihydroxypyriculol (245) from Pyricularia grisea, the pathogen of buffelgrass (Cenchrus ciliaris), showed a significant stimulating effect of radical elongation of buffelgrass by seedling growth assay [32].

Stemphol (249) was isolated from Stemphylium botryosum, the pathogen of oilseed rape. This metabolite was toxic to the cells of oilseed rape and chickpea by using cell viability assay [184].

Phytotoxic tyrosol (also called 2-(4-hydroxyphenyl)-ethanol, 250) was isolated from a series of fungi such as Ascochyta lentis [87], Ascochyta lentis var. lathyri [178], Diaporthe eres [31], and Stilbocrea macrostoma [108].

Three phenol derivatives namely zinniol (251), zinnidiol (252) and zinnol (253) were isolated from the fungus Alternaria cichorii, the pathogen of foliar blight disease of Russian knapweed (Acroptilon repens). They were toxic to the leaves of Russian knapweed by in vitro leaf puncture assay [185]. Zinniol (251), which was also isolated from Alternaria solani, inhibited seedling growth of tomato [120].

\section{Terpenoids}

The phytotoxic terpenoids from fungi include monoterpenoids, sesquiterpenoids, diterpenoids, sesterterpenoids, triterpenoids, and meroterpenoids.

\subsection{Monoterpenoids}

Phytotoxic monoterpenoids from fungi with their structures are shown in Figure 22. The volatile and semi-volatile organic compounds with phytotoxic and antimicrobial activities were isolated from the endophytic fungus Hypoxy anthochroum strain Blaci isolated from Bursera lancifolia (Burseaceae). Eucalyptol (254), the main constituent among the volatile organic compounds, showed the highest phytotoxic effect on seed germination, root elongation and seedling respiration of Amaranthus hypochondriacus, Panicum miliaceum, Trifolium pratense, and Medicago sativa [186].

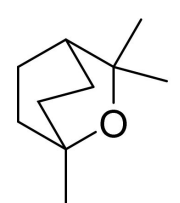

254. Eucalyptol<smiles>C/C=C(\C)c1cc(OC)c(C)c(=O)o1</smiles>

255. Nectriapyrone<smiles>CCC(C)c1cc(OC)c(C)c(=O)o1</smiles>

256. Methylphomapyrone $C$

Figure 22. Structures of the phytotoxic monoterpenoids isolated from fungi.

Nectriapyrone (255) was a monoterpenoid $\alpha$-pyrone from the pathogen Phomopsis foeniculi (teleomorph: Diaporthe angelicae) of fennel (Foeniculum vulgare). Nectriapyrone (255) showed a modulated phytotoxicity on the detached tomato leaves. Methylphomapyrone C (256) was the dihydroderivative of nectriapyrone (255) [75]. Both nectriapyrone (255) and methylphomapyrone C (256) were toxic to a number of non-host plants Cirsium arvense, Sonchus oleraceus, and Chenopodium album with a leaf puncture assay [127].

\subsection{Sesquiterpenoids}

Many sesquiterpenoids from fungi showed phytotoxic activities. Their structures are shown in Figure 23. Two drimane-type sesquiterpenoids, named altiloxins A (257) and B (258), were isolated as the main phytotoxins from Phoma asparagi, the causal agent of stem blight disease on saparagus. When tested on root elongation of the non-host lettuce 
seedlings, both compounds showed a weak inhibitory activity. Meanwhile, in the same assay carried out on the host plant at $10 \mu \mathrm{g} / \mathrm{mL}$, they inhibited the root elongation of $48.2 \%$ and $48.5 \%$, respectively [187].<smiles>[R]C1CC[C@]2(C)[C@@H](C(=O)O)[C@@](C)(O)C[C@@H]3O[C@]32C1(C)C</smiles><smiles>CC(C)=C1CCC23COC(O2)C1(O)CCC3C(=O)O</smiles>

259. Aspterric acid<smiles>C=C(C=O)C1(O)CC(C)(C)C(C)C(O)C=CC1=O</smiles>

260. Bipolaroxin<smiles>C=C(CO)C1(O)C[C@@]2(C)C(=CC1=O)C=C[C@H](O)[C@@H]2C</smiles>

261. Dihydrobipolaroxin

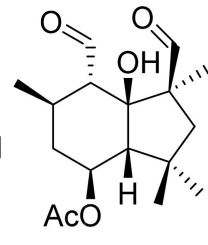

262. Botrydial

258. Altiloxin $B, R=C l$<smiles>CC(=O)OC1C[C@@H](C)[C@@H](C=O)[C@]2(O)[C@H](C)C[C@H](C)[C@]12O</smiles>

263.1-Epibotrydial<smiles>CC(=O)O[C@H]1C[C@@H](C)[C@@H](C=O)[C@]2(O)[C@](C)(C=O)CC(C)(C)[C@]12C</smiles>

264. 8,9-Epibotrydial<smiles>CC(=O)O[C@H]1C[C@@H](C)[C@@H](C=O)[C@@]2(O)[C@](C)(C=O)CC(C)(C)[C@]12C</smiles>

265.1,8,9-Epibotrydial<smiles>C[C@H]1CC=C2C(=C1C=O)[C@](C)(C=O)CC2(C)C</smiles>

266. Botrydienal<smiles>CC(=O)OC1C[C@@H](C)C(C=O)=C2[C@@H](C=O)CC(C)(C)CC21C</smiles>

267. Botryendial<smiles>C[C@H]1C(=O)C=CC2=CC(=O)C(O)=CC21C</smiles>

268. Botryosphaeridione

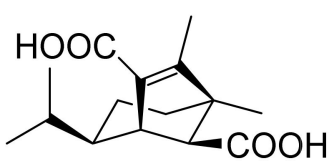

269. Cochliobolin A

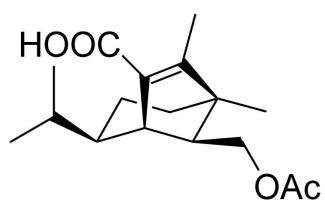

OAc

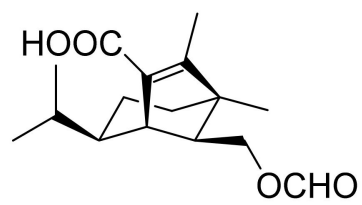

271. Cochliobolin $C$<smiles>COCC1=C(C)C2(C)CC1C1C(C(C)C)OCC12</smiles>

272. Cochliobolin D

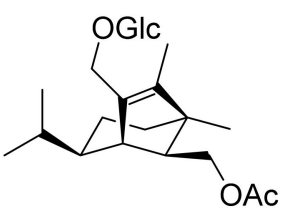

273. Cochliobolin E

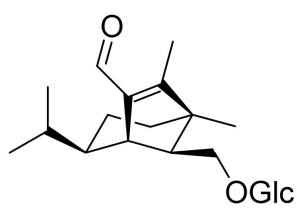

274. Cochilobolin F

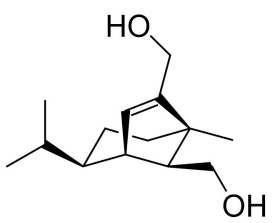

275. Drechslerine A 276. Drechslerine B

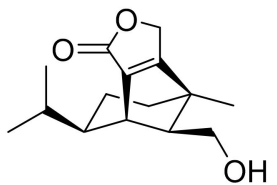<smiles>C[C@H]1C2=C(C(=O)C(O)[C@@H]1O)[C@@H]1CC(C)(C)[C@H]1C2O</smiles>

277. Fascicularone $A$

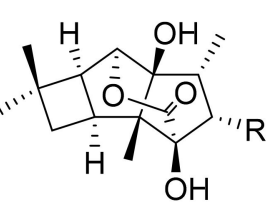

278. Fascicularone $B, R=H$

285. Fascicularone $\mathrm{I}, \mathrm{R}=\mathrm{OH}$

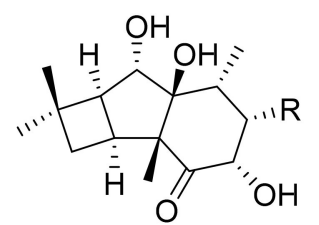

279. Fascicularone $\mathrm{C}, \mathrm{R}=\mathrm{H}$ 282. Fascicularone $\mathrm{F}, \mathrm{R}=\mathrm{OH}$

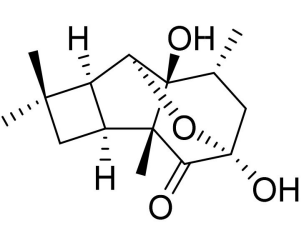

281. Fascicularone $E$

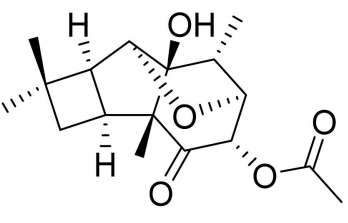

283. Fascicularone $G$

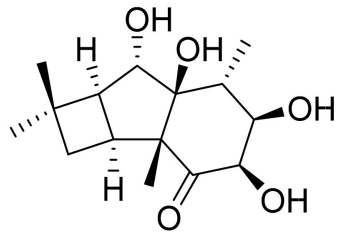

284. Fascicularone $\mathrm{H}$

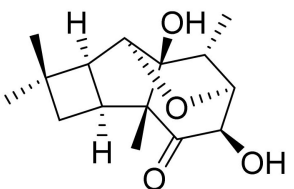

280. Fascicularone D

Figure 23. Cont. 
<smiles>CC1=C2C[C@]3(C)C(=C(O)C(=O)C[C@@H]3C)C=C2OC1=O</smiles>

288. 1-Hydroxy-2-oxoereophil-1(10), 7(11),8(9)-trien-12(8)-olide<smiles>CC(C)=C1C[C@]2(C)C(=CC1=O)[C@H](O)CC[C@H]2C</smiles>

289. $1 \alpha$-Hydroxyhydroisofukinon

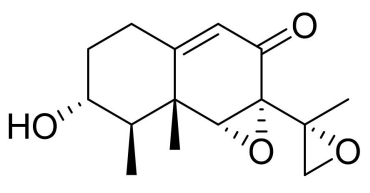

290. Gigantenone<smiles>CC(O)C1C2C(C(=O)O)C(C)C3(C)C(C)C1C23C</smiles>

291. Helminthosporal acid

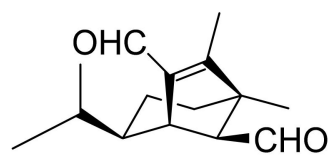

292. Helminthosporal

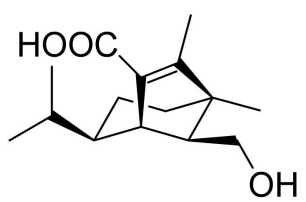

293. Helminthosporic acid

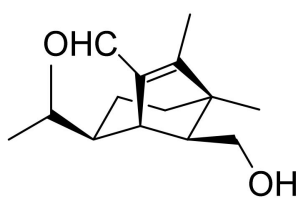

294. Helminthosporol

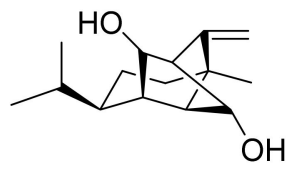

295. Prehelminthosporol 296. Dihydroprehelminthosporol 297. Prehelminthosporolactone 298. Isosativenediol<smiles>C=C(CO)[C@@H]1CC[C@@]2(O)[C@@H](O)CC[C@H](O)[C@]2(C)C1</smiles>

299. Lairdinol A

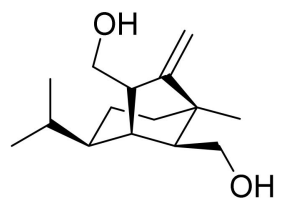

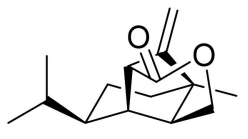<smiles>CC1[C@H](O)CCC2=CC(=O)[C@H](C3(C)CO3)CC21C</smiles>

303. 11,12-Epoxypetasol<smiles>C=C(C)[C@H]1CC2(C)C(=CC1=O)CCCC2C</smiles>

300. Petasol<smiles>C=C(C)C1=CC2(C)C(=CC1=O)CC[C@@H](O)C2C</smiles>

301. 6-Dehydropetasol<smiles>CC1[C@H](O)CCC2=CC(=O)C(C(C)(O)CO)=CC21C</smiles>

302. 6-Dehydro-11,12-dihydroxypetasol<smiles>C=C(C)[C@]1(O)CC(=O)C=C2CC[C@@H](O)[C@H](C)[C@@]21C</smiles>

304. 7-Hydroxypetasol<smiles>C=C(CO)[C@H]1C[C@]2(C)C(=CC1=O)CC[C@@H](O)C2C</smiles>

305. 13-Hydroxypetasol

306. Phaseolinone<smiles>C=C(CO)C1C(=O)C=C2CC[C@@H](O)C(C)C2(C)C1=O</smiles>

310. Phomenone<smiles>COC(OC)C1(C)OC12CC(C)(C)C1(C)C(=CC2=O)C2=C(O2)[C@H](OC(C)=O)C1C</smiles>

312. PR-toxin dimethyl acetal<smiles>[R]C1=C(C)C(C)(C)C2(C)CC([R7])C(=O)C=C2C(=O)C1</smiles>

316. Rhzoperemophilane $\mathrm{E}$, $\mathrm{R}_{1}=\mathrm{OH}, \mathrm{R}_{2}=2 \mathrm{H}$

313. Pyrenophoric acid, $\mathrm{R}_{1}=\mathrm{H}, \mathrm{R}_{2}=\beta-\mathrm{CH}_{3}, \mathrm{R}_{3}=\mathrm{OH}$ 314. Pyrenophoric acid $A, R_{1}=O H, R_{2}=\beta-C_{3}, R_{3}=H$ 315. Pyrenophoric acid $B, R_{1}=H, R_{2}=\alpha-C_{3}, R_{3}=O H$
317. Rhizoperemophilane $F$, $\mathrm{R}_{1}=\mathrm{H}, \mathrm{R}_{2}=\mathrm{O}$

Figure 23. Cont. 
<smiles>CC1=C(O)C(=O)C=C2C(=O)c3occ(C)c3CC21C</smiles>

318. Rhzoperemophilane $L$<smiles>C=C(C)[C@H]1[C@@H](O)C[C@]2(C)[C@@H]1CC[C@](C)(O)[C@@H]2C</smiles>

319. Seiricardine A

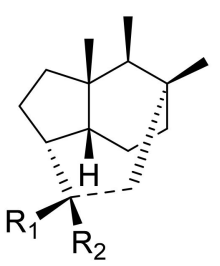

320. Seiricardine $B, R_{1}=\mathrm{CH}_{3}, \mathrm{R}_{2}=\mathrm{OH}$ 321. Seiricardine $C, \mathrm{R}_{1}=\mathrm{OH}, \mathrm{R}_{2}=\mathrm{CH}_{3}$

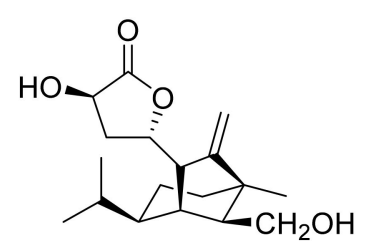

322. Sorokinianin<smiles>C=C(C)C1C(=O)C=C2CC[C@@H](O)C(C)C2(C)C1O</smiles>

323. Sporogen AO-1<smiles>C=C(C)C1=C(C)[C@H](O)C=C2CC[C@@H](O)C(C)C21C</smiles>

324. Dihydrosporogen AO-1<smiles>[R]c1occ2c1[C@@](C)(O)C1CC(C)(C)C=C1C2=O</smiles>

325. Sterostrein $\mathrm{H}, \mathrm{R}=\mathrm{CH}_{2} \mathrm{OH}$

326. Sterostrein $\mathrm{P}, \mathrm{R}=\mathrm{CHO}$

Figure 23. Structures of the phytotoxic sesquiterpenoids isolated from fungi.

Aspterric acid (259) was previously found from Aspergillus terreus to inhibit the pollen development of Arabidopsis thaliana. However, the mode of action was not clear [188]. This compound was later found to inhibit dihydroxy acid dehydratase (DHAD), which is an essential and highly conserved enzyme among plant species that catalyses $\beta$-dehydration reactions to yield $\alpha$-keto acid precursors to isoleucine, valine and leucine. DHAD along with other two enzymes: acetolactate synthase (ALS) and actohydroxy acid isomeroreductase (KARI) are three enzymes in the plant branched-chain amino acid (BCAA) biosynthetic pathway, which is essential for plant growth [189].

Bipolaroxin (260) and dihydrobipolaroxin (261) were isolated from Bipolaris cynodontis, the pathogen of Bermuda grass (Cynodon dactylon). Bipolaroxin (260) displayed selective phytotoxicity. Dihydrobipolaroxin (261) showed no phytotoxicity at $3.8 \mathrm{mM}$ against Bermuda grass, goosegrass, wheat and barley, which indicated that the $\mathrm{C} 12$ aldehyde was essential for activity [190]. Bipolaroxin (260) was also isolated from Bipolaris sorokini$a n a$, the causal agent of spot blotch of wheat. Wheat, barley, maize, and sorghum were sensitive to bipolaroxin (260) at $30 \mathrm{ng} / \mathrm{mL}$ while chickpea, tomato, cotton, and rice were insensitive [191].

Botrydial (262) and its epimer metabolites 1-epibotrydial (263), 8,9-epibotrydial (264) and 1,8,9-epibtrotrydial (265), as well as its unsaturated dialdehydes botrydienal (266) and botryendial (267) were isolated from the phytopathogen Botrytis cinerea. The unsaturated botrydienal (266) and botryendial (267) were more phytotoxic than epimers 1-epibotrydial (263), 8,9-epibotrydial (264) and 1,8,9-epibtrotrydial (265) by tabacco leaf assay [192]. Botrydial (262) from Botrytis cinerea was found to trigger phosphatidic acid production in tomato suspension cells, and phosphatidic acid was found to positively regulate the production of reactive oxygen species (ROS) [193].

Botryosphaeridione (268) was a trinor-eremophilane sesquiterpene isolated from Phoma sp. LN-16, an endophytic fungus associated with Melia azedarach. It inhibited the seed germination of lettuce (Lactuca sativa) with $\mathrm{IC}_{50}$ as $93.64 \mu \mathrm{g} / \mathrm{mL}$ [194].

A series of seco-sativene sesquiterpenoids including cochliobolins A-F (269-274), drechslerines A (275) and B (276), helminthosporal acid (291), helminthosporic acid (293), helminthosporol (294), and isosativenediol (298) were isolated from Cochiliobolus sativus, the endophytic fungus isolated from a desert plant Artemisia desertorum. Among them, cochliobolin F (274), drechslerine B (276), helminthosporal acid (291), and helminthosporic acid (293) displayed strong phytotoxic effects on corn leaves by producing visible lesions [23]. Both helminthosporal acid (291) and helminthosporol (294) were also isolated from Bipolaris sorokiniana. These two compounds inhibited seed germination of lettuce [195]. Helminthosporal (292) isolated from Helminthosporium sativum was toxic to barley root 
explants by seedling growth assay. It reacted directly with both the plasmalemma and the tonoplast membranes of the beet root cells [196].

Eleven sesquiterpenoids namely fascularones A-K (277-287) were isolated from the culture broth of Naematoloma fasciculare, a bitter poisonous mushroom distributed in northeast Japan. They all contained a cis-fused four-membered ring moiety, and promoted radicle elongation of lettuce seedlings [197-200].

In addition, 1-hydroxy-2-oxoeremophil-1(10),7(11),8(9)-trien-12(8)-olide (288) from Malbranchea aurantiaca showed significant inhibition of radicle growth of Amaranthus hypochondriacus seedlings with $\mathrm{IC}_{50}$ value of $6.57 \mu \mathrm{M}$. In addition, this compound inhibited activation of the calmodulin-dependent enzyme cAMP phosphodiesterase with $\mathrm{IC}_{50}$ of $10.2 \mu \mathrm{M}$ [111].

Prehelminthosporol (295) was isolated from Dreschlera sorokiana (syn. Helminthosprorium sativum, Bipolaris sorokiniana). This metabolite was a plant growth regulator that promoted shoot growth of rice seedlings but inhibited the coleoptile growth of wheat seedlings [201]. Prehelminthosporol (295) and dihydroprehelminthosporol (296) were isolated from the culture filtrates of Bipolaris species which was the pathogen of Johnson grass (Sorghum halepense), one of the worst weeds in tropical and subtropical areas of the world. Both metabolites were toxic towards sorghum (Sorghum bicolor) in leaf spot assay [202]. Prehelminthosporolactone (297) was latter isolated from the the culture filtrates of Bipolaris species to show toxic to the leaves of sorghum and sicklepod (Cassia obtusifolia) [203].

Nine phytotoxic eremophilane-type sesquiterpenoids namely gigantenone (290), petasol (300), 6-dehydropetasol (301), 6-dehydro-11,12-dihydroxypetasol (302), 11,12-epoxypetasol (303), 7-hyroxypetasol (304), 13-hydroxypetasol (305), phaseolinone (306), and phomenone (310) were isolated from some fungi such as Drechslera gigantean and Macrophomina phaseolina. They caused necrotic lesions on several grasses such as crabgrass (Digitaria spp.), quackgrass (Agropyron repens), and Bermuda grass (Cynodon dactylon) by leaf puncture assay [204]. Phaseolinone (306) also caused non-specific leaf necrosis on several plants, and inhibited seed germination of soybean [205].

Lairdionol A (299), phomalairdenol A (307), and phomalairdenones A (308) and D (309), were isolated from Leptosphaeria maculans. They showed selective phytotoxicity to brown mustard [206,207].

Two eremophilane-type sesquiterpenoids namely phomenone (310) and PR-toxin (311) were isolated from the cultures of Phoma destructiva. They inhibited radical elongation and shoot growth of tomato seedlings at $10^{-4} \mathrm{M}$. [208].

Pyrenophoric acid (313) and pyrenophoric acids B (314) and C (315) were isolated from seed pathogen Pyrenophora semeniperda of cheatgrass (Bromus tectorum). Three metabolites showed phytotoxic activity by reducing coleoptile elongation of cheatgrass seedlings $[209,210]$. Among three metabolites, pyrenophoric acid $B$ (314) was the most phytotoxic to use the abscisic acid (ABA) biosynthesis pathway at the level of alcohol dehydrogenase ABA2 to reduce seed germination of cheatgrass [211].

Moreover, $1 \alpha$-hydroxyhydroisofukinon (289), PR-toxin dimethyl acetal (312), and rhizoperemophilanes E (316), F (317), and L (318) were nitrogen-containing eremophilanetype sesquiterpenoids isolated from the endophytic fungus Rhizopycnis vagum. These metabolites inhibited radicle elongation of rice seedlings [212].

Seiricardines A (319), B (320), and C (321) were separately isolated from the culture filtrates of Seiridium cardinale, S. cupressi, and S. unicorne, that all were associated with canker disease of cypress (Cupressus sempervirens) in the Mediterranean area $[213,214]$. The solution of seiricardine A (319) at $0.3 \mathrm{mg} / \mathrm{mL}$ was absorbed by severed twigs of cypress to cause the leaf yellowing and browning. Subperidermal injection of the solution of seiricardine $A(319)$ at $0.1 \mathrm{mg} / \mathrm{mL}$ into young cypress trees caused necrotic lesions on the stem and a diffuse yellowing of adjacent twigs [213]. Seiricardines B (320) and C (321) were epimeric diastereomers. They showed similar phytotoxic activity to sericardine A (319) [214]. 
Sorokinianin (322) was isolated from the culture broth of Bipolaris sorokiniana, the pathogen of barley. This compound inhibited germination of the seeds of barley (Hordeum vulgare) [215].

Two eremophilane-type sesquiterpenes, namely sporogen $\mathrm{AO}-1$ (also called 13desoxyphomenone, 323) and dihydrosporogen AO-1 (324), were isolated from the coprophilous fungus Penicillium sp. G1-a14. Both sporogen AO-1 (323) and dihydrosporogen AO-1 (324) caused significant inhibition of radicle growth against Amaranthus hypochondriacus ( $\mathrm{IC}_{50}$ value of $0.17 \mathrm{mM}$ for both compounds) and Echinochloa crus-galli ( $\mathrm{IC}_{50}$ values of $0.17 \mathrm{mM}$ and $0.30 \mathrm{mM}$, respectively) [216]. Sporogen AO-1 (323) isolated from Hansfordia sp. 185-94 showed inhibition on seed germination of Lepidium sativum and Setaria italic [217].

Sterostreins H (325) and P (326) from Stereum complicatum showed inhibition on seed germination and growth of lettuce (Lactuca sativa), bentgrass (Agrostis stolonifera), and Lemna paucicostata [218].

\subsection{Diterpenoids}

Many diterpenoids from fungi exhibit phytotoxic activities. Structures of phytotoxic diterpenoids from fungi are shown in Figure 24. Aphidicolin (327) and its congeners 3-deoxyaphidicolin (328), aphidicolin-17-monoacetate (329), and aphidicolin-3,18orthoacetate (330) were isolated from Phoma betae, the pathogen of leaf spot disease on sugar beet. When these compounds were tested at $10^{-4} \mathrm{M}$, their inhibitory rates on root growth of lettuce seedlings were $74.3 \%, 50.9 \%, 58.1 \%$, and $54.5 \%$, respectively [219].

Chenopodolin (331) was an unrearranged ent-pimaradiene diterpene isolated from the pathogen Phoma chenopodiicola, which was proposed for the biological control of Chenopodium album, a common worldwide weed of arable crops such as sugar beet and maize. At concentration of $2 \mathrm{mg} / \mathrm{mL}$, the compound caused necrotic lesions on the leaves of Mercurialis annua, Cirsium arvense, and Setaria viride [220].

Fusicoccn A (332) and dideacetylfusicoccin A (333) were diterpene glycosides produced by the plant pathogenic fungus Fusicoccum amygdali (syn. Phomopsis amygdali) with a unque $\mathrm{O}$-prenylated glucose moiety. They stimulated seed germination of the parasitic weeds Orobanche spp. [221]. Further mechanism investigation showed that fusicoccn A (332) binded to a hydrophobic cavity in plant 14-3-3 proteins and stabilized the interaction with the C-terminal phosphorylated domain of plasma membrane $\mathrm{H}^{+}$-ATPase, thereby promoting stomatal opening and eventually leading to plant death [222].

Six diterpenoids named harziane (334), harzianelactones A (335) and B (336), and harzianones A (337), B (338) and C (339) were isolated from the soft coral-derived fungus Trichoderma harzianum XS-20090075. These harziane diterpenoids exhibited potent phytotoxicity against seedling growth of amaranth (Amaranthus retroflexus) and lettuce (Lactuca sativa) [223].

Some phytotoxic pimarane diterpenoids were isolated from the fungus Hypoxylon mammatum, the stem canker pathogen of aspen (Populus spp.). Hymatoxin A (340) was isolated from the culture broth of pathogenic fungus $H$. mammatum $[69,224]$. Hymatoxins B-E (341-344) [69], and hymatoxins K (345) and L (346) [225] were further isolated from the culture broth of Hypoxylon mammatum. Hamatoxins A-D (340-343) each had a sulfate group, and hamatoxins K (345) and L (346) were mannopyranosides, which made them hydrosoluble. These pimarane diterpenoids were all phytotoxic to the leaves of aspen.

Sphaeropsidin A (347) was a pimarane diterpene from Sphaeropsis sapinea f.sp. cupressi, the pathogen of a canker disease of cypress (Cupressus sempervirens). When this compound was absorbed by the servered twigs of Cupressus and cuttings of two herbaceous plants (tomato and oat), sphaeropsidin A (347) at $0.1 \mathrm{mg} / \mathrm{mL}$ produced leaf yellowing, browning and dieback [226]. The pathogen Sphaeropsis sapinea f.sp. cupressi also produced phytotoxins sphaeropsidins B (348) and C (349), and another pathogen Diplodia mutila produced phytotoxins sphaeropsidins A (347) and B (348) [227]. 


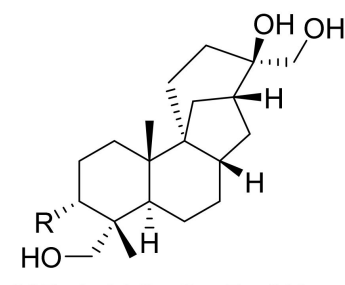

327. Aphidicolin, $\mathrm{R}=\mathrm{OH}$

328. 3-Deoxyaphidicolin, $\mathrm{R}=\mathrm{H}$

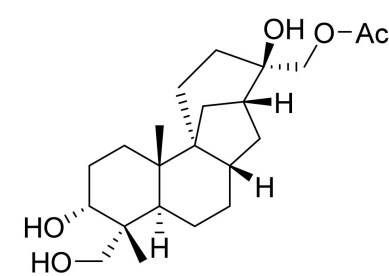

329.Aphidicolin-17-monoacetate

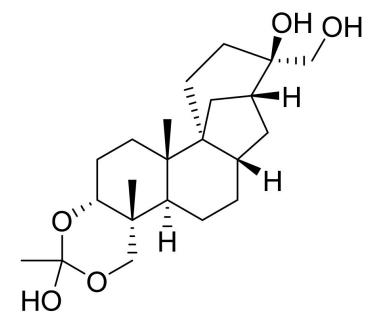

330. Aphidicolin-3,18-orthoacetate 331

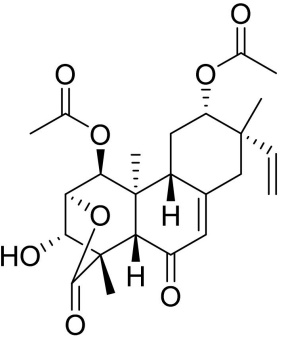

331. Chenopodolin

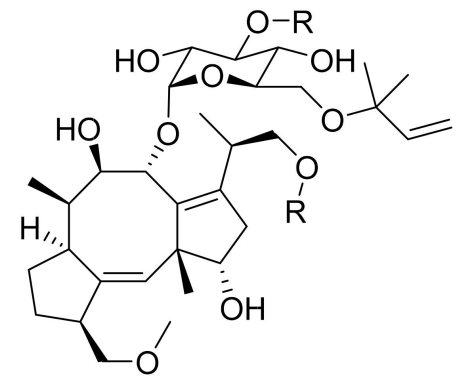

332. Fusicoccin $A, R=A c$

333. Dideacetylfusicoccin $A, R=H$

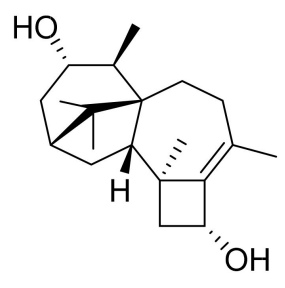

334. Harziane
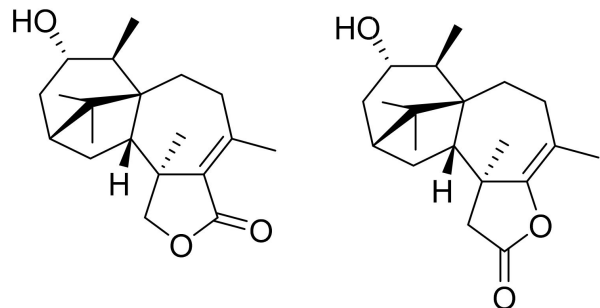

335. Harzinelactone A 336. Harzinelactone B

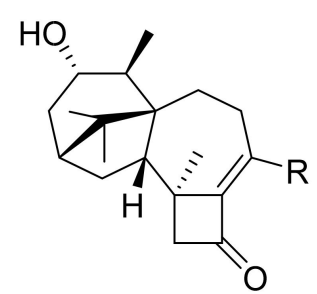

337. Harzianone $\mathrm{A}, \mathrm{R}=\mathrm{CH}_{3}$ 338. Harzianone $\mathrm{B}, \mathrm{R}=\mathrm{CH}_{2} \mathrm{OH}$
$\mathrm{HO}$,

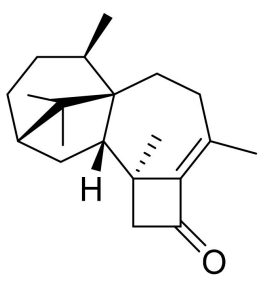

339. Harzianone C

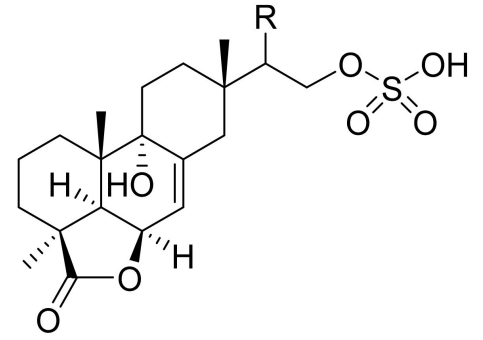

340. Hymatoxin $\mathrm{A}, \mathrm{R}=\mathrm{H}$ 341. Hymatoxin $\mathrm{B}, \mathrm{R}=\mathrm{OH}$

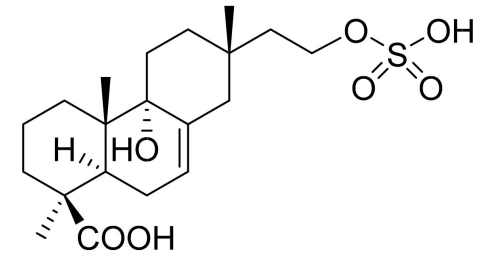

342. Hymatoxin $C$<smiles>CC1(CCOS(=O)(=O)O)C=CC2C(=C1)C=CC1C2CCC2C1(C)CCC[C@]2(C)C(=O)O</smiles>

343. Hymatoxin $D$

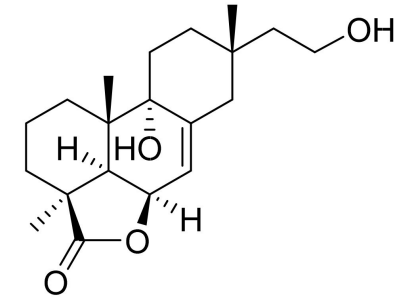

344. Hymatoxin $E$

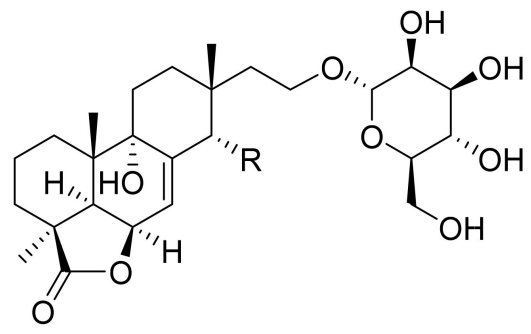

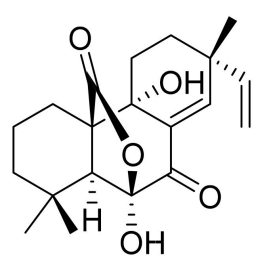

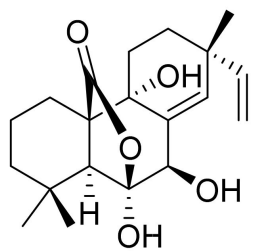

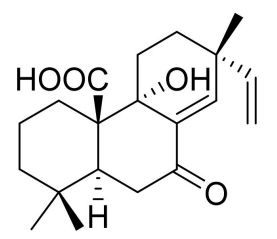

345. Hymatoxin $\mathrm{K}, \mathrm{R}=\mathrm{H}$ 346. Hymatoxin $\mathrm{L}, \mathrm{R}=\mathrm{OH}$

349. Sphaeropsidin C

Figure 24. Structures of the phytotoxic diterpenoids isolated from fungi. 


\subsection{Sesterterpenoids}

Fungal phytotoxic sesterterpenoids from fungi with their structures are shown in Figure 25. Representative phytotoxic sesterterpenoids are ophiobolin congeners which structures contain a tricyclic 5-8-5 carbotricyclic skeleton. Ophiobolins and their biological activities were well reviewed [228-230]. Bipolaris oryzae (syn. Helminthosporium oryzae, Cochliobolus oryzae, and Drechslera oryzae) is the pathogen of rice, maize and sorghum. It can produce phytotoxic ophiobolins.

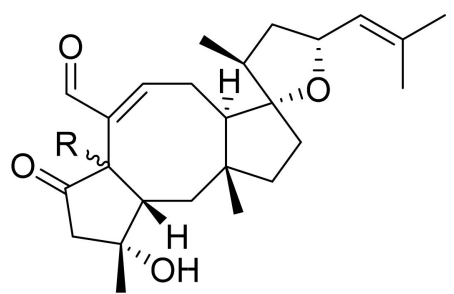

350. Ophiobolin $A, R=\beta H$

351. 6-epi-Ophiobolin $A, R=\alpha H$

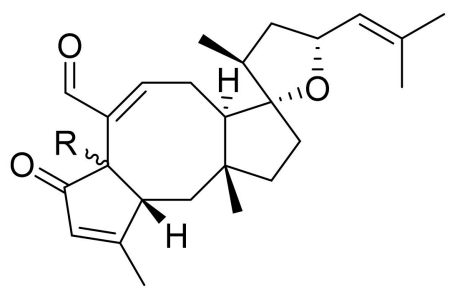

352. 3-Androophiobolin $A, R=\beta H$ 353. 3-Andro-6-epi-ophiobolin $A, R=\alpha H$

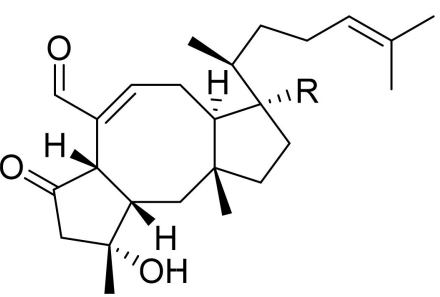

354. Ophiobolin $\mathrm{B}, \mathrm{R}=\mathrm{OH}$ 355. Ophiobolin $\mathrm{C}, \mathrm{R}=\mathrm{H}$<smiles>[R]CC(C)=C[C@@H]1C[C@H](C)[C@]2(CC[C@]3(C)C[C@@H]4C(C)=CC(=O)[C@H]4/C(CO)=C/C[C@@H]23)O1</smiles>

356. Ophiobolin I, $\mathrm{R}=\mathrm{H}$

357. 25-Hydroxyophiobolin I, R=OH

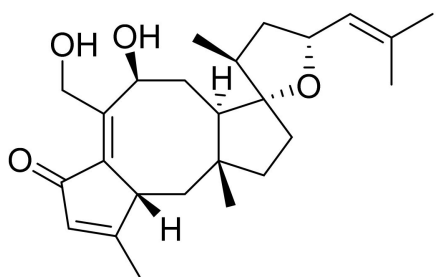

358. Ophiobolin J

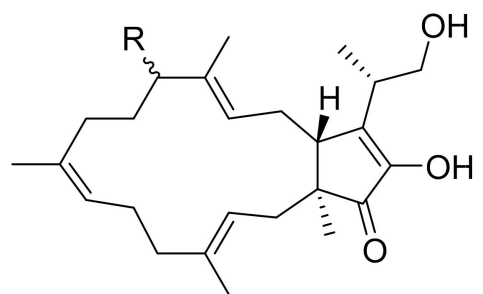

359. Terpestacin, $\mathrm{R}=\beta \mathrm{OH}$

360. 11-epi-Terpestacin, $\mathrm{R}=\alpha \mathrm{OH}$

Figure 25. Structures of the phytotoxic sesterterpenoids isolated from fungi.

Four sesterterpenoids namely ophiobolin A (350), 6-epi-ophiobolin A (351), 3anhydroophiobolin A (352), and 3-anhydro-6-epi-ophiobolin A (353) were produced by Bipolaris oryzae. They were toxic to the photosynthesis of rice plants by measurement of spinach leaf photosynthesis [231].

Ophiobolin A (350), 6-epi-ophiobolin A (351), 3-anhydro-6-epi-ophiobolin A (353), ophiobolin B (354), ophiobolin I (356), and ophiobolin J (358) were isolated from the liquid cultures of Drechslera gigantean, a cosmopolitan fungal pathogen of plants. They were toxic to large crabgrass (Digitaria sanguinalis) by leaf puncture detached assay. These ophiobolin sesterterpenoids were considered as potential natural herbicides [232].

Ophiobolin A (350), 6-epi-ophiobolin A (351), 3-anhydroophiobolin A (352), and 3anhydro-6-epi-ophiobolin A (353) were also isolated from plant pathogen Bipolaris sorghicola. When tested on several plants by using a leaf spot assay, ophiobolin A (350) and 6-epiophiobolin A (351) were more phytotoxic than their anhydro derivatives 3-anhydroophiobolin A (352) and 3-anhydro-6-epi-ophiobolin A (353) against sorghum (Sorghum bicolor), sicklepod (Cassia obtusifolia), and maize (Zea mays) [233].

The phytotoxic ophiobolin congeners from fungi were summarized as ophiobolin A (350), 6-epi-ophiobolin A (351), 3-anhydroophiobolin A (352), 3-anhydro-6-epi-ophiobolin A (353), ophiobolin B (354), ophiobolin C (355), ophiobolin I (356), 25-hydroxyophiobolin I (357), and ophiobolin J (358) [229]. Among them, ophiobolin A (350) was proven to be the most phytotoxic to almost all of the tested plants. The structures of 3-anhydroophiobolin A (352) and 3-anhydro-6-epi-ophiobolin A (353) lacked a hydroxyl group at C-3 on the basis of ophiobolin A (350) and 6-epi-ophiobolin A (351), respectively. The hydroxyl (C-3) of ophiobolin A (350) improved the inhibition against barley and cabbage, reduced the activity on tested plants, while the activity on the remaining tested plants was unchanged. Furthermore, the stereochemistry at C-6, and the aldehyde group at C-7 were also important 
for the phytotoxicity of the molecules [234,235]. Ophiobolins have been considered to have the herbicidal potential to control weeds $[229,230]$.

Ophiobolin C (355), ophiobolin I (356) and 25-hydroxyophiobolin I (357) were isolated the cultures of Drechslera maydis, the causal agent of Southern corn leaf blight. These compounds were toxic to corn, Johnson grass, and sorghum by leaf-wouding assay [234]. Ophiobolin J (358) was later isolated from D. maydis, and showed a similar phytotoxicity [236].

Two bicycle sesterterpenes named terpestacin (359) and 11-epi-terpestacin (also called siccanol, 360) were isolated from the cultures of Bipolaris sorokiniana NSDR-011. Both metabolites showed inhibition on the root growth of Italian ryerass seedlings [237]. Terpestacin (359) was also isolated from Neufusicoccum batangarum, the causal agent of the scabby canker of cactus pear (Opuntia ficus-indica). Terpestacin (359) showed phytotoxicity on either tomato with the leaf puncture assay or cactus pear with cladode puncture assay [74].

\subsection{Triterpenoids}

Phytotoxic triterpenoids are mainly isolated from the fungi of Basidiomycetes. Their structures are shown in Figure 26. Three lanostane triterpenoids namely aeruginosols A (361), B (362) and C (363) were isolated from the fruiting bodies of Stropharia aeruginosa. Among them, aeruginosol C (362) showed root growth inhibitory activity on lettuce seedlings [238].

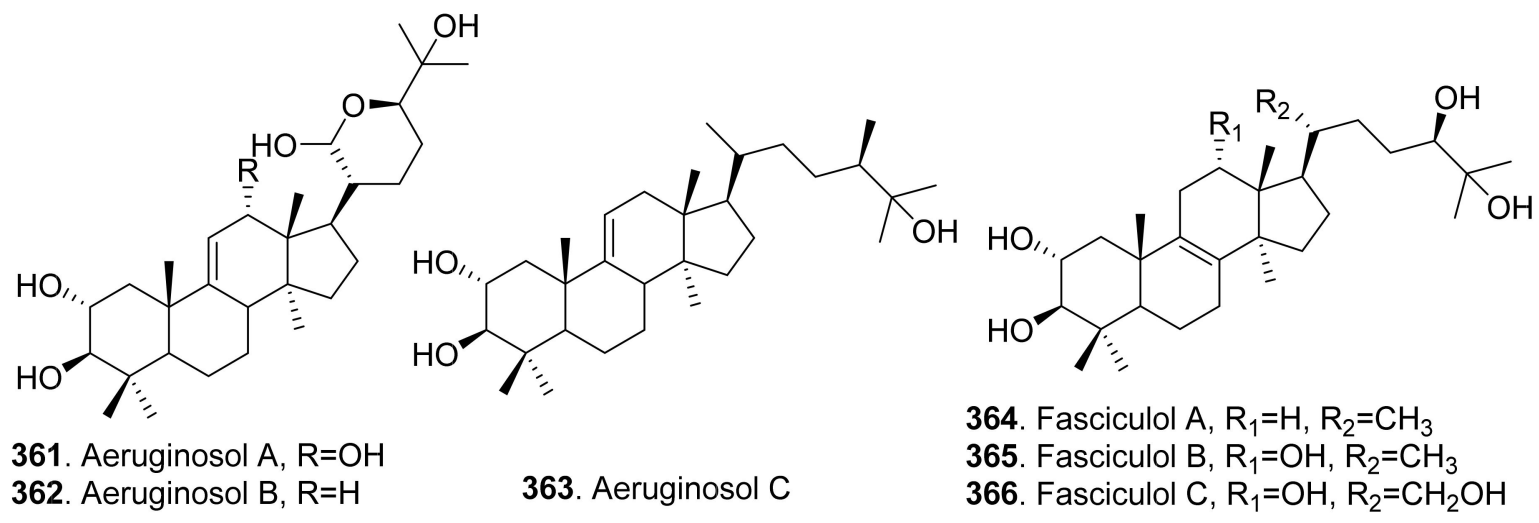

Figure 26. Structures of the phytotoxic triterpenoids isolated from fungi.

Fasciculols A (364), B (365) and C (366) were isolated from fruiting bodies of Neamatoloma fasciculare. They all inhibited root elongation of Chinese cabbage seedlings. The inhibitory activity of fasciculol A (364) was only one-fourth of those of fasciculols B (365) and C (366) [239-241].

\subsection{Meroterpenoids}

Meteroterpenoids are natural products that are partially derived from terpenoid biosynthetic pathways. Phytotoxic meteroterpenoids usually contain monoterpene, sesquiterpene, and diterpene biosynthetic pathways.

\subsubsection{Meroterpenoids Containing Monoterpene Biosynthetic Pathways}

The structues of fungal phytotoxic meroterpenoids contain monoterpene biosynthetic pathways are shown in Figure 27. Foeniculoxin (367), a geranylhydroquinone, was isolated from Phomopsis foeniculi which was the fungal pathogen (Phomopsis foeniculi) of fennel (Foeniculum vulgare subsp. vulgare) to cause the necrosis of stems, leaves and inflorescences leading to a marked decrease in fruit production [242]. 
<smiles>C=C(C#Cc1cc(O)ccc1O)CCC(O)C(C)(C)O</smiles>

367. Foeniculoxin<smiles>C=C(C)[C@H]1CC[C@]2(C)OC3=C(CC12)C(=O)[C@]1(O)COC3C1</smiles>

368. Guignardone A<smiles>CO[C@H]1C[C@@H](O)C(=O)C2=C1OC(C(C)(O)CCC=C(C)C)C2</smiles>

369. Phyllostictone A

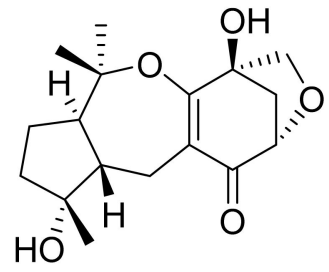

370. Phyllostictone B<smiles>C=C(C#CC1=C[C@H](O)[C@H](OC)[C@H](O)[C@@H]1O)CCC=C(C)C</smiles>

373. Phomentrioloxin<smiles>C=C(CO)[C@H]1CC[C@]2(C)OC3=C(C[C@H]12)C(=O)[C@H]1CO[C@H]3O1</smiles>

371. Phyllostictone C<smiles>C=C(C#CC1=C[C@@H](O)[C@H](OC)[C@H](O)C1=O)CCC=C(C)C</smiles>

374. Phomentrioloxin B<smiles>CO[C@H]1C[C@@H](O)C(=O)C2=C1O[C@@]1(C)CC[C@H](C(C)(C)O)[C@H]1C2</smiles>

372. Phyllostictone $\mathrm{E}$<smiles>C=C(C#CC1=C[C@H](O)[C@H](OC)C(=O)[C@H]1O)CCC=C(C)C</smiles>

375. Phomentrioloxin C

Figure 27. Structures of the phytotoxic meroterpenoids with monoterpene pathways isolated from fungi.

Guignardone A (368) was isolated from the culture filtrates of Macrophomina phaseolina which was the charcoal rot pathogen of many crops. It was toxic to the non-host plant tomato leaf puncture assay. However, it did not show phytotoxic activity to the host plant soybean [243].

Phyllostictones A-C (369-371), and E (372) were isolated from the endophytic fungus Phyllosticata capitalensis derived from the plant Cephalotaxus fortune. These three compounds inhibited shoot and root growth of Lactuca sativa and Lolium perenne seedlings [21].

Phomentrioloxin (373), a phytotoxic geranylcyclohexenetriol, was isolated from the liquid culture of Phomopsis sp. (teleomorph: Diaporthe gulyae) which was isolated from symptomatic saffron thistle (Carthamus lanatus). Phomentrioloxin (373) causes the appearance of necrotic spots when applied to the leaves of both host and non-host plants. It also caused growth and chlorophyll content reduction of the fronds of Lemna minor and inhibition of tomato rootlet elongation [244]. The structure-activity relationship study showed that the hydroxy groups at C-2 and C-4 appeared to be important features for the phytotoxicity, as well as an unchanged cyclohexentriol ring and the unsaturations of the geranyl side chain [245].

Phomentrioloxins B (374) and C (375) were isolated from Diaporthe gulyae, the pathogen of sunflower (Helianthus annuus) by causing stem canker. Phomentrioloxin B (374) showed small but clear necrotic spots on a number of plant specices when assayed at $5 \mathrm{mM}$ on punctured leaf disks of weedy and crop plants [125].

\subsubsection{Meroterpenoids Containing Sesquiterpene Biosynthetic Pathways}

The structures of fungal phytotoxic meroterpenoids contain sesquiterpene biosynthetic pathways are shown in Figure 28. 4ß-Acetoxytetrahydrobotryslactone (376) was isolated from the culture broth of Botrytis cinerea. This lactone compound showed a phytotoxic effect on Phaseolus vulgaris when tested up to $250 \mu \mathrm{g} / \mathrm{mL}$ by leaf disk assay. It was specu- 
lated that the biosynthetic origin of this compound belonged to sesquiterpene-polyketide pathway [246].<smiles>CC(=O)O[C@H]1C[C@@H](C)C([C@H]2CC(O)C(=O)O2)=C2[C@H](CO)[C@@H](C)C[C@@H](C)[C@H]21</smiles>

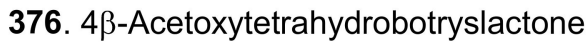

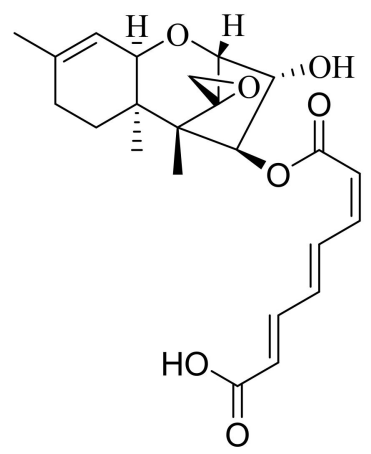

377. Harzianum A

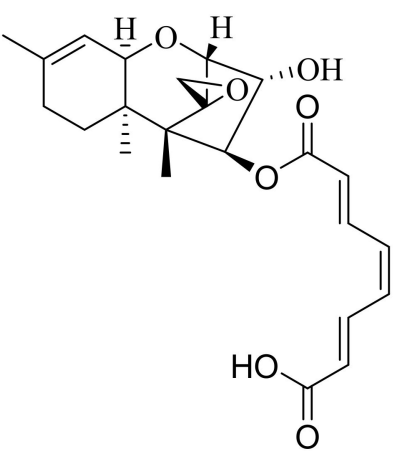

378. Harzianum B

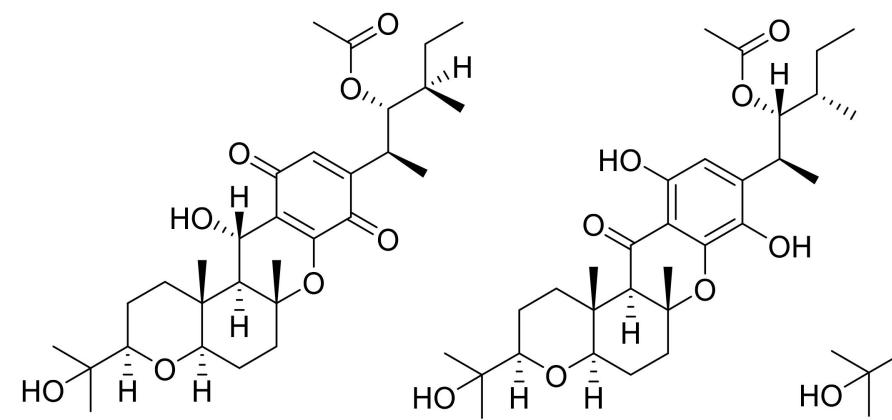<smiles>CCC(=O)C1=CCC2(CC)CCC3OC(C)CCC3(C)C2C1</smiles><smiles>C=C(C(=O)CC(=C)C(C)C(C)(C)O)C(C)C(=O)[C@H](C)CC</smiles>

379. Cochlioquinone $A$

380. Isocochlioquinone $A$

381. Cochlioquinone $B$

384. Stemphone<smiles>C/C(=C/CCC(O)C(C)(C)O)[C@H]1CC[C@]2(C)OC3=C(CC12)C(=O)[C@]1(O)COC3O1</smiles>

382. Phyllostictone D<smiles>CC(=O)O[C@H]1C(=O)C=C2C=C3NC(=O)C(C)=C3C[C@@]2(C)[C@H]1C</smiles>

383. Rhizoperemophilane M

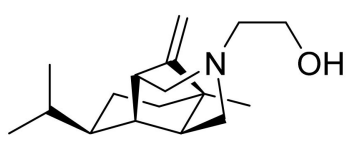

385. Victoxinine

Figure 28. Structures of the phytotoxic meroterpenoids with sesquiterpene pathways isolated from fungi.

Four meroterpenoid quinones cochlioquinons A (377) and B (378), isocolioquinone A (379), and stemphone (384) were isolated from the cultures of Bipolaris bicolor, the pathogen of gramineous plants such as rice and millet. They inhibited the root growth of the seedlings of finger millet and rice [247]. Their absolute configurations were further elucidated by spectroscopic data interpretation, single-crystal X-ray diffraction analysis, chemical transformations, and biosynthetic considerations [248]. They belonged to polyketidesesquiterpenoid hybrid compounds biosynthesized through type I polyketide gene cluster by genome sequence analysis of Bipolaris sorokiniana [249].

Harzianums A (380) and B (381) were isolated from the biofertilizer fungus Trichoderma brevicompactum. They consisted of the core sesquiterpenoid structure $(12,13-$ epoxytrichothec-9-ene) connected with a linear polyketide-derived substituent (octa-2,4,6trienedioyl) via an ester bond at C-4. Both harzianums A (380) and B (381) reduced both shoot and root lengths at low concentrations and inhibited the seed germination of Brassica chinensis, Oryza sativa, Echinochloa crusgalli at $2 \mu \mathrm{g} / \mathrm{mL}$ [250].

Phyllostictone D (382) was isolated from the endophytic fungus Phyllosticata capitalensis derived from Cephalotaxus fortune. This compound inhibited shoot and root growth of Lactuca sativa and Lolium perenne seedlings [21]. 
Rhizoperemophilane M (383) was a nitrogen-containing eremophilane-type sesquiterpenoids isolated from the endophytic fungus Rhizopycnis vagum. This metabolite inhibited radicle elongation of rice seedlings [212].

Victoxinine (385) was a nitrogen-containing sesquiterpenoid isolated from Bipolaris sp., the pathogen of Johnson grass (Sorghum halepense). It was toxic to the leaves of sorghum (Sorghum bicolor), sicklepod (Cassia obtusifolia), maize (Zea mays), morning glory (Ipomea purpurea), and bentgrass (Agrostis alba) [203].

\subsubsection{Meroterpenoids Containing Diterpene Biosynthetic Pathways}

The structures of fungal phytotoxic meroterpenoids contain diterpene biosynthetic pathways are shown in Figure 29. Three meroterpenoids namely colletotrichin (also called colletotrichin A, 386), colletotrichin B (387) and colletotrichin C (388) were isolated from the cultures of Colletotrichum nicotianae. Their structures all contained a norditerpene and a polysubstituted $\gamma$-pyrone. When applied to tobacco leaves, these compounds induced symptoms similar to those of the tobacco anthracnose caused by C. nicotianae [121]. They were also toxic to lettuce and rice seedlings [251].<smiles>[R7]O[C@H]1CC[C@]2(C)[C@H](Cc3c(OC)oc(C)c(C(=O)OC)c3=O)C(=C)CC[C@H]2[C@]1(C)CCC(C)(C)O[R2]</smiles>

386. Colletotrichin, $\mathrm{R}_{1}=\mathrm{R}_{2}=\mathrm{H}$

387. Colletotrichin $\mathrm{B}, \mathrm{R}_{1}=\mathrm{CHO}, \mathrm{R}_{2}=\mathrm{H}$

388. Colletotrichin $\mathrm{C}, \mathrm{R}_{1}=\mathrm{H}, \mathrm{R}_{2}=\mathrm{CHO}$

Figure 29. Structures of the phytotoxic meroterpenoids containing diterpene pathways isolated from fungi.

\section{Nitrogen-Containing Metabolites}

Phytotoxic nitrogen-containing metabolites include cyclic peptides, noncyclic oligopeptides, cytochalasins, lactams, indoles, pyridines, amines and noncyclic amides, and others.

\subsection{Cyclic Peptides}

Cyclic peptides are cyclic compounds formed mainly by the amide bonds between either proteinogenic or non-proteinogenic amino acids. Phytotoxic cyclic peptides from fungi mainly include ester bond-containing cyclic peptides (or called cyclic depsipeptides) and ester bond-uncontaining cyclic peptides.

\subsubsection{Cyclic Depsipeptides}

Cyclic depsipeptides (CDPs) are cyclopeptides in which amide groups are replaced by corresponding lactone bonds due to the presence of a hydroxylated carboxylic acid in the peptide structure [252]. The structures of phytotoxic cyclic depsipeptides from fungi are shown in Figure 30. 


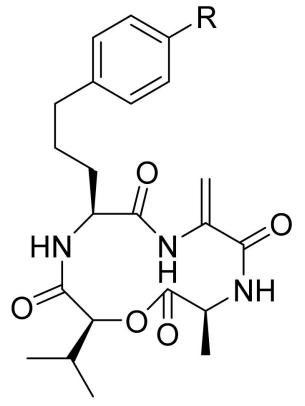

389. AM-toxin I, $\mathrm{R}=\mathrm{OCH}_{3}$ 390. AM-toxin II, R=H 391. AM-toxin III, $\mathrm{R}=\mathrm{OH}$<smiles>C=C(C)C[C@H](OC(=O)CCNC(=O)[C@H](C)N(C)C(=O)[C@@H](C(C)C)N(C)C(=O)[C@@H](NC(=O)[C@@H]1CCCN1C)C(C)CC)C(C)C</smiles>

393. Destruxin $B, \mathrm{R}_{1}=\mathrm{CH}_{3}, \mathrm{R}_{2}=\mathrm{H}, \mathrm{R}_{3}=\mathrm{CH}_{3}$

394. Hydroxydestruxin $\mathrm{B}, \mathrm{R}_{1}=\mathrm{CH}_{3}, \mathrm{R}_{2}=\mathrm{OH}, \mathrm{R}_{3}=\mathrm{CH}_{3}$

395. Desmethyldestruxin $B, \mathrm{R}_{1}=\mathrm{CH}_{3}, \mathrm{R}_{2}=\mathrm{H}, \mathrm{R}_{3}=\mathrm{H}$

396. Homodestruxin $B, \mathrm{R}_{1}=\mathrm{CH}_{2} \mathrm{CH}_{3}, \mathrm{R}_{2}=\mathrm{H}, \mathrm{R}_{3}=\mathrm{CH}_{3}$

397. Hydroxyhomodestruxin $\mathrm{B}, \mathrm{R}_{1}=\mathrm{CH}_{2} \mathrm{CH}_{3}, \mathrm{R}_{2}=\mathrm{OH}, \mathrm{R}_{3}=\mathrm{CH}_{3}$

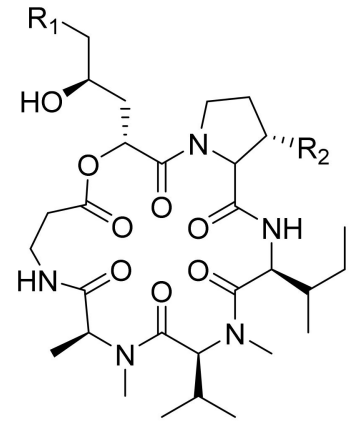

398. Dextruxin $\mathrm{E}$ chlorohydrin, $\mathrm{R}_{1}=\mathrm{Cl}, \mathrm{R}_{2}=\mathrm{H}$ 399. [ $\beta$-MePro]Dextruxin $E$ chlorohydrin, $\mathrm{R}_{1}=\mathrm{Cl}, \mathrm{R}_{2}=\mathrm{CH}_{3}$

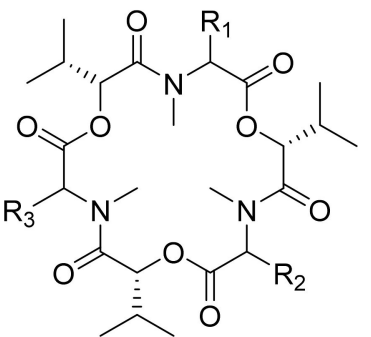

400. Enniatin $A, \mathrm{R}_{1}=\mathrm{R}_{2}=\mathrm{R}_{3}=\mathrm{CH}\left(\mathrm{CH}_{3}\right) \mathrm{CH}_{2} \mathrm{CH}_{3}$

401. Enniatin $A_{1}, R_{1}=R_{2}=\mathrm{CH}\left(\mathrm{CH}_{3}\right) \mathrm{CH}_{2} \mathrm{CH}_{3}$. $\mathrm{R}_{3}=\mathrm{CH}\left(\mathrm{CH}_{3}\right)_{2}$

402. Enniatin $B, R_{1}=R_{2}=R_{3}=C H\left(C_{3}\right)_{2}$

403. Enniatin $\mathrm{B}_{1}, \mathrm{R}_{1}=\mathrm{CH}\left(\mathrm{CH}_{3}\right) \mathrm{CH}_{2} \mathrm{CH}_{3}$ $\mathrm{R}_{2}=\mathrm{R}_{3}=\mathrm{CH}\left(\mathrm{CH}_{3}\right)_{2}$<smiles>C/C=C(/NC(=O)C(NC(=O)[C@H](CC(C)C)NC(=O)C(CC(C)C)OC(=O)[C@H](Cc1ccccc1)OC(=O)C(C)C)C(C)C)C(=O)NC(C)C</smiles>

406. Phomalide

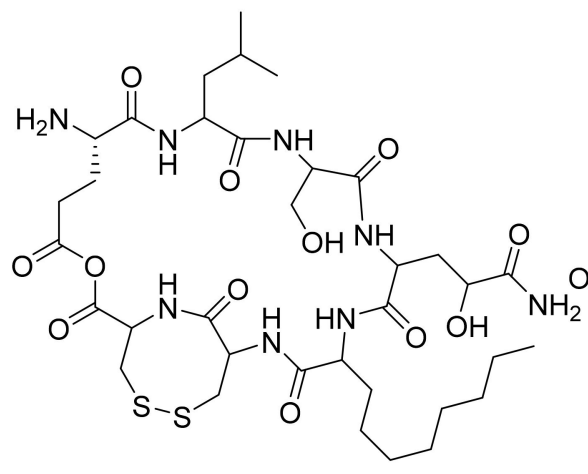

404. Gramillin A

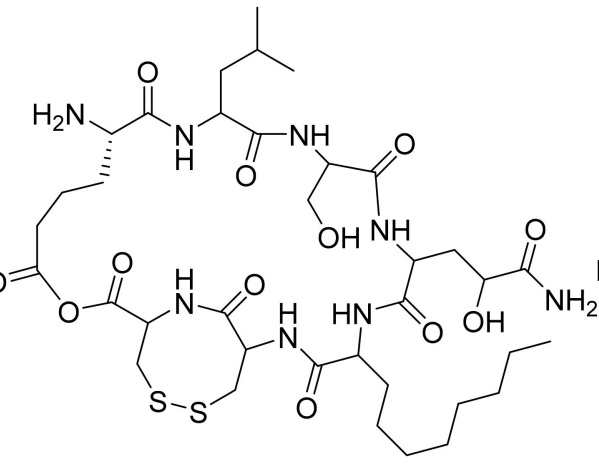

405. Gramillin B<smiles>C=CC[C@H](OC(=O)CNC(=O)C(C)N(C)C(=O)C(C(C)C)N(C)C(=O)C(NC(=O)C1C(C)CCN1C(=O)C(CC)CC)C(C)C)C(=O)NC</smiles>

407. Roseotoxin B

Figure 30. Structures of the phytotoxic cyclic depsipeptides isolated from fungi.

AM-toxins I (389), II (390) and III (391) belong to cyclic tetradepsipeptides. They were host-specific phytotoxins isolated from Alternaria mali, the pathogen of apple blotch disease $[253,254]$. It was found that AM-toxin I (389) inhibited photosynthetic $\mathrm{O}_{2}$ evolution in a host-specific manner [255].

Destruxin congeners are cyclic hexadepsipeptides belonging to host-specific phytotoxins. Destruxin A (392) was isolated from the culture broth of Alternaria linicola, the seed-borne pathogen of linseed (Linum usitatissimum). The infected seeds caused poor germination and damping-off of the seedlings. Alternaria linicola also caused leaf spotting on seedling and adult plants, and a form of head blight in the seed capsules which resulted in a loss of yield and reduction in oil quality [256]. Three cyclic hexadepsipeptides, namely destruxin B (393), desmethyldestruxin B (395) and homodestruxin (396), were isolated from 
the culture filtrates of Alternaria brassicae, the pathogen responsible for the balck spot of canola. They were assayed on the leaves of host and non-host plants. Dextruxin B (393) induced symptoms ranging from severe chlorosis and necrosis to almost no visible chlorosis. Dextruxin B (393) was proved as the host specific phytotoxin [257]. Both destruxin B (393) and homodestruxin B (396) could be transformed to hydroxydestruxin B (394) and hydroxyhomodestruxin B (397), respectively by host plants. The hydroxylated products (394 and 397) were less phytotoxic than their corresponding destruxins. It was considered as the detoxification strategy of canola against Alternaria fungi [258].

Two destruxin E derivatives, namely destruxin E chlorohydrin (398) and [ $\beta-\mathrm{Me}-$ Pro]destruxin E chlorohydrin (399) from Beauveria feline were screened to have phytotoxic activity against the radicle growth of Amaranthus retroflexus seedlings. The structure-activity study showed that chlorine atom played an important role for their phytotoxic activity [28].

Phytotoxic enniatin derivatives included enniatins A (400), A1 (401), B (402), and B1 (403). They belong to the class of cyclodepsipeptides found in various Fusarium species, and consist of alternating residues of D-2-hydroxyisovaleric acid and a branched chain $\mathrm{N}$-methyl L-amino acid, linked by peptide and ester bonds. Enniatins are host non-specific toxins which caused wilt and necrosis during infection of the host, probably related to their ionophoric properties [259]. Enniatins from Fusarium tricinctum reduced the growth of germination of wheat seeds [260]. Enniatins might act synergistically as a phytotoxin complex, which caused wilt and necrosis of plant tissue [261]. Enniatin B (402) and acetamido-butenolide (515) isolated from Fusarium avenaceum, the pathogen of spotted knapweed (Centaurea maculosa), also acted synergistically to cause necrotic lesions on the leaves of different plant species [262].

Two bicyclic lipopeptides, gramillins A (404) and B (405), were isolated from Fusarium graminearum. They were produced in planta in maize silks by promoting fungal virulence on maize, but had no discernible effect on wheat head infection. Leaf infiltration of the gramillins induced cell death in maize, but not in wheat. This indicated that gramillins were host-specific phytotoxins which were deployed as the virulence agents by F. graminearum in maize [263].

Phomalide (406) was a host-selective phytotoxin isolated from the virulent isolates of Leptoshphaeria maclans. It was a cyclic pentadepsipetide with three $\alpha$-mino acids and two $\alpha$-hydroxy acids. Phomalide (406) caused disease symptoms (necrotic, chlorotic, and reddish lesions) on canola, but not on either brown or white mustard [264].

Roseotoxin B (407) was isolated from Trichothecium roseum, the pathogen of apple pathogen. This metabolite was able to penetrate apple peel and produced chlorotic lesions by using kinetic fluorescence imaging method. It was the direct evidence of phytopathogenic activity of reseotoxin B (407) of Trichothecium roseum on apple [265].

\subsubsection{Cyclic Peptides without Ester Bond}

Cyclic peptides without ester bond are cyclic metabolites formed only by proteinogenic or non-protenogenic amino acids joined together by amide bonds (or peptide bonds). They mainly include cyclic di-, tri-, tetra-, penta-, hexa-, hepta-, octa-, nona-, and decapeptides [266,267]. Among them, cyclodipeptides are the most important group. Cyclodipeptides are also called 2,5-diketopiperazines or dioxopiperazines [266]. The structures of phytotoxic cyclodipeptides from fungi are shown in Figure 31. 


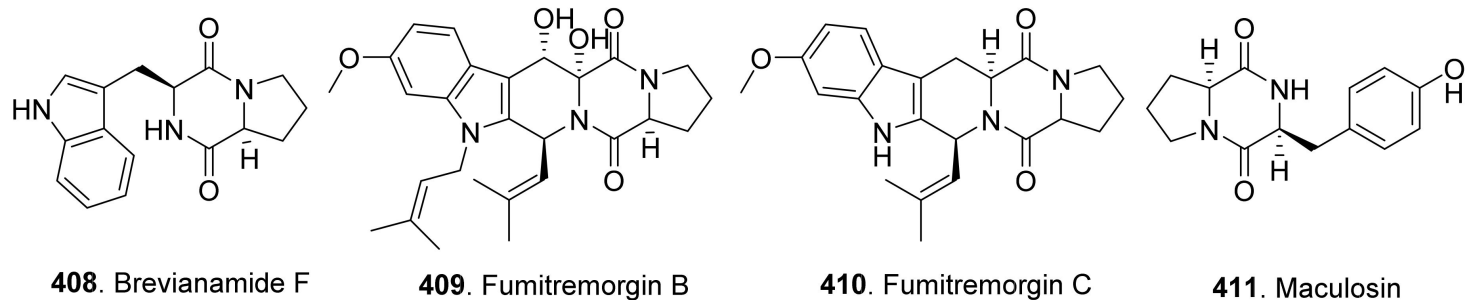

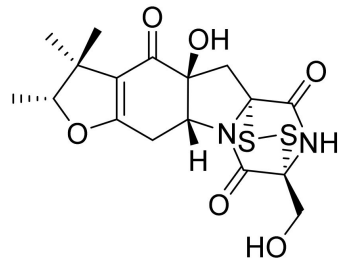

412. Phomalirazine<smiles>[R1]C1NC(=O)[C@]([R2])(C(C)C)NC1=O</smiles>

413. Polanzarine $A, R_{1}=H, R_{2}=H R=A C$ 414. Polanzarine $B, \mathrm{R}_{1}=\mathrm{SCH}_{3}, \mathrm{R}=\mathrm{SCH}_{3}$ 415. Polanzarine $\mathrm{C}, \mathrm{R}_{1}=\mathrm{OH}, \mathrm{R}_{2}=\mathrm{OH}$ 416. Polanzarine $D, \mathrm{R}_{1}=\mathrm{SCH}_{3}, \mathrm{R}_{2}=\mathrm{OH}$ 417. Polanzarine $\mathrm{E}, \mathrm{R}_{1}=\mathrm{OH}, \mathrm{R}_{2}=\mathrm{OH}$

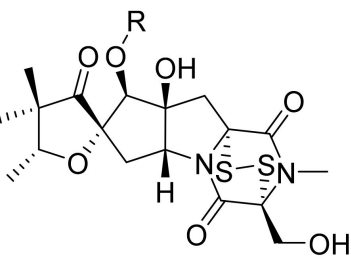

420. Sirodesmin $G, R=A c$

421. Deacetylsirodesmin $P L, R=H$

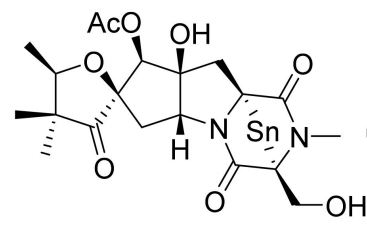

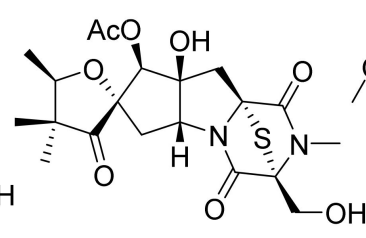<smiles>C/C=C\[C@@H]1c2c([nH]c3cc(OC)ccc23)C(OC)[C@@]2(O)C(=O)N3CCC[C@H]3C(=O)N12</smiles><smiles>COc1ccc2c(c1)NC(=O)[C@]21C=C2C(=O)N3CCCC3C(=O)N2C1=O</smiles>

418. Sirodesmin $B, n=4$

422. Sirodesmin $\mathrm{H}$

423. Cyclotryprostatin B 424. 6-Methoxyspirotryprostatin B<smiles>COc1ccc2c(CC3NC(=O)[C@@H]4CCCN4C3=O)c(C(=O)C=C(C)C)[nH]c2c1</smiles>

425. 18-Oxotryprostatin A

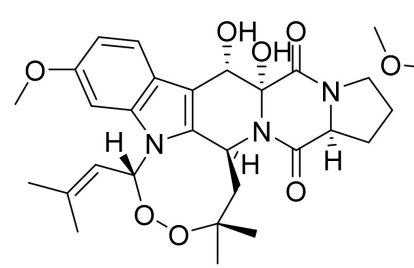

426. Verruculogen<smiles>COCN1C(=O)[C@@]2(O)[C@@H](O)c3c([nH]c4cc(C)ccc34)[C@H](CC(C)(C)O)N2C(=O)[C@H]2CCCN21</smiles>

428. $12 \beta$-Hydroxy-13 $\alpha$ methoxyverruculogen

Figure 31. Structures of the phytotoxic cyclodipeptides isolated from fungi.

Brevianamide $F$ (also called cyclo( ${ }_{L}-\operatorname{Trp}_{-}-\mathrm{P}$-Pro), 408), fumitremorgin B (409), fumitremorgin C (410), cyclotryprostatin B (423), 6-methoxyspirotryprostatin B (424), 18-oxotryprostatin A (425), verruculogen (426), verruculogen TR-2 (also called TR-2, 427), and $12 \beta$-hydroxy$13 \alpha$-methoxyverruculogen TR-2 (428) were tryptophan-proline cyclodipeptides isolated the endophytic fungus Aspergillus fumigatus derived from the plant Melia azedarach. They inhibited shoot and root elongation of the seedlings of turnip (Raphanus sativus) and amaranth (Amaranthus mangostanus) [268].

Maculosin (411) was a host-specific phytotoxin isolated from Alternaria alternata, the pathogen of black leaf blight disease of spotted knapweed (Centaurea maculosa) [93,269].

Phomalirazine (412) was isolated from Leptosphaeria maculans, the pathogen of canola. This compound was to toxic to canola and brown mustard by leaf puncture assay [270].

Polanrazines A (413), B (414), C (415), D (416) and E (417) were isolated from Polish isolates of Leptosphaeria maculans, and showed moderate toxicity on the leaves of brown mustard [271].

Phytotoxic sirodesmin congeners such as sirodesmins B (418), C (419), G (also called sirodesmin PL, 420), and H (422), and deacetylsirodesmin PL (421) were isolated from cultures of Leptosphaeria maculans, the blackleg canker pathogen of oilseed rape (Brassica napus). The phytotoxicity was partly due to the sulfur bridge $[270,272,273]$. 
The structures of phytotoxic and ester bond-free cyclic peptides, excluding cyclodipeptides from fungi, are shown in Figure 32. Two cyclic tetrapeptides named apicidin (429) and apicidin $\mathrm{D}_{2}$ (430) were isolated from Fusarium semitectum KCTC16676, which was isolated from soybean seeds. Both apicidin (429) and apicidin $\mathrm{D}_{2}(\mathbf{4 3 0})$ showed inhibition on seedling growth of six plant species including maize, cucumber, lettuce, soybean, tomato, and wheat [274].

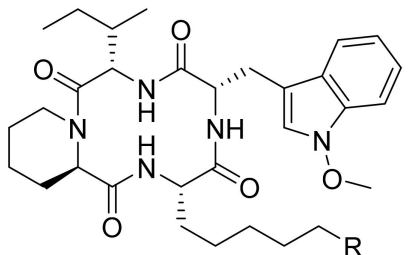

429. Apicidin, $\mathrm{R}=\mathrm{COCH}_{2} \mathrm{CH}_{3}$ 430. Apicidin $\mathrm{D}_{2}, \mathrm{R}=\mathrm{CH}(\mathrm{S}-\mathrm{OH}) \mathrm{CH}_{2} \mathrm{CH}_{3}$<smiles>CNC(=O)[C@H](CCCCCC(=O)[C@H](C)O)NC(=O)[C@@H]1CCCN1C(=O)C(Cc1ccccc1)NC(=O)C(C)(C)C</smiles>

431. Cyclo[2-methylalanyl-_-phenylalanyl-o-prolyl(2S,9R)-2-amino-9-hydroxy-8-oxodecanoyl]<smiles>CCC(C)[C@H](NC(=O)[C@H](Cc1ccc(OC)cc1)NC(=O)[C@H](CCCCCC(=O)C1CO1)NC(=O)C1CCCN1C(=O)[C@H]1CO1)C(=O)N1CCCO1</smiles>

432. Cyl-1<smiles>CCC(C)[C@H](NC(=O)[C@H](Cc1ccc(OC)cc1)NC(=O)[C@H](CCCCCC(=O)C1CO1)NC(=O)[C@@H]1CCCCN1C(=O)[C@H]1CO1)C(=O)N[C@@H]1CCCCN1</smiles>

433. Cyl-2<smiles>[R]C1NC(=O)[C@H](C)NC(=O)[C@@H]2[C@H]([R2])CCN2C(=O)[C@H](CCCCCC(=O)[C@@H]2CO2)NC1=O</smiles>

434. $H C$-toxin $\mathrm{I}, \mathrm{R}_{1}=\mathrm{CH}_{3}, \mathrm{R}_{2}=\mathrm{H}$ 435. HC-toxin II, $\mathrm{R}_{1}=\mathrm{H}, \mathrm{R}_{2}=\mathrm{H}$ 436. HC-toxin III, $\mathrm{R}_{1}=\mathrm{CH}_{3}, \mathrm{R}_{2}=\mathrm{OH}$

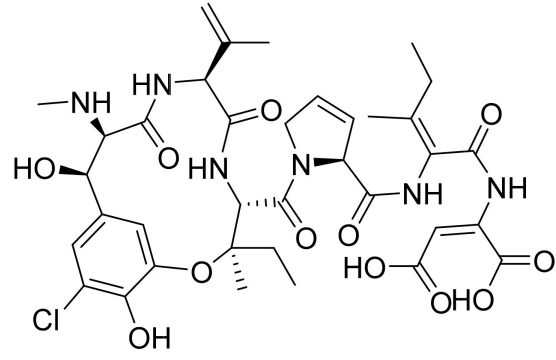

438. Phomopsin A<smiles>[R]C(=O)NC(CC(C)C(Cl)Cl)C(=O)N[C@H](C(=O)N[C@H]1C(=O)NC(=C)C(=O)N[C@@H](C(=O)O)CC2=C(C[C@H](O)C2=O)O[C@H]1C(C)C)[C@@H](O)CCCN</smiles>

437. $\mathrm{HV}$-toxin $\mathrm{M}, \mathrm{R}=\mathrm{CH}_{2} \mathrm{NH}_{2}$ 445. Victorin $\mathrm{C}, \mathrm{R}=\mathrm{CH}(\mathrm{OH})_{2}$<smiles></smiles>

439. Tentoxin<smiles>CNC(=O)C(CC(C)C)NC(=O)C(C)N(C)C(=O)CNC(=O)C(Cc1ccccc1)N(C)C</smiles>

440. Dihydrotentoxin<smiles>CNC(=O)C(CC(C)C)NC(=O)C(C)N(C)C(=O)CNC(=O)/C(=C\c1ccccc1)N(C)C(=O)C(C)C</smiles>

441. Isotentoxin<smiles>[R]C(NC(=O)[C@H](NC)[C@@H](O)c1cc(O[C@](C)(CC)C(NC(=O)[C@H](N)C[C@@H](O)C[C@@H](N)C(=O)O)C(=O)NCC(=O)O)c(O)cc1S(=O)O)C(=O)NC</smiles>

442. Ustiloxin $\mathrm{A}, \mathrm{R}=\mathrm{CH}\left(\mathrm{CH}_{3}\right)_{2}$

443. Ustiloxin $\mathrm{B}, \mathrm{R}=\mathrm{CH}_{3}$<smiles></smiles>

444. Ustiloxin G

Figure 32. Structures of the phytotoxic and ester bond-free cyclic peptides, excluding cyclodipeptides isolated from fungi. 
Cyclo[2-methylalanyl- L-phenylalanyl-D-prolyl- (2S,9R)-2-amino-9-hydroxy-8-oxodecanoyl] (431), a phytotoxic cyclotetrapeptide, was isolated from the culture broth of Verticillium coccosporum. This metabolite was toxic to Lemna minor [275].

Cyl-1 (432) and Cyl-2 (433) from the culture broth of Cylindrocladium scoparium, the pathogen of many higher plant diseases, inhibited root growth of lettuce seedlings [276]. Phytotoxic Cyl-1 (432) and Cyl-2 (433) were previously isolated from C. scoparium, respevtively $[277,278]$

HC-toxin I (also called HC-toxin, 434) was a host-specific phytotoxin produced by Helminthosporium carbonum (syn. Cochliobolus carbonum), the pathogen to cause necrotic lesions on maize leaves [279]. HC-toxins II (435) and III (436) along with HC-toxin I (434) were latter isolated from $H$. victoriae. These three HV-toxins were considered as the host-specific toxins to show root growth inhibition on the susceptible maize seedlings [280].

HV-toxin M (437) was another host specific phytotoxin isolated from the culture broth of Helminthosporium victoriae, the causal agent of victoria blight disease of oat [281].

Phomopsin A (438) was a cyclic tripeptide with a tripeptide side chain isolated from Phomopsis leptostromiformis. This compound inhibited seedling growth of lupinis [282,283].

Tentoxin (439) and dihydrotentoxin (440) were isolated from the culture filtrates of Alternaria alternata. Both metabolites caused distinct wilting of the cuttings of weed Galium aparine [284-286]. Tentoxin (439) was also isolated from the cultures of Alternaria linicola, the seed-borne pathogen of linseed (Linum usitatissimum) by causing poor germination and damping-off of the seedlings [256]. Isotentoxin (441), the $E$-isomer of tentoxin (439), was produced from tentoxin (439) by UV-irradiation. The transformed isotentoxin had stronger wilting effects against the weed Galium aparine than tentoxin $(439)[285,286]$.

Ustiloxins A (442), B (443) and G (444) were isolated from Ustilaginoidea virens (teleomorph: Villosiclava virens), the pathogen of rice false smut disease. They showed strong inhibition on the radicle and germ elongation of rice seedlings. When their concentrations were at $200 \mu \mathrm{g} / \mathrm{mL}$, the inhibitory ratios of radicle and germ elongation were more than $90 \%$ and $50 \%$, respectively, the same effect as that of positive control (glyphosate). They also induced abnormal swelling of the roots and germs of rice seedlings [267].

Victorin C (445) was a host-specific phytotoxin from Cochliobolus victoriae (syn. Helminthosporium victoria), the causal agent of victoria blight of oats [287].

\subsection{Noncyclic Oligopeptides}

Fungal phytotoxic noncyclic oligopeptides are linear compounds composed of several amino acids (Figure 33). AS-I toxin (446) was a phytotoxic tetrapeptide (Ser-Val-GlyGlu) isolated from the culture filtrates of Alternaria alternata, the pathogen of sunflower (Helianthus annuus) by causing leaf necrotic spots. AS-I toxin (446) was toxic to sunflower. Nontoxic or very slight toxic effects were observed on the other tested plants which indicated that AS-I toxin (446) was a host-specific phytotoxin [288].

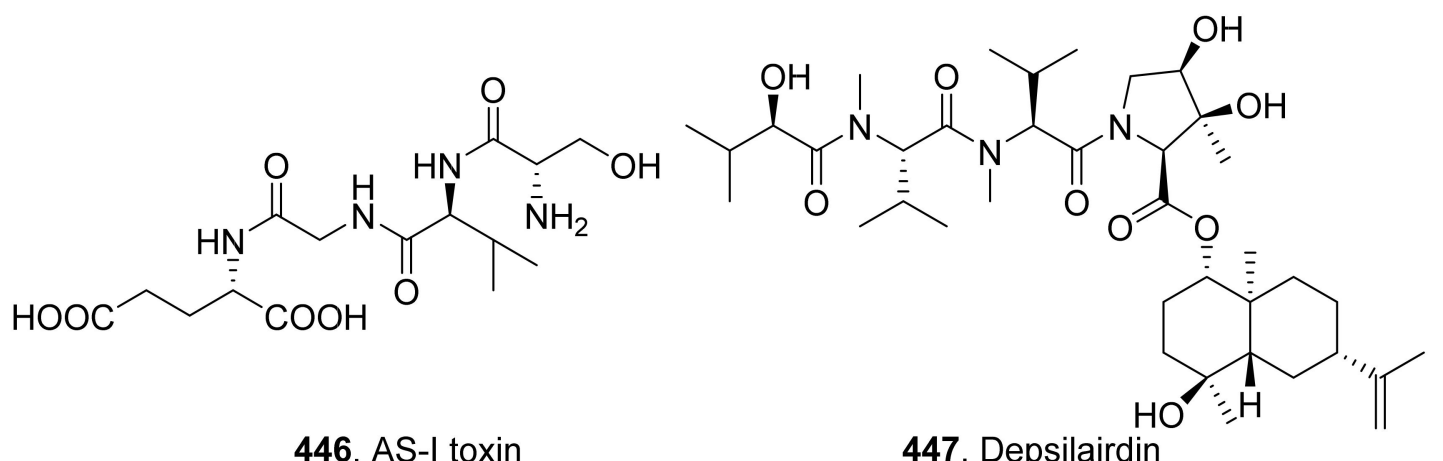

446. AS-I toxin 447. Depsilairdin

Figure 33. Structures of the phytotoxic noncyclic oligopeptides isolated from fungi. 
Depsilairdin (447) produced by Leptosphaeria maculans possessed a tripeptide coupled with a sesquiterpene moiety. Depsilairdin (447) caused disease symptoms similar to those caused by the pathogen. Plant leaves of brown mustard treated with depsilairdin (447) showed strong necrotic and chlorotic lesions, but such symptoms were not observed in canola at a wide concentration range from $1 \mu \mathrm{M}$ to $1 \mathrm{mM}$ [289].

\subsection{Cytochalasin Congeners}

Cytochalasins belong to class of perhydroisoindolylamcrocylclic lactones. The structures of phytotoxic cytochalasin congeners from fungi are shown in Figure 34. Cytochalasin B (448) was isolated from the culture filtrates of the plant pathogens Drechslera wirrenganensis and D. campanulata, and was toxic to the leaves of faba bean by leaf puncture assay [290].

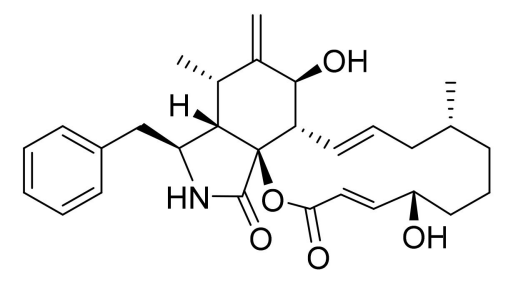

448. Cytochalasin B

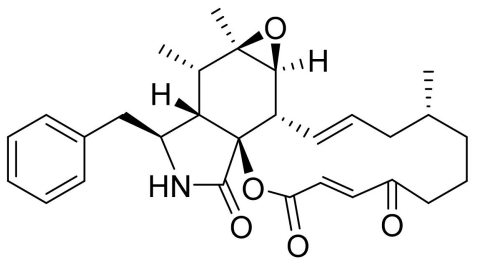

451. Cytochalasin F

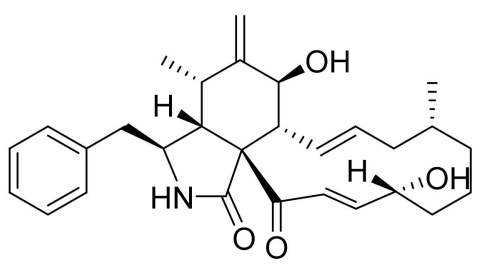

454. Deoxaphomin<smiles>CC(=O)O[C@H]1/C=C/[C@@](C)(O)C(=O)[C@@H](C)C/C=C/[C@H]1[C@]12C(=O)N[C@H](Cc3ccccc3)[C@H]1C(C)=C(C)[C@H](O)[C@H]2C</smiles>

449. Cytochalasin $C$

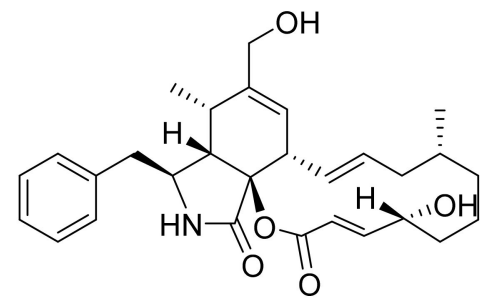

452. Cytochalasin Z2

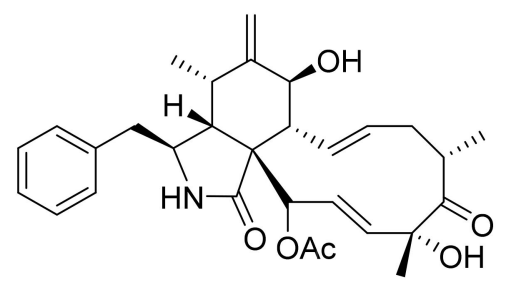

450. Cytochalasin D

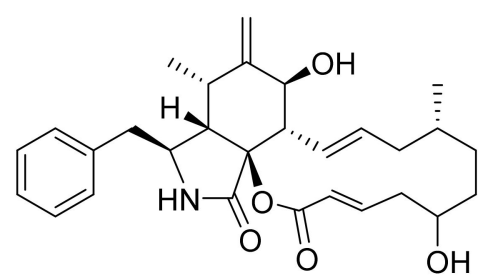

453. Cytochalasin Z3

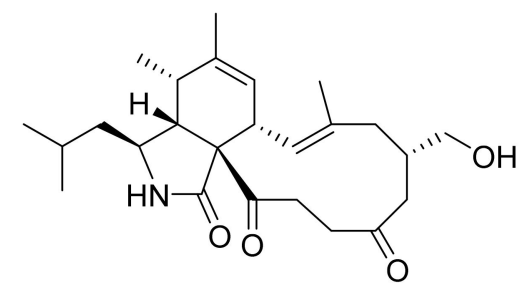

455. Phomacin $D$<smiles>CC1=C[C@H](/C=C(\C)C[C@@H](CO)CC(=O)C(=O)CC(=O)[C@@]23C=C(C)[C@H](C)[C@@H]2[C@@H](CC(C)C)NC3=O)[C@H](C)C(C)=C1</smiles>

456. Phomacin E<smiles>CC(=O)C[C@H]1CC(=O)C[C@@H](CO)C/C(C)=C/[C@H]2C=C(C)[C@@H](C)[C@H]3[C@H](CC(C)C)NC(=O)[C@@]23C(=O)N1</smiles>

457. Phomacin F

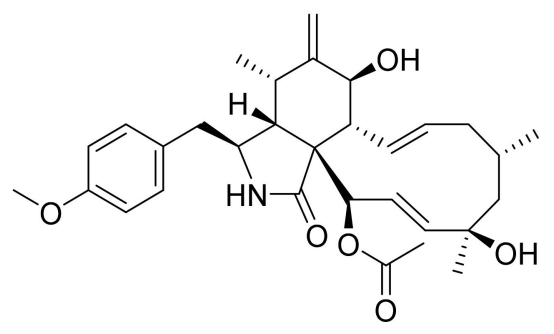

458. Pyrichalasin $\mathrm{H}$

Figure 34. Structures of the phytotoxic cytochalasins isolated from fungi.

Cytochalasins C (449) and D (450) were isolated from the endophytic fungus Xylaria cubensis associated with Eugenia brasiliensis (Myrtaceae). Both cytochalasins showed phytotoxic activity on wheat coleoptiles [291]. Cytochalasin D (450) was also isolated from the 
culture filtrates of Ascochyta rabiei (teleomorph: Didymella rabiei), the pathogen of chickpea. This metabolite was toxic to the leaflet cells of chickpea [292].

Five cytochalasin analogues named cytochalasins B (448), F (451), Z2 (452), Z3 (453) and deoxaphomin (454) were isolated from the Phoma exigua var. exigua (syn. Ascohyta sonchi), the leaf pathogen of Cirlum arvense and Sonchus arvensis. These cytochalasin analogues were all toxic to the leaves of Cirlum arvense and Sonchus arvensis by leaf diskpuncture assay [293].

Three cytochalasins named phomacins D (455), E (456) and F (457) were identified from the wheat pathogen Parastagoospora nodorum by genomics-driven discovery. Both phomacins D (455) and E (456) obviously inhibited wheat seed germination at $100 \mu \mathrm{g} / \mathrm{mL}$. Phomacin F (457) just had week inhibitory activity on wheat seed germination. Interestingly, phomacin D (455) did not show any inhibition of seed germination against the dicots Arabidopsis thaliana and Lepidium sativum, which indicated that seed germination inhibition of phomacin D (455) could be specific to monocots [294].

Pyrichalasin H (458) was isolated from the cultures of Pyricularia grisea, the causative fungus of blast disease in crabgrass (Digitaria sanguinalis). This compound strongly inhibited growth of rice seedlings at $1 \mu \mathrm{g} / \mathrm{mL}$ [295].

\subsection{Lactams}

The structures of phytotoxic lactams from fungi are shown in Figure 35. Cichorine (459), zinnimidine (485) and Z-hydroxyzinnimidine (486) were isolated from the fungus Alternaria cichorii, the pathogen of foliar blight disease of Russian knapweed (Acroptilon repens). These compounds were toxic to the leaves of Russian knapweed by in vitro leaf puncture assay [185].

Two apple fruit rot toxins namely FRT-A (also called sapinopyridione, 461) and FRT-B (also called flavipucine, 462) were isolated from Botryosphaeria berengeriana (anamorph: Macrophoma sp.). Both compounds were isomers and showed necrosis-inducing activity on apple fruits by dropping assay [296]. FRT-A (461) was also found in Sphaeropsis sapinea, the fungal pathogen of conifers occurring world-wide. It was toxic to three cypress species (Cupressus arizonica, C. macrocarpa, and C. sempervrens) by cutting twig assay [297]. The 3:1 mixture of FRT-A (461) and FRT-B (462) showed strong phytotoxic activity to plants bentgrass (Agrostis stolonifera) and lettuce (Lactuca sativa) by seedling growth assay [298].

Five metabolites named circinatin (460), periconins A (463) and B (464), and peritoxins A (465) and B (466) were isolated from the culture broth of Periconia circinata. Peritoxins A (465) and B (466) inhibited root growth of the susceptible genotype of sorghum by $50 \%$ at 1-4 ng/mL. Periconin A (463) showed weak inhibition on sorghum root growth, and no activity could be detected for circinatin (460) and periconin B (464) [299].

Four oxazatricycloalkenones phyllostictines A (467), B (468), C (469) and D (470) isolated from Phyllosticta cirsii showed phytotoxic to Cirsium arvense. Phyllostictine A (467) was proved to be highly toxic. Phyllostictines B (468) and D (470) were slightly less toxic compared to phlyllostictine A (467), wheras phyllostictine C (469) was almost not toxic, that showed a clear structure-activity relationship between the phytotoxic activity and the structural features characterizing phyllostictine group. Phyllostictine A (467) should be potential mycoherbicide for Cirsium arvense biocontrol [300]. 
<smiles>COc1c(C)c(O)cc2c1CNC2=O</smiles>

459. Cichorine<smiles>CCC/C=C/[C@H](CC(=O)O)CC(=O)N[C@@H](CC(=O)O)C(=O)N[C@H]1CCCCNC1=O</smiles>

460. Circinatin<smiles>CCC(C)C(=O)C1OC12C(=O)C=C(C)NC2=O</smiles>

461. FRT-A<smiles>CC1=CC(=O)C2(OC2C(=O)CC(C)C)C(=O)N1</smiles>

462. FRT-B

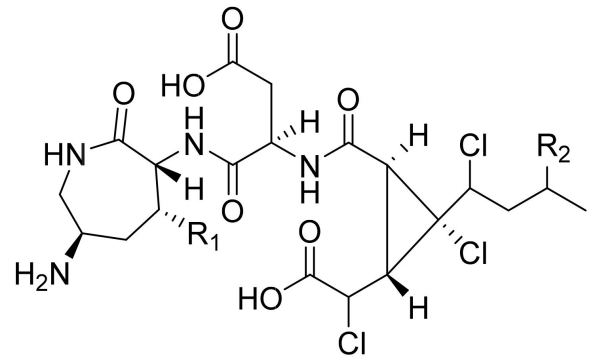

463. Periconin $\mathrm{A}, \mathrm{R}_{1}=\mathrm{H}, \mathrm{R}_{2}=\mathrm{OH}$

465. Peritoxin $A, R_{1}=R_{2}=O H$

466. Peritoxin $B, R_{1}=O H, R_{2}=H$<smiles>CC(O)CC(Cl)C1(Cl)[C@@H]2C(Cl)[C@@H]1C2C(=O)N[C@@H](CC(=O)O)C(=O)N[C@]1(C)CCC(CN)(CN)NC1=O</smiles>

464. Periconin B<smiles>CCN1C(=O)C2=C3CO[C@@](OC)([C@H]3O)[C@H](O)CCCCC[C@@]21C</smiles>

467. Phyllostictine A

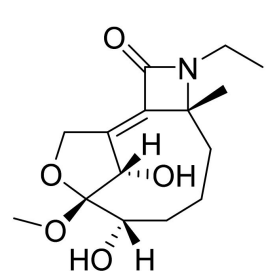

468. Phyllostictine B

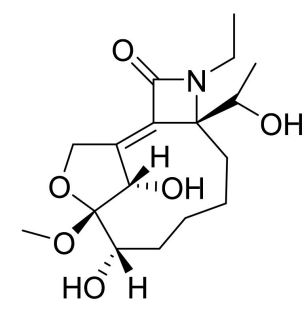

469. Phyllostictine $C$

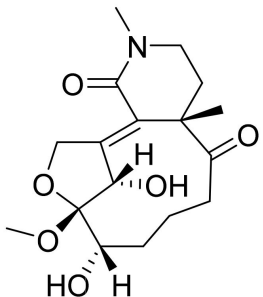

470. Phyllostictine D<smiles>[R]CCN1Cc2c(cc(OCC=C(C)C)c(C)c2OC)C1=O</smiles>

471. Porritoxin, $\mathrm{R}=\mathrm{OH}$

472. Porritoxin sulfonic acid, $\mathrm{R}=\mathrm{SO}_{3} \mathrm{H}$<smiles>CC/C=C\[C@H](O)[C@@H](O)C1=C(C)C(=O)[C@@]2(OC1=O)[C@@H]1NC(=O)[C@]2(OC)[C@H](c2ccccc2)O1</smiles>

473. Pseurotin A<smiles></smiles>

474. Spirostaphylotrichin A
475. Spirostaphylotrichin $\mathrm{C}, \mathrm{R}_{1}=\mathrm{OH}, \mathrm{R}_{2}=\mathrm{H}$ 476. Spirostaphylotrichin $D, R_{1}=H, R_{2}=O H$<smiles>[R7]C1([R17])C(=O)C=CC2(CCC)C(=O)C(O)(O)N(OC)C12C(=O)O</smiles>

477. Spirostaphylotrichin $R$,

$$
\mathrm{R}_{1}=\mathrm{H}, \mathrm{R}_{2}=\mathrm{OH}
$$

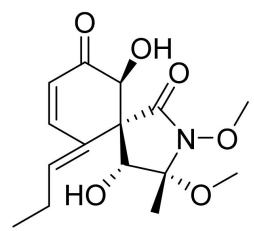

478. Spirostaphylotrichin $\mathrm{V}$<smiles>CCCC1C=CC(=O)C(O)C12C(=O)N(OC)[C@@](C)(OC)C(O)(OC)C2O</smiles>

479. Spirostaphylotrichin W<smiles>CC[C@H](C)[C@]1(C)NC(=O)C(C(C)=O)=C1O</smiles>

480. Tenuazonic acid<smiles>C=C1C(=O)C2(CCCC)C(=C)C(=O)C=CC2(O)C(=O)N1OC</smiles>

481. Triticone A<smiles>C=C1C(=O)C2(CCCC)C=CC(=O)[C@H](O)[C@@]2(O)C1ONC</smiles>

482. Triticone B<smiles>C/C=C(\C)CC(C)CC(C)/C(O)=C1\C(=O)NC(C(O)c2ccc(O)cc2)C1=O</smiles>

484. Vancouverone $B$<smiles>[R]C/C(C)=C\COc1cc2c(c(OC)c1C)CNC2=O</smiles>

485. Zinnimidine, $\mathrm{R}=\mathrm{H}$

486. $Z$-Hydroxyzinnimidine, $\mathrm{R}=\mathrm{OH}$

Figure 35. Structures of the phytotoxic lactams isolated from fungi. 
Porritoxin (471) was first identified as a benzoxazocine derivative from the culture broth of Alternaria porri, the causal pathogen of black spot disease in stone-leek and onion [301]. The structure of porritoxin (471) was then corrected as isoindol-1-one congener [302]. This compound inhibited shoot and root growth of lettuce seedlings at $10 \mu \mathrm{g} / \mathrm{mL}$ [301]. Another isoindo-1-one, namely porritoxin sulfonic acid (472) was later isolated from $A$. porri. Structure-phytotoxicity investigation showed that the $N$-alkyl and hydroxyl groups contributed to the phytotocitiy, but that this activity became weak with sulfonation [286].

Pseurotin A (473) was produced by Ascochyta lentis. This metabolite was phytotoxic to lentil (Lens culinaris), and was light-dependent [87].

Spirostaphylotrichins A (474), C (475), D (476), R (477), V (478) and W (479) as well as triticone E (483) were isolated from Pyrenophora semeniperda (anamorph: Drechelera sp.), the seed pathogen of cheatgrass (Bromus tectorum). This compound was toxic to the leaves of wheat, tomato, sowthistle and cheatgrass [303].

Tenuazonic acid (also called TeA, TA, and AAC-toxin, 480) was a tetramic acid phytotoxin which was isolated from a series of Alternaira fungi such as A. alternata [304], $A$. citri [305], A. crassa [306], A. linicola [256], A. tenuissima [307]. This compound was also produced by other plant pathogenic fungi such as Magnaporthe oryzae [308] and Phoma sorghina [309]. Tenuazonic acid (480) was found to inhibit photosynthesis with the target site as photosystem II (PSII) [310-312]. Therefore, tenuazonic acid (480) was considered as the potential herbicide [304,313].

Triticones A (481) and B (482) were two spirocyclic $\gamma$-lacams isolated from Drechslera tritici-repentis, the causal agent of reddish brown spots on wheat (Triticum vulgare). Two compounds in mixture showed phytotoxicity on the leaves and protoplasts of wheat [314].

Vancouverone B (484) was isolated from a sea snail-derived fungus, Penicillium vancouverense YY-1. This metabolite exhibited inhibition on the seedling root growth of Lactuca sativa, Trifolium repens, Rahanus sativus var. longipinnatus, and Brassica rapa var. perviridis [315].

\subsection{Indole Derivatives}

The structures of phytotoxic indole derivatives from fungi are shown in Figure 36. Chlamydosporin (487) was isolated from the endophytic fungus Fusarium chlamydosporum residing in the roots of Suaeda glauca. This indole derivative exhibited significant phytotoxic activity against the radicle growth of Echinochloa crusgalli seedlings with the inhibition rate of more than $80 \%$, even at concentration of $1.25 \mu \mathrm{g} / \mathrm{mL}$ [316].<smiles>C[C@H](O)[C@H](C)OC(=O)Cc1c[nH]c2ccccc12</smiles>

487. Chlamydosporin<smiles>CC1=C(C)C(=O)C(C2Nc3ccccc3C2(C)O)C(=O)O1</smiles>

488. Coletopyrandione<smiles>COC(=O)[C@H](O)Cc1c[nH]c2ccccc12</smiles>

489. Crypticin C<smiles>OCCc1c[nH]c2ccccc12</smiles>

490. Tryptophol

Figure 36. Structures of the phytotoxic indole derivatives isolated from fungi.

Colletophyrandione (488) was a tetrasubstituted indolyllidenepyrandioine isolated from the culture filtrates of Colletotrichum higginsianum. It was toxic to four plant species Sonchus arvensis, Helianthus annuus, Convolulus arvensis, Ambrosia artemisiifolia by leaf puncture assay [317].

Crypticin C (489) was isolated from the culture filtrates of Diaporthella cryptica, the emerging hazelnut pathogen. This compound was active in the tomato cutting assay [173].

Tryptophol (490) was isolated as a major metabolite from the cultures of Drechslera nodulosum (syn. Helminthosporium nodulosum), the pathogen of seedling blight of goosegrass (Eleusine indica). This metabolite caused necrotic lesions on goosegrass at $6.2 \times 10^{-4} \mathrm{M}$ [318]. 


\subsection{Pyridine Derivatives}

The structures of phytotoxic pyridine derivatives from fungi are shown in Figure 37. Ascosonchine (491) was the enol tautomer of 4-pyridylpyruvic acid with herbicidal activity produced by Ascohyta sonchi, the leaf pathogen of Sonchus arvensis, a perennial herbaceous weed occurring throughout the temperate regions of the world. Ascosonchine (491) was toxic to Sonchus arvensis and showed selective herbicidal properties [319].

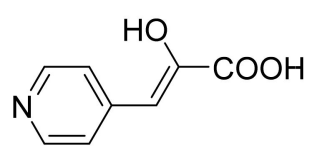

491. Ascosonchine<smiles>CCCCc1ccc(C(=O)O)nc1</smiles>

492. Fusaric acid<smiles>C=CCCc1ccc(C(=O)O)nc1</smiles>

493. 9,10-Dehydrofusaric acid<smiles>CC(C)(C)O[Mg]O[Mg]</smiles>

chlorofusaric acid<smiles>[R]C(C)CCc1ccc(C(=O)OC[C@@H](O)CO)nc1</smiles>

495. Fusaricate $A, R=H$ 496. Fusaricate $B, \mathrm{R}=\mathrm{OH}$
497. Fusaricate C
498. Fusaricate $\mathrm{D}, 3^{\prime} R$

499. Fusaricate $E, 3^{\prime} S$<smiles>C=CCCc1ccc(C(=O)OC[C@H](O)[C@H](O)[C@H](O)CO)nc1</smiles>

500. Fusaricate $F, 3^{\prime} R$ 501. Fusaricate $G, 3^{\prime} S$<smiles>[R]C1CC12C(OC)=CC(C(C)=O)=CN2C</smiles>

502. Luteoethanone $A, R=\mathrm{CH}_{3}$ 503. Luteoethanone $B, \mathrm{R}=\mathrm{H}$<smiles>OCC(c1cccnc1)C(CO)c1cccnc1</smiles>

504. Spencertoxin

Figure 37. Structures of the phytotoxic pyridine derivatives isolated from fungi.

Fusaric acid (also called 5-butylpicolinic acid, 492) was isolated from Fusarium oxysporum. It was toxic to tobacco leaves by pucture assasy [320]. Fusaric acid (492) was produced by several Fusarium species which commonly infected cereal grains and other agricultural commodities [321]. Both fusaric aicd (492) and 9,10-dehydrofusaric acid (493) were isolated from Fusarium nygamai, which caused large leaf and stem necrosis on the host Striga hermonthica. These two compounds showed a wide chlorosis and necrosis in the punctured aera of tomato leaves as well as a strong inhibition on root elongation of tomato seedlings [322].

The endophytic fungus Fusarium oxysporum from the fruits of Drepanocarpus lunatus affored eight new fusaric acid derivatives, 10-hydroxy-11-chlorofusaric acid (494), and fusaricates A-G (495-501). All isolated fusaric acid derivatives showed significant phytotoxicity to the leaves of barley [323].

Luteoethanones A (502) and B (503), two 1-substituted ethanones, were isolated from Neofusicoccum luteum, the causal agent of Botryosphaeria dieback on grapevine. Both metabolites caused large necrotic spots, severe shriveling, and distortion of the leaf lamina of grapevine by leaf detached assay [39].

Spencertoxin (504), a dipyridine-butane-1,4-diol derivative, was isolated from Spencermartinsia viticola, the causal agent of Botryosphaeria dieback on grapevine in Australia. Spencertoxin (504) showed phytotoxicity on Vitis lambrausca and V. vinifera cv. Shiraz by grapevine leaf assay [163]. 


\subsection{Amines and Noncyclic Amides}

Phytotoxic amines and noncyclic amides are the common nitrogen-containing metabolites produced by fungi. Their structures are shown in Figure 38. Ten AAL toxins, $\mathrm{TA}_{1}(\mathbf{5 0 5})$, $\mathrm{TA}_{2}$ (506), $\mathrm{TB}_{1}$ (507), $\mathrm{TB}_{2}$ (508), $\mathrm{TC}_{1}$ (509), $\mathrm{TC}_{2}$ (510), $\mathrm{TD}_{1}(511), \mathrm{TD}_{2}(512), \mathrm{TE}_{1}(513)$, and $\mathrm{TE}_{2}$ (514), were isolated from Alternaria alternata f.sp. lycopersici, the pathogen of tomato stem canker disease [324-326]. These metabolites consisted of tricarballylic acid esters at either $\mathrm{C}_{13}$ or $\mathrm{C}_{14}$ of an amino polyol backbone. They were toxic to all tissures of tomato cultivars at low concentrations and induced apoptosis in sensitive tomato plants [327]. They were considered as the host-specific toxins (HSTs) as they were toxic to host plants and had lower phytotoxicity to non-host plants. Further action mechanism study showed these AAL toxins inhibited de novo sphingolipid (or called ceramide) biosynthesis of tomato. Therefore, AAL toxins were called sphinganine-analog mycotoxins (SAMs) [328].<smiles>[R6]NCC(O)CC([R])C([R3])CCCCCC(C)CC(O[R6])C(O[R17])C(C)CC</smiles>

505. AAL toxin $T A_{1}, R_{1}=H, R_{2}=\mathrm{CO}-\mathrm{CH}_{2}-\mathrm{CH}(\mathrm{COOH})-\mathrm{CH}_{2}-\mathrm{COOH}, \mathrm{R}_{3}=\mathrm{OH}, \mathrm{R}_{4}=\mathrm{OH}, \mathrm{R}_{5}=\mathrm{H}$ 506. AAL toxin $\mathrm{TA}_{2}, \mathrm{R}_{1}=\mathrm{CO}-\mathrm{CH}_{2}-\mathrm{CH}(\mathrm{COOH})-\mathrm{CH}_{2}-\mathrm{COOH}, \mathrm{R}_{2}=\mathrm{H}, \mathrm{R}_{3}=\mathrm{OH}, \mathrm{R}_{4}=\mathrm{OH}, \mathrm{R}_{5}=\mathrm{H}$ 507. AAL toxin $\mathrm{TB}_{1}, \mathrm{R}_{1}=\mathrm{H}, \mathrm{R}_{2}=\mathrm{CO}-\mathrm{CH}_{2}-\mathrm{CH}(\mathrm{COOH})-\mathrm{CH}_{2}-\mathrm{COOH}, \mathrm{R}_{3}=\mathrm{H}, \mathrm{R}_{4}=\mathrm{OH}, \mathrm{R}_{5}=\mathrm{H}$ 508. AAL toxin $T B_{2}, R_{1}=\mathrm{CO}-\mathrm{CH}_{2}-\mathrm{CH}(\mathrm{COOH})-\mathrm{CH}_{2}-\mathrm{COOH}, \mathrm{R}_{2}=\mathrm{H}, \mathrm{R}_{3}=\mathrm{H}, \mathrm{R}_{4}=\mathrm{OH}, \mathrm{R}_{5}=\mathrm{H}$ 509. AAL toxin $\mathrm{TC}_{1}, \mathrm{R}_{1}=\mathrm{H}, \mathrm{R}_{2}=\mathrm{CO}-\mathrm{CH}_{2}-\mathrm{CH}(\mathrm{COOH})-\mathrm{CH}_{2}-\mathrm{COOH}, \mathrm{R}_{3}=\mathrm{H}, \mathrm{R}_{4}=\mathrm{H}, \mathrm{R}_{5}=\mathrm{H}$ 510. AAL toxin $\mathrm{TC}_{2}, \mathrm{R}_{1}=\mathrm{CO}-\mathrm{CH}_{2}-\mathrm{CH}(\mathrm{COOH})-\mathrm{CH}_{2}-\mathrm{COOH}, \mathrm{R}_{2}=\mathrm{H}, \mathrm{R}_{3}=\mathrm{H}, \mathrm{R}_{4}=\mathrm{H}, \mathrm{R}_{5}=\mathrm{H}$ 511. AAL toxin $T_{1}, R_{1}=H, R_{2}=C O-C_{2}-C H(C O O H)-C_{2}-\mathrm{COOH}, R_{3}=H, R_{4}=O H, R_{5}=\mathrm{COCH}_{3}$ 512. AAL toxin $T_{2}, R_{1}=\mathrm{CO}-\mathrm{CH}_{2}-\mathrm{CH}(\mathrm{COOH})-\mathrm{CH}_{2}-\mathrm{COOH}, \mathrm{R}_{2}=\mathrm{H}, \mathrm{R}_{3}=\mathrm{H}, \mathrm{R}_{4}=\mathrm{OH}, \mathrm{R}_{5}=\mathrm{COCH}_{3}$<smiles>CC(=O)NC1C=CC(=O)O1</smiles>

515. Acetamido butenolide

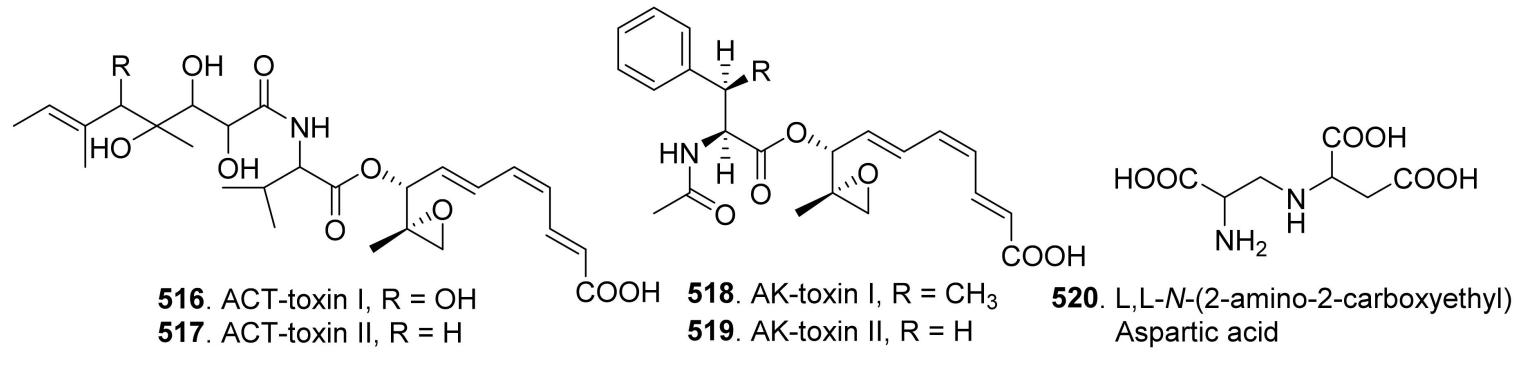<smiles>NC(CC1CNC(C(=O)O)[C@@H](CC(=O)O)C1=O)C(=O)O</smiles>

521. Anhydroaspergillomarasmine $A$<smiles>NC(CNC(CNC(CCC(=O)O)C(=O)O)C(=O)O)C(=O)O</smiles>

522. Aspergillomarasmine $A$<smiles>CC(=O)NC(C(=O)O)[C@H](C)c1ccccc1</smiles>

527. N-Acetyl- $\beta$-methylL-phenylalanine<smiles>C/C=C/C1=C(C(=O)NC(C(=O)O)C(C)CC)[C@H]2CCC(=O)[C@H]2[C@H]1OC</smiles>

523. Cinnacidin

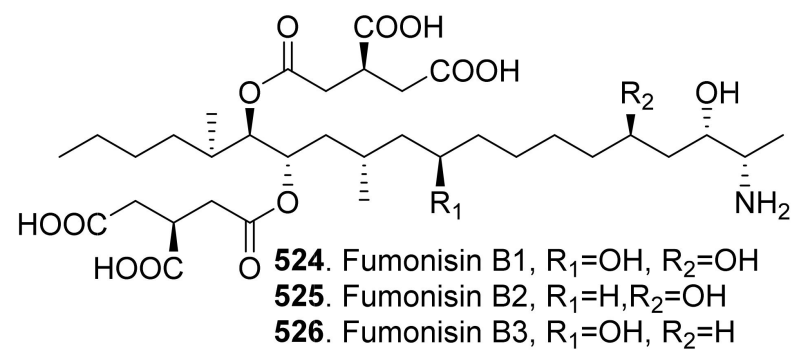<smiles>C[C@H]1C=C[C@H]2CCCC[C@]2(Cc2cc(NCCO)c(C=O)c(=O)o2)[C@@H]1C</smiles>

528. Solanapyrone $C$

Figure 38. Structures of the phytotoxic amines and noncyclic amides isolated from fungi. 
Acetamido-butenolide (515) was isolated from Fusarium avenaceum, the pathogen of spotted knapweed (Centaurea maculosa), acted synergistically with enniatin B (402) to cause necrotic lesions on leaves of different plant species [262].

ACT-toxins I (516) and II (517) were isolated from Alternaria citri (previously as A. alternata), the pathogen of tangerines and mandarins (Citrus reticulata). They were also host-specific toxins [329].

AK-toxins I (518) and II (519), another two host-specific toxins, were isolated from Alternaria kikuchiana (previously as A. alternata), the pathogen of either apple leaf spot disease or Japanese pear black spot disease [330].

L,L-N-(2-amino-2-carboxyethyl) aspartic acid (520), anhydroaspergillomarasmine A (521) and aspergillomarasmine A (522) were isolated as phytotoxic metabolites from the liquid culture of Pyrenophora teres (anamorph: Drechslera teres, syn: Helminthosporium teres), the causal agent of net bloch of barley, a serious disease common in humid and temperate climates. Tested on detached barley leaves, L,L-N-(2-amino-2-carboxyethyl) aspartic acid (520), and aspergillomarasmine A (522) induced chlorotic and necrotic symptoms, while only aspergillomarasmine A (522) showed weak phytotoxicity [331].

Cinnacidin (523), a cyclopentalenne-isoleucine, was isolated from Nectria sp. This metabolite inhibited the root growth of Arabidopis thaliana and bentgrass seedlings [332].

Fumonisins B1 (FB1, 524), B2 (FB2, 525), and B3 (FB3, 526) were isolated from the cultures of Fusarium moniliforme. They were long-chain polyhydroxyl alkylamines with two propane tricarboxylic acid moieties esterified to hydroxyls on adjacent carbons. These compounds inhibited seedling growth of corn and tomato [333].

$N$-Acetyl- $\beta$-methyl-L-phenylalanine (527) was isolated from Villosiclava virens (anamorph: Ustilaginoidea virens), the pathogen of rice false smut disease. It inhibited rice radicle elongation [334].

Solanapyrone C (528) has been isolated from the culture filtrate of Alternaria solani, the causal organism of early blight disease of tomato and potato [132], and the culture filtrates of Ascochyta rabiei, the pathogen of chickpea [133]. Solanapyrone C (528) was toxic to the leaves of the host plants.

\subsection{Other Nitrogen-Containing Metabolites}

The structures of other fungal phytotoxic nitrogen-containing metabolites are shown in Figure 39. Brasicicolin A (529) was isolated from Alternaria brassicola, the dark leaf spot pathogen of Brassica species. Brasicicolin A (529) was a polyester of mannitol esterified with two $\alpha$-isocyanoisopentanoyl, two $\alpha$-hydroxyisopentanoyl and two acetyl residues. It was a mixture of diastereomers due to the epimerizable protons adjacent to the isocyano group. Brasicicolin A (529) was host specific phytotoxin by causing chlorosis and necrosis on the leaves of brown mustard (Brassica juncea cv. Cutlass, susceptible) at $0.5 \mathrm{mM}$, but no detectable damage on the leaves of white mustard (Sinapis alba cv. Ochre, resistant) [335].

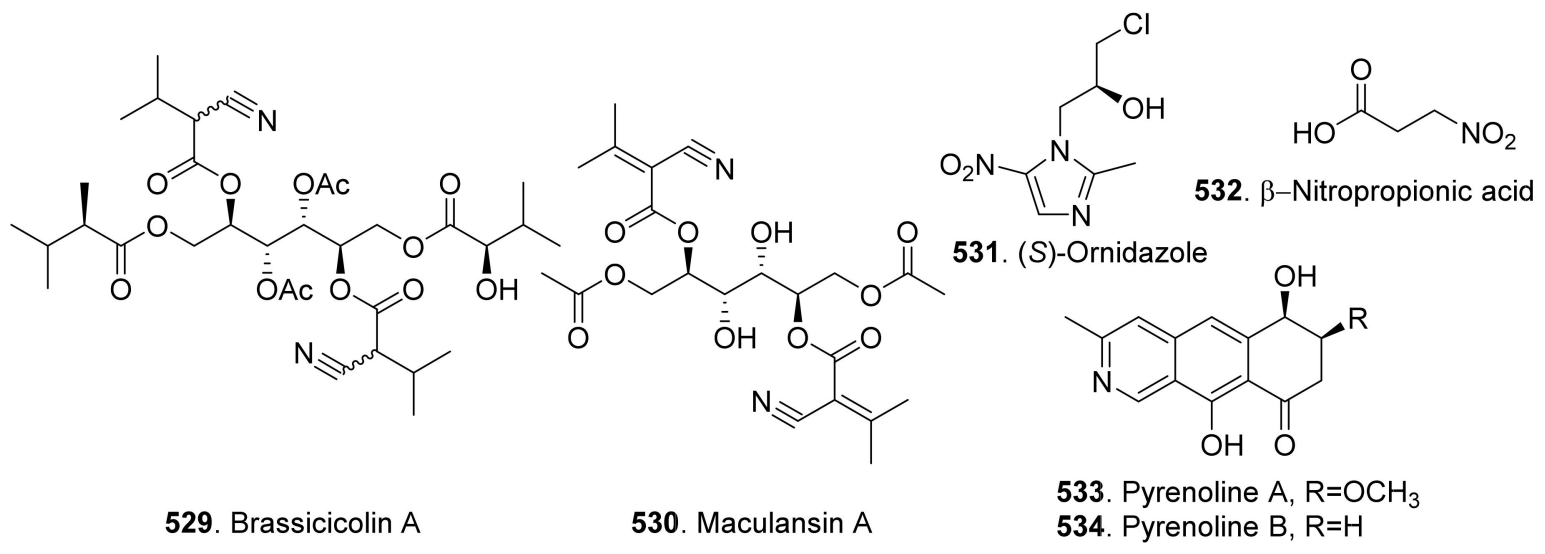

Figure 39. Structures of the other phytotoxic nitrogen-containing metabolites isolated from fungi. 
Maculansin A (530) was isolated from Leptosphaeria maculans (anamorph: Phoma lingam) cultured in potato dextrose broth (PDB) at high temperature. The structure of maculansin A (530) was similar to that brasicicolin A (529). Maculansin A (530) was more toxic to resistant plant (brown mustard) than to susceptible plant (canola) [167].

(S)-Ornidazole (531), a nitroimidazole, was isolated from the solid culture of Penicillium purpurogenum derived from soil. This compound inhibited root and hypocotyl growth of radish seedlings at $100 \mu \mathrm{M}$ [26].

$\beta$-Nitropropionic acid (532) was isolated from Septoria cirsii, the pathogen of weed Canada thistle (Cirsium arvense) growing in virturally all temperate areas of the world. This compound inhibited seed germination and root elongation, and caused the typical symptoms of chlorosis and necrosis on the leaves of Canada thistle and other test plants [336].

Two isoquinoline derivatives named pyrenolines A (533) and B (534) were isolated from the cultures of Pyrenophora teres, the pathogen of barley. Both compounds were toxic to both monocots and dicots by leaf puncture assay [337].

\section{Miscellaneous}

The structures of miscellaneous phytotoxic metabolites from fungi are shown in Figure 40. Crypticin A (535), a phenylpropanoid, was isolated from the culture filtrates of Diaporthella cryptica, the pathogen of hazelnut. This compound was also called 2-hydroxy3-phenylpropanoate methyl ester. It was found to be inactive at $1 \mathrm{mg} / \mathrm{mL}$ on the leaves of cork oak, grapevine, hazelnut, and holm oak by leaf puncture assay [173].<smiles>COC(=O)[C@H](O)Cc1ccccc1</smiles><smiles>O=C1C(CO)=C[C@@H](O)[C@H]2O[C@H]12</smiles>

535. Crypticin A<smiles>C=Cc1ccccc1</smiles>

537. Guignardianone $\mathrm{C}, \mathrm{R}=\mathrm{CH}_{3}$ 538. 2'-Hydroxyethyl guignardate, $\mathrm{R}=\mathrm{CH}_{2} \mathrm{CH}_{2} \mathrm{OH}$

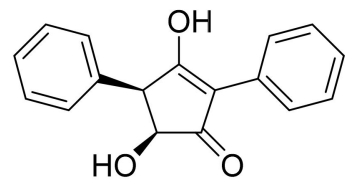

540. Phaseocyclopentenone A<smiles>O=C1C(c2ccccc2)=C(O)C(O)(C(=O)c2ccccc2)[C@@H]1O</smiles><smiles>[R]Cc1ccccc1</smiles>

542. Phenylacetic acid, $\mathrm{R}=\mathrm{COOH}$ 541. Phaseocyclopentenone B 543. Phenylethyl alcohol, $\mathrm{R}=\mathrm{CH}_{2} \mathrm{OH}$<smiles>C/C=C(C)/C=C/C1=C[C@@H](O)[C@H]2O[C@H]1C2=O</smiles><smiles>C=C(C)C#C[C@H]1[C@@H](O)C=C[C@@H](O)[C@H]1O</smiles>

545. Stagonosporyne G

Figure 40. Structures of the miscellaneous phytotoxic metabolites isolated from fungi.

Two cyclohexene epoxides named (+)-epiepoxydon (536) and PT-toxin (544) were isolated from Pestalotiopsis longiseta and P. theae. They induced leaf necrosis on the test leaves [338].

Guignardianone C (537), 2'-hydroxyethyl guignardate (538) and ethyl guignardate (539) were isolated from the endophytic fungus Phyllosticata capitalensis derived from Cephalotaxus fortune. These three compounds inhibited shoot and root growth of Lactuca sativa and Lolium perenne seedlings [21].

Phaseocyclopentenones A (540) and B (541) are penta- and tetrasubstituted cyclopentenones isolated from the culture filtrates of Macrophomina phaseolina, the charcoal rot pathogen of many crops. Both compounds were toxic to the non-host plant tomato (Solanum lycopersicum) by leaf puncture assay and seedling cutting assay. However, they did not show phytotoxic activity to the host plant soybean (Glycine max) [243]. 
Phenylacetic acid (542) was isolated from the liquid culture filtrates by Biscogniauxia mediterranea, the pathogen of cork oak (Quercus suber). This compound caused epinasty on cork oak cuttings, and wilting on non-host tomato [137].

Phenylethyl alcohol (543) was identified in the volatile organic compounds from the endophytic fungus Hypoxy anthochroum strain Blaci isolated from Bursera lancifolia (Burseaceae). This compound showed phytotoxic activity on seed germination, root elongation and seedling respiration of Amaranthus hypochondriacus, Panicum miliaceum, Trifolium pratense and Medicago sativa [186].

Stagonosporyne G (545) was an oxygenated acetylenic cyclohexanoid isolated from the Parastagonospora nodorum SN15, the pathogen of wheat. This compound displayed a significant phytotoxic activity by killing Arabidopsis thaliana seedlings [339].

\section{Conclusions and Future Perspectives}

Due to long-term co-evolution of pathogenic fungi and their host plants, the fungus has evolved strategies for successful infection of host. Among these strategies is the production of phytotoxins. Fungal phytotoxins play an important role in the process of pathogenesis as the mediators of virulenece [12]. They are either host specific or non-host specific. This is why many phytotoxins have been identified from phytopathogenic fungi. In fact, fungal phytotoxins play diverse roles in plant disease, from impacting symptom expression, disease progression, to being required for pathogenesis. Some phytotoxins are directly toxic by killing plant cells and allowing for infection of dead cells. Others interfere with the induction of defense responses, or induce programmed cell death-mediated defense responses in order to generate necrosis required for pathogenicity $[7,167,335]$.

In recent years, more and more phytotoxic metabolites have been discovered from other fungi such as plant and animal endophytic fungi, soil-derived fungi, and marinederived fungi $[21-24,27,28]$. Most of these phytotoxic metabolites are non-host specific. They are suitable for development of herbicides with a broad spectrum. In addition, the phytotoxins from weed pathogens are a very promising source of specific herbicide development for weed control $[25,340,341]$. An example of success is the discovery of ophiobolins which have shown their potential as herbicides [229,230].

Some isolated fungal phytotoxins can be used as the lead compounds, allowing more toxic compounds based on their structures to be chemically synthesized. An example of this is the synthesis of cinnacidin (523) analogs. Two new structural analogs of cinnacidin (523), namely $(2 S, 3 S)-2$ - [ $(3 R S, 3 a S R, 6 a R S)$-3- methoxy-4-oxo-3,3a,4,5,6,6a- hexahydropentalen-1ylcarbamoyl]- 3-methylvaleric acid and benzyl (2S,3S)-2-[(3RS,3aSR,6aRS)-3-methoxy-4oxo-3,3a,4, 5,6,6a-hexahydro pentalen-1-ylcarbamoyl]- 3-methylvalerate, have been synthesized. The synthetic compounds were highly phytotoxic on a range of weeds to show their potential application as herbicides [332].

Transformation of phytotoxin-resistant genes from the fungus into plants is another strategy. Aspterric acid (259) is a fungal phytotoxin. Aspterric acid-producing fungi have the self-resistance gene, astD, which was validated to be insensitive to aspterric acid (259). The fungal self-resistance gene $a s t D$ has been deployed as a transgene in the establishment of plants to create aspterric acid-resistant crops. Aspterric acid (259) should be a promising lead for development as a broad-spectrum commercial herbicide [189].

The current review describes the phytotoxic activities of secondary metabolites from fungi. In fact, many fungal phytotoxins have other biological activities in addition to their phytotoxic activity. For example, emodin (86) exhibits antioxidant [342], antitumor [343], phytotoxic [86], insecticidal [344], antimicrobial [344], and acetylcholinesterase (AChE) and glutathione $S$-transferase (GST) inhibitory [344] activities. In addition, many other isolated fungal metabolites have not been evaluated for their phytotoxic activities due to either the lack of phytotoxic assays or not enough of the compounds could be isolated to perform toxicity assays. These metabolites remain to be further tested for their phytotoxicities. For example, herbarin (47) is a naphthoquinone congener. It was previously isolated from a few 
fungal species such as Anteaglonium sp. FL0768 [345] and Corynespora sp. BA-10763 [346], and later showed obviously phytotoxic activity [59].

In addition to their potential as herbicides, fungal phytotoxins have other potential applications in agriculture [1]. As different fungal species produce specific phytotoxins, this characteristic could be used to develop rapid, simple and specific methods to recognize plant diseases such as the development of practical kits (i.e., rapid test strip) to be used directly in the field by farmers. Furthermore, phytotoxins could be used to select plant varieties resistant to disease instead of using whole plant-pathogen systems. In this way, the disease resistance breeding can be accelerated.

Author Contributions: Conceptualization, L.Z.; Writing—original draft preparation, D.X., L.Z., M.X., Z.S., X.J., X.H.; Writing_editing, D.X.; Writing—review, D.L. All authors have read and agreed to the published version of the manuscript.

Funding: This work was financially supported by the grants from the National Key R\&D Program of China (2017YFC1600905) and the National Natural Science Foundation of China (32072373).

Institutional Review Board Statement: Not applicable.

Informed Consent Statement: Not applicable.

Data Availability Statement: Not applicable.

Conflicts of Interest: The authors declare no conflict of interest.

\section{References}

1. Evidente, A.; Cimino, A.; Masi, M. Phytotoxins produced by pathogenic fungi of agrarian plants. Phytochem. Rev. 2019, 18, 843-870. [CrossRef]

2. Chen, H.; Singh, H.; Bhardwaj, N.; Bhardwaj, S.K.; Khatri, M.; Kim, K.-H.; Peng, W. An exploration on the toxicity mechanisms of phytotoxins and their potential utilities. Cret. Rev. Environ. Sci. Technol. 2020. [CrossRef]

3. Pontes, J.G.M.; Fernandes, L.S.; Dos Santos, R.V.; Tasic, L.; Fill, T.P. Virulence factors in the phytopathogen-host interactions: An overview. J. Agric. Food Chem. 2020, 68, 7555-7570. [CrossRef]

4. Meena, M.; Samal, S. Alternaria host-specific (HSTs) toxins: An overview of chemical characterization, target sites, regulation and their toxic effects. Toxicol. Rep. 2019, 6, 745-758. [CrossRef]

5. Walton, J.D.; Panaccione, D.G. Host-selective toxins and disease specificity: Perspectives and progress. Annu. Rev. Phytopathol. 1993, 31, 275-303. [CrossRef] [PubMed]

6. Tsuge, T.; Harimoto, Y.; Akimitsu, K.; Ohtani, K.; Kodama, M.; Akagi, Y.; Egusa, M.; Yamamoto, M.; Otani, H. Host-selective toxins produced by the plant pathogenic fungus Alternaria alternata. FEMS Microbiol. Rev. 2013, 37, 44-66. [CrossRef] [PubMed]

7. Wolpert, T.J.; Dunkle, L.D.; Ciuffetti, L.M. Hostselective toxins and avirulence determinants: What's in a name? Annu. Rev. Phytopathol. 2002, 40, 251-285. [CrossRef]

8. Strange, R.N. Phytotoxins produced by microbial plant pathogens. Nat. Prod. Rep. 2007, 24, 127-144. [CrossRef] [PubMed]

9. Strobel, G.A. Phytotoxins. Annu. Rev. Biochem. 1982, 51, 309-333. [CrossRef] [PubMed]

10. Ballio, A.; Graniti, A. Phytotoxins and their involvement in plant disease. Experientia 1991, 47, 751-864.

11. Cimmino, A.; Masi, M.; Evidente, M.; Superchi, S.; Evidente, A. Fungal phytotoxins with potential herbicidal activity: Chemical and biological characterization. Nat. Prod. Rep. 2015, 32, 1629-1653. [CrossRef] [PubMed]

12. Mobius, N.; Hertweck, C. Fungal phytotoxins as mediators of virulence. Curr. Opin. Plant Biol. 2009, 12, 390-398. [CrossRef]

13. Varejao, E.V.V.; Demuner, A.J.; Barbosa, L.C.A.; Barreto, R.W. The search for new natural herbicides-Strategic approaches for discovering fungal phytotoxins. Crop Prot. 2013, 48, 41-50. [CrossRef]

14. McLean, M. The phytotoxicity of Fusarium metabolites: An update since 1989. Mycopathologia 1996, 133, 163-179. [CrossRef] [PubMed]

15. Lou, J.; Fu, L.; Peng, Y.; Zhou, L. Metabolites from Alternaria fungi and their bioactivities. Molecules 2013, 18, 5891-5935. [CrossRef] [PubMed]

16. Kim, W.; Chen, W. Phytotoxic metabolites produced by legume-associated Ascochyta and its related genera in the Dothidemycetes. Toxins 2019, 11, 627. [CrossRef] [PubMed]

17. Chen, Y.; Kistler, H.C.; Ma, Z. Fusarium graminearum trichothecene mycotoxins: Biosynthesis, regulation and management. Annu. Rev. Phytopathol. 2019, 57, 15-39. [CrossRef]

18. Masi, M.; Cimmino, A.; Reveglia, P.; Mugnai, L.; Surico, G.; Evidente, A. Advances on fungal phytotoxins and their role in grapevine trunk diseases. J. Agric. Food Chem. 2018, 66, 5948-5958. [CrossRef] [PubMed]

19. Zhao, J.; Shan, T.; Mou, Y.; Zhou, L. Plant-derived bioactive compounds produced by endophytic fungi. Mini Rev. Med. Chem. 2011, 11, 159-168. [CrossRef] 
20. Piyasena, K.G.N.P.; Wickramarachchi, W.A.R.T.; Kumar, N.S.; Jayasinghe, L.; Fujimoto, Y. Two phytotoxic azaphilone derivatives from Chaetomium globosum, a fungal endophyte isolated from Amaranthus viridis leaves. Mycology 2015, 6, 158-160. [CrossRef]

21. Ma, K.-L.; Wei, W.-J.; Li, H.-Y.; Song, Q.-Y.; Dong, S.-H.; Gao, K. Meteroterpenoids with diverse ring systems and dioxolanone-type secondary metabolites from Phyllosticta capitalensis and their phytotoxic activity. Tetrahedron 2019, 75, 4611-4619. [CrossRef]

22. Li, S.; Shao, M.-W.; Lu, Y.-H.; Kong, L.-C.; Jiang, D.-H.; Zhang, Y.-L. Phytotoxic and antibacterial metabolites from Fusarium proliferatum ZS07 isolated from the gut of long-horned grasshoppers. J. Agric. Food Chem. 2014, 62, 8997-9001. [CrossRef] [PubMed]

23. Li, Y.-Y.; Tan, X.-M.; Wang, Y.-D.; Yang, J.; Zhang, Y.-G.; Sun, B.-D.; Gong, T.; Guo, L.-P.; Ding, G. Bioactive seco-sativene sesquiterpenoids from an Artemisia desertorum endophytic fungus, Cochliobolus sativus. J. Nat. Prod. 2020, 83, 1488-1494. [CrossRef]

24. Lu, Y.; Li, S.; Shao, M.; Xiao, X.; Kong, L.; Jiang, D.; Zhang, Y. Isolation, identification, derivatization and phytotoxic activity of secondary metabolites produced by Cladosporium oxysporum DH14, a locust-associated fungus. J. Integr. Agric. 2016, 15, 832-839. [CrossRef]

25. Mallik, M.A.B. Selective isolation and screening of soil microorganisms for metabolites with herbicidal potential. J. Crop Prot. 2001, 4, 219-236. [CrossRef]

26. Li, H.; Wei, J.; Pan, S.-Y.; Gao, J.-M.; Tian, J.-M. Antifungal, phytotoxic and toxic metabolites produced by Penicillium purpurogenum. Nat. Prod. Res. 2014, 28, 2358-2361. [CrossRef] [PubMed]

27. Huang, R.-H.; Gou, J.-Y.; Zhao, D.-L.; Wang, D.; Liu, J.; Ma, G.-Y.; Li, Y.-Q.; Zhang, C.-S. Phytotoxicity and anti-phytopathogenic activities of marine-derived fungi and their secondary metabolites. RSC Adv. 2018, 8, 37573-37580. [CrossRef]

28. Du, F.-Y.; Li, X.-M.; Sun, Z.-C.; Meng, L.-H.; Wang, B.-G. Secondary metabolites with agricultural antagonistic potentials from Beauveria felina, a marine-derived entomopathogenic fungus. J. Agric. Food Chem. 2020, 68, 14824-14831. [CrossRef]

29. Wang, J.; Zhang, R.; Chen, X.; Sun, X.; Yan, Y.; Shen, X.; Yuan, Q. Biosynthesis of aromatic polyketides in microorganisms using type II polyketide synthases. Microb. Cell Fact. 2020, 19, 110. [CrossRef]

30. Masi, M.; Aloi, F.; Nocera, P.; Cacciola, S.O.; Surico, G.; Evidente, A. Phytotoxic metabolites isolated from Neufusicoccum batangarum, the causal agent of the scabby canker of cactus pear (Opuntia ficus-indica L.). Toxins 2020, 12, 126. [CrossRef] [PubMed]

31. Meepagala, K.M.; Briscoe, W.E.; Techen, N.; Johnson, R.D.; Clausen, B.M.; Duke, S.O. Isolation of a phytotoxic isocoumarin from Diaporthe eres-infected Hedera helix (English ivy) and synthesis of its phytotoxic analogs. Pest Manag. Sci. 2018, 74, 37-45. [CrossRef]

32. Masi, M.; Santoro, E.; Clement, S.; Meyer, S.; Scafato, P.; Superchi, S.; Evidente, A. Further secondary metabolites produced by the fungus Pyricularia grisea isolated from buffelgrass (Cenchrus ciliaris). Chirality 2020, 32, 1234-1242. [CrossRef] [PubMed]

33. Hallock, Y.F.; Clardy, J.; Kenfield, D.S.; Strobel, G. De-O-methyl-diaporthin, a phytotoxin from Drechslera siccans. Phytochemistry 1988, 27, 3123-3125. [CrossRef]

34. Robeson, D.J.; Strobel, G.A. Monocerin, a phytotoxin from Exserohilum turicum (Drechslera turcica). Agric. Biol. Chem. 1982, 46, 2681-2683.

35. Parisi, A.; Piattelli, M.; Tringali, C.; Di San Lio, G.M. Indentificaton of the phytotoxin mullein in culture fluids of Phoma tracheiphila. Phytochemistry 1993, 32, 865-867. [CrossRef]

36. Cimmino, A.; Maddau, L.; Masi, M.; Linaldeddu, B.T.; Evidente, A. Secondary metabolites produced by Sardiniella urbana, a new emerging pathogen on European hackberry. Nat. Prod. Res. 2019, 33, 1862-1869. [CrossRef] [PubMed]

37. Masi, M.; Reveglia, P.; Baaijens-Billones, R.; Gorecki, M.; Pescitelli, G.; Savocchia, S.; Evidente, A. Phytotoxic metabolites from three Neofusicoccum species causal agents of Botryosphaeria dieback in Australia, luteopyroxin, neoanthraquinone, and luteoxepinone, a disubstituted furo- $\alpha$-pyrone, a hexasubstituted anthraquinone, and a trisubstituted oxepi-2-one from Neofusicoccum luteum. J. Nat. Prod. 2020, 83, 453-460.

38. Abou-Mansour, E.; Debieux, J.-L.; Ramirez-Suero, M.; Benard-Gellon, M.; Magnin-Robert, M.; Spagnolo, A.; Chong, J.; Farine, S.; Bertsch, C.; L'Haridon, F.; et al. Phytotoxic metabolites from Neofusicoccum parvum, a pathogen of Botryosphaeria dieback of grapevine. Phytochemistry 2015, 115, 207-215. [CrossRef]

39. Masi, M.; Reveglia, P.; Femina, G.; Baaijens-Bilones, R.; Savochia, S.; Evidente, A. Luteoethanones A and B two phytotoxic 1-substituted ethanones produced by Neofusicoccum luteum, a causal agent of Botryosphaeria dieback on grapevine. Nat. Prod. Res. 2020. [CrossRef]

40. Masi, M.; Meyer, S.; Clement, S.; Pescitelli, G.; Cimmino, A.; Crstofaro, M.; Evidente, A. Chloromonilinic acids C and D, phytotoxic tetrasubstituted 3-chromanonacrylic acids isolated from Cochliobolus australiensis with potential herbicidal activity against buffelgrass (Cenchrus ciliaris). J. Nat. Prod. 2017, 80, 2771-2777. [CrossRef]

41. Bashiri, S.; Abdollahzadeh, J.; Lecce, R.D.; Alioto, D.; Gorecki, M.; Pescitelli, G.; Masi, M.; Evidente, A. Rabenchromenone and rabenzophenone, phytotoxic tetrasubstituted chromenone and hexasubstituted benzophenone constituents produced by the oak-decline-associated fungus Fimetariella rabenhorstii. J. Nat. Prod. 2020, 83, 447-452. [CrossRef] [PubMed]

42. Mao, Z.; Sun, W.; Fu, L.; Luo, H.; Lai, D.; Zhou, L. Natural dibenzo- $\alpha$-pyrones and their bioactivities. Molecules 2014, 19, 5088-5108. [CrossRef]

43. Tang, J.; Huang, L.; Liu, Y.; Toshmatov, Z.; Zhang, C.; Shao, H. Two phytotoxins isolated from the pathogenic fungus of the invasive weed Xanthium italicum. Chem. Biodivers. 2020, 17, e2000043. [CrossRef] [PubMed] 
44. Demuner, A.J.; Barbosa, L.C.A.; Miranda, A.C.M.; Geraldo, G.C.; Da Silva, C.M.; Giberti, S.; Bertazzini, M.; Forlani, G. The fungal phytotoxin alternariol 9-methyl ether and some of its synthetic analogues inhibit the photosynthetic electron transport chain. $J$. Nat. Prod. 2013, 76, 2234-2245. [CrossRef] [PubMed]

45. Zhao, D.-L.; Han, X.-B.; Wang, M.; Zeng, Y.-T.; Li, Y.-Q.; Ma, G.-Y.; Liu, J.; Zheng, C.-J.; Wen, M.-X.; Zhang, Z.-F.; et al. Herbicidal and antifungal xanthone derivatives from the alga-derived fungus Aspergillus versicolor D5. J. Agric. Food Chem. 2020, 68, 11207-11214. [CrossRef] [PubMed]

46. Wu, S.-B.; Long, C.; Kennelly, E.J. Structural diversity and bioactivities of natural benzophenones. Nat. Prod. Rep. 2014, 31, 1158-1174. [CrossRef] [PubMed]

47. Hashimoto, T.; Tahara, S.; Takaoka, S.; Tori, M.; Askawa, Y. Structures of a novel binaphthyl and three novel benzophenone derivatives with plant-growth inhibitory activity from the fungus Daldinia concentrica. Chem. Pharm. Bull. 1994, 42, 1528-1530. [CrossRef]

48. Dalinova, A.; Chisty, L.; Kochura, D.; Garnyuk, V.; Petrova, M.; Prokofieva, D.; Yurchenko, A.; Dubovik, V.; Ivanov, A.; Smirnov, S.; et al. Isolation and bioactivity of secondary metabolites from solid culture of the fungus, Alternaria sonchi. Biomolecules 2020, 10, 81. [CrossRef]

49. Lu, S.; Tian, J.; Sun, W.; Meng, J.; Wang, X.; Fu, X.; Wang, A.; Lai, D.; Liu, Y.; Zhou, L. Bis-naphtho- $\gamma$-pyrones form fungi and their bioactivities. Molecules 2014, 19, 7169-7188. [CrossRef]

50. Lu, S.; Sun, W.; Meng, J.; Wang, A.; Wang, X.; Tian, J.; Fu, X.; Dai, J.; Liu, Y.; Lai, D.; et al. Bioactive bis-naphtho- $\gamma$-pyrones from rice false smut pathogen Ustilaginoidea virens. J. Agric. Food Chem. 2015, 63, 3501-3508. [CrossRef]

51. Sun, W.; Wang, A.; Xu, D.; Wang, W.; Meng, J.; Dai, J.; Liu, Y.; Lai, D.; Zhou, L. New ustilaginoidins from rice false smut balls caused by Villosiclava virens and their phytotoxic and cytotoxic activities. J. Agric. Food Chem. 2017, 65, 5151-5160. [CrossRef]

52. Gao, J.-M.; Yang, Y.-X.; Qin, J.-C. Azaphilones: Chemistry and biology. Chem. Rev. 2013, 113, 4755-4811. [CrossRef] [PubMed]

53. Nasini, G.; Arnone, A.; Assante, G.; Candiani, G.; Vajna de Pava, O. Structure and absolute configuration of acetosellin, a new polyketide from a phytotoxic strain of Cercosporella acetosella. Tetrahedron Lett. 2002, 43, 1665-1668. [CrossRef]

54. Iwai, I.; Mishima, H. Consitution of ascochitine. Chem. Ind. 1965, 73, 186-187.

55. Smith, G.R.; Munro, M.H.G.; Fineran, B.A.; Cole, A.L.J. Evidence for the involvement of asochitine in phoma leafspot-wilt disease of Clematis. Physiol. Mol. Plant Pathol. 1994, 45, 333-348. [CrossRef]

56. Nakajima, H.; Kimura, Y.; Hamasaki, T. Spiciferinone, an azaphilone phytotoxin produced by the fungus Cochliobolus spicifer. Phytochemistry 1992, 31, 105-107. [CrossRef]

57. Andolfi, A.; Cimmino, A.; Vurro, M.; Berestetskiy, A.; Troise, C.; Zonno, M.C.; Evidente, A. Agropyrenol and agropyrenal, phytotoxins from Ascochyta agropyrina var. nana, a fungal pathogen of Elitrigia repens. Phytochemsitry 2012, 79, 102-108. [CrossRef] [PubMed]

58. Supratman, U.; Hirai, N.; Sato, S.; Watanabe, K.; Malik, A.; Annas, S.; Harneti, D.; Maharani, R.; Koseki, T.; Shiono, Y. New naphthoquinone derivatives from Fusarium napiforme of a mangrove plant. Nat. Prod. Res. 2019. [CrossRef]

59. Ariefta, N.R.; Kristiana, P.; Aboshi, T.; Murayama, T.; Tawaraya, K.; Koseki, T.; Kurisawa, N.; Kimura, K.; Shiono, Y. New isocoumarins, naphthoquinones, and a cleistanthane-type from Nectria pseudotrichia 120-1NP. Fitoterapia 2018, 127, 356-361. [CrossRef]

60. Burki, N.; Michel, A.; Tabacchi, R. Naphthalenones and isocoumarins of the fungus Ceratocystis fimbriata f.sp. platani. Phytopathol. Mediterr. 2003, 42, 191-198.

61. Masi, M.; Nocera, P.; Zonno, M.C.; Tuzi, A.; Pescitelli, G.; Cimmino, A.; Boari, A.; Infantino, A.; Vurro, M.; Evidente, A. Lentiquinones A, B, and C, phytotoxic anthraquinone derivatives isolated from Ascochyta lentis, a pathogen of lentil. J. Nat. Prod. 2018, 81, 2700-2709. [CrossRef] [PubMed]

62. Ichihara, A.; Oikawa, H.; Hayashi, K.; Sakamura, S. Structures of betaenones A and B, novel phytotoxins from Phoma betae Fr. J. Am. Chem. Soc. 1983, 105, 2907-2908. [CrossRef]

63. Ichihara, A.; Oikawa, H.; Hashimoto, M.; Sakamura, S.; Haraguchi, T.; Nagano, H. A phytotoxin, betaenone C, and its related metabolites of Phoma betae Fr. Agric. Biol. Chem. 1983, 47, 2965-2967. [CrossRef]

64. Cimmino, A.; Villegas-Fernandez, A.M.; Andolfi, A.; Melck, D.; Rubiales, D.; Evidente, A. Botrytone, a new naphthalenone pentaketide produced by Botrytis fabae, the causal agent of chocolate spot disease on Vicia faba. J. Agric. Food Chem. 2011, 59, 9201-9206. [CrossRef] [PubMed]

65. Evidente, A.; Sparapano, L.; Andolfi, A.; Bruno, G. Two naphthalenone pentaketides from liquid cultures of Phaeoacremonium aleophilum, a fungus associated with esca of grapevine. Phytopathol. Mediterr. 2000, 39, 162-168.

66. Nakamura, T.; Supratman, U.; Harneti, D.; Maharani, R.; Koseki, T.; Shiono, Y. New compounds from Japanese oak wilt disease-associated fungus Raffaelea quercivora. Nat. Prod. Res. 2020. [CrossRef]

67. Tabacchi, R.; Fkyerat, A.; Poliart, C.; Dubin, G.M. Phytotoxins from fungi of esca of grapevine. Phytopathol. Mediterr. 2000, 39, 156-161.

68. Abou-Mansour, A.; Couche, E.; Tabacchi, R. Do fungal naphthalenones have a role in the development of esca symptoms? Phytopathol. Mediterr. 2004, 43, 75-82.

69. Borgschulte, K.; Rebuffat, S.; Trowitzsch-Kienast, W.; Schomburg, D.; Pinon, J.; Bodo, B. Isolation and structure elucidation of hymatoxins B-E and other phytotoxins from Hypoxylon mammatum fungal pathogen of leuce poplars. Tetrahedron 1991, 47, 8351-8360. [CrossRef] 
70. Zhou, L.; Zhao, J.; Shan, T.; Cai, X.; Peng, Y. Spirobisnaphthalenes from fungi and their biological activities. Mini Rev. Med. Chem. 2010, 10, 977-989. [CrossRef]

71. Liu, X.; Zhao, Y.; Wang, W.; Wang, M.; Zhou, L. Recent progress of natural product spirobisnaphthalenes. Chinese J. Org. Chem. 2017, 37, 2883-2894. [CrossRef]

72. Krohn, K.; Michel, A.; Florke, U.; Aust, H.-J.; Draeger, S.; Schulz, B. Palmarumycins C1-C16 form Coniothyrium sp.: Isolation, structure elucidation, and biological activity. Liebigs Ann. Chem. 1994, 11, 1099-1108. [CrossRef]

73. Macias-Rubalcava, M.; Sobrino, M.E.R.-V.; Melendez-Gonzalez, C.; Hernandez-Ortega, S. Naphthoquinone spiroketals and organic extracts from the endophytic fungus Ednia gomezpompae as potential herbicides. J. Agric. Food Chem. 2014, 62, 3553-3562. [CrossRef] [PubMed]

74. Masi, M.; Evidente, A. Fungal bioactive anthraquinones and analogues. Toxins 2020, 12, 714. [CrossRef]

75. Evidente, A.; Rodeva, R.; Andolfi, A.; Stoyanova, Z.; Perrone, C.; Motta, A. Phytotoxic polyketides produced by Phomopsis foeniculi, a strain isolated from diseased Bulgarian fennel. Eur. J. Plant Pathol. 2011, 130, 173-182. [CrossRef]

76. Suemitsu, R.; Yamada, Y.; Sano, T.; Yamashita, K. Phytotoxic activities of altersolanol A, B and dactylariol, and activities of altersolanol A against some microorganism. Agric. Biol. Chem. 1984, 48, 2383-2384.

77. Charudattan, R.; Rao, K.V. Bostrycin and 4-deoxybostrycin: Two nonspecific phytotoxins produced by Alternaria eichhorniae. Appl. Environ. Microbiol. 1982, 43, 846-849. [CrossRef] [PubMed]

78. Babu, R.M.; Saeena, A.; Seetharaman, K.; Ebenezar, E.G.; Raja, A.S.; Biji, K.R.; Prakash, M.S. Isolation and characterisation of phytotoxic substance from Alternaria alternata-A leaf blight pathogen on Eichhornia crassipes. J. Ecobiol. 2003, 15, 315-318.

79. Bouras, N.; Strelkov, S.E. The anthraquinone catenarin is phytotoxic and produced in leaves and kernels of wheat infected by Pyrenophora tritici-repentis. Physiol. Mol. Plant Pathol. 2008, 72, 87-95. [CrossRef]

80. Assante, G.; Nasini, G. Identity of the phytotoxin stemphylin from Stemphylium botryosum with altersolanol A. Phytochemistry 1987, 26, 703-705. [CrossRef]

81. Tanaka, M.; Ohra, J.; Tsujino, Y.; Fujimori, T.; Ago, H.; Tsuge, H. Dendryol A, B, C, and D, four new compounds produced by a weed pathogenic fungus Dendryphiella sp. Z. Naturfursch. C 1995, 50, 751-756. [CrossRef]

82. Gallagher, R.; Hodeges, R. The chemistry of dothistromin a difuronanthraquinone from Dothistroma pini. Aust. J. Chem. 1972, 25, 2399-2407. [CrossRef]

83. Schor, R.; Cox, R. Classic fungal natural products in the genomic age: The molecular legacy of Harold Raistrick. Nat. Prod. Rep. 2018, 35, 230-256. [CrossRef]

84. Dong, X.; Fu, J.; Yin, X.; Cao, S.; Li, X.; Lin, L.; Qi, H.; Ni, J. Emodin: A review of its pharmacology, toxicity and pharmacokinetics. Phytother. Res. 2016, 30, 1207-1218. [CrossRef] [PubMed]

85. Izhaki, I. Emodin: A secondary metabolite with multiple ecological functions in higher plants. New Phytol. 2002, 155, 205-217. [CrossRef]

86. Macias, M.; Ulloa, M.; Gamboa, A.; Mata, R. Phytotoxic compounds from the new coprophilous fungus Guanomyces polythrix. J. Nat. Prod. 2000, 63, 757-761. [CrossRef]

87. Andolfi, A.; Cimmino, A.; Villegas-Fernadez, A.M.; Tuzi, A.; Santini, A.; Melck, D.; Rubiales, D.; Evidente, A. Lentisone, a new phytotoxic anthraquinone produced by Aschyta lentis, the causal agent of Ascochyta blight in Lens culinaris. J. Agric. Food Chem. 2013, 61, 7301-7308. [CrossRef]

88. Nakajima, S. Metabolites of phytotoxic fungi. I. Isolation of macrosporin and 6-methylxanthopurpurin 3-methyl ether from Alternaria bataticola. Chem. Pharm. Bull. 1973, 21, 2083-2085. [CrossRef]

89. Tanaka, M.; Fukushima, T.; Tsujino, Y.; Fujimori, T. Nigrosporins A and B, new phytotoxic and antibacterial metabolites produced by a fungus Nigrospora oryzae. Biosci. Biotechnol. Biochem. 1997, 61, 1848-1852. [CrossRef]

90. Quereshi, S.; Khan, N.A.; Pandey, A.K. Anthraquinone pigment with herbicidal potential from Phoma herbarum FGCC\# 54. Chem. Nat. Compd. 2011, 47, 521-523.

91. Gui, R.-Y.; Xu, L.; Kuang, Y.; Chung, I.-M.; Qin, J.-C.; Liu, L.; Yang, S.-X.; Zhao, L.-C. Chaetominine, (+)-alantrypinone, questin, isorhodoptilometrin, and 4-hydroxybenzaldehyde produced by the endophytic fungus Aspergillus sp. YL-6 inhibit wheat (Triticum aestivum) and radish (Raphanus sativus) germination. J. Plant Interact. 2015, 10, 87-92.

92. Daub, M.E.; Herrero, S.; Chung, K.-R. Photoactivated perylenequinone toxins in fungal pathogenesis of plants. FEMS Microbiol. Lett. 2005, 252, 197-206. [CrossRef]

93. Stierle, A.C.; Cardellina II, J.H.; Strobel, G.A. Phytotoxins from Alternaria alternata, a pathogen of spotted knapweed. J. Nat. Prod. 1989, 52, 42-47. [CrossRef]

94. Hradil, C.M.; Hallock, Y.F.; Clardy, J.; Kenfield, D.S.; Strobel, G. Phytotoxins from Alternaria cassiae. Phytochemistry 1989, 28 , 73-75. [CrossRef]

95. Bruns, R.F.; Miller, F.D.; Merriman, R.L.; Howbert, J.J.; Heath, W.F.; Kobayashi, E.; Takahashi, I.; Tamaoki, T.; Nakano, H. Inhibition of protein kinase C by calphostin C is light-dependent. Biochem. Biophys. Res. Commun. 1991, 176, 288-293. [CrossRef]

96. Daub, M.E. Cercosporin, a photosensitizing toxin from Cercospora pecies. Phytopathology 1982, 72, 370-374. [CrossRef]

97. Daub, M.E.; Ehrenshaft, M. The photoactivated Cercospora toxin cercosporin: Contributions to plant disease and fundamental biology. Annu. Rev. Phytopathol. 2000, 38, 461-490. [CrossRef]

98. Tabuchi, H.; Tajimi, A.; Ichihara, A. Phytotoxic metabolites isolated from Scolecotrichum graminis Fuckel. Biosci. Biotechnol. Biochem. 1994, 58, 1956-1959. [CrossRef] 
99. Boss, D.; Maurhofer, M.; Schlapfer, E.; Defago, G. Elsinochrome A production by the bindweed biocontrol fungus Stagonospora convolvuli LA39 does not pose a risk to the environmentor the consumerof treated crops. FEMS Microbiol. Ecol. 2007, 59, 194-205. [CrossRef] [PubMed]

100. Meepagala, K.M.; Johnson, R.D.; Robert, D.; Duke, S.O. Curvularin and dehydrocurvularin as phytotoxic constituents from Curvularia intermedia infecting Pandanus amaryllifolius. J. Agric. Chem. Environ. 2016, 5, 12-22.

101. Vurro, M.; Evidente, A.; Andolfi, A.; Zonno, M.C.; Giordano, F.; Motta, A. Brefeldin A and $\alpha, \beta$-dehydrocurvularin, two phytotoxins from Alternaria zinniae, a biocontrol agent of Xanthium occidentale. Plant Sci. 1998, 138, 67-79. [CrossRef]

102. Gutierrez, M.; Thoduloz, C.; Rodriguez, J.; Lolas, M.; Schmeda-Hirschmann, G. Bioactive metabolites from the fungus Nectria galligena, the main apple canker agent in Chile. J. Agric. Food Chem. 2005, 53, 7701-7708. [CrossRef]

103. Veiga, T.A.M.; Silva, S.C.; Francisco, A.-C.; Filho, E.R.; Vieira, P.C.; Fernandes, J.B.; Silva, M.F.G.F.; Muller, M.W.; Lotina-Hennen, B. Inhibition of photophosphorylation and electron transport chain in thyakoids by lasiodiplodin, a natural product from Botryosphaeria rhodina. J. Agric. Food Chem. 2007, 55, 4217-4221. [CrossRef] [PubMed]

104. Sato, S.; Sofian, F.F.; Suehiro, W.; Harneti, D.; Maharani, R.; Supratman, U.; Abdullah, F.F.A.; Koseki, T.; Shiono, Y. $\beta$-Resorcylic acid derivatives, with their phytotoxic activities, from the endophytic fungus Lasiodiplodia theobromae in the mangrove plant Xylocarpus granatum. Chem. Biodivers. 2021, 18, e2000928. [CrossRef] [PubMed]

105. Oyama, H.; Sassa, T.; Ikeda, M. Structures of new plant growth inhibitors, trans- and cis-resorcylide. Agric. Biol. Chem. 1978, 42, 2407-2409. [CrossRef]

106. Ramezani, M.; Shier, W.T.; Abbas, H.K.; Tonos, J.L.; Baird, R.E.; Sciumbato, G.L. Soybean charcoal rot disease fungus Macrophomina phaseolina in Mississippi produces the phytotoxin (-)-botryodiplodin but no detectable phaseolinone. J. Nat. Prod. 2007, 70, 128-129. [CrossRef]

107. Nouguier, R.; Gastaldi, S.; Stien, D.; Bertrand, M.; Villar, F.; Andrey, O.; Renaud, P. Synthesis of ( \pm )- and (-)-botryodiplodin using stereoselective radical cyclizations of acysclic esters and acetals. Tetrahedron Asymmetry 2003, 14, 3005-3018. [CrossRef]

108. Di Lecce, R.; Bashiri, S.; Masi, M.; Alioto, D.; Tuzi, A.; Abdollahzadeh, J.; Evidente, A. Phytotoxic metabolites from Stilbocrea macrostoma, a fungal pathogen of Quercus brantii in Iran. Nat. Prod. Res. 2020. [CrossRef]

109. Tchoukoua, A.; Ota, T.; Akanuma, R.; Ju, Y.-M.; Supratman, U.; Murayama, T.; Koseki, T.; Shiono, Y. A phytotoxic bicyclic lctones and other compounds from endophyte Xylaria curta. Nat. Prod. Res. 2017, 31, 2113-2118. [CrossRef]

110. Evidente, A.; Berestetskiy, A.; Cimmino, A.; Tuzi, A.; Superchi, S.; Melck, D.; Andolfi, A. Papyracillic acid, a phytotoxic 1,6dioxaspiro[4,4]nonene produced by Ascochyta agropyrina var. nana, a potential mycoherbicide for Elytrigia repens biocontrol. J. Agric. Food Chem. 2009, 57, 11168-11173. [CrossRef]

111. Martinez-Luis, S.; Gonalez, M.C.; Ulloa, M.; Mata, R. Phytotoxins from the fungus Malbranchea aurantiaca. Phytochemistry 2005, 66, 1012-1016. [CrossRef]

112. Evidente, A.; Sparapano, L.; Fierro, O.; Bruno, G.; Motta, A. Sapinofuranones A and B, two new 2(3H)-dihydrofuranones produced by Sphaeropsis sapinea, a common pathogen of conifers. J. Nat. Prod. 1999, 62, 253-256. [CrossRef] [PubMed]

113. Sparapano, L.; Evidente, A. Studies on structure-activity relationship of seiridins, phytotoxins produced by three species of Seiridium. Nat. Toxins 1995, 3, 166-173. [CrossRef]

114. Evidente, A.; Sparapano, L. $7^{\prime}$-Hydroxyseiridin and $7^{\prime}$-hydroxyisoseiridin two new phytotoxic $\Delta \alpha, \beta$-butanolides from three species of Seiridium pathogenic to cypresses. J. Nat. Prod. 1994, 57, 1720-1725. [CrossRef]

115. Nukina, M. Terrestric acid as a phytotoxic metabolite from Pyricularia oryzae Cavara. Agric. Biol. Chem. 1988, 52, 2357-2358. [CrossRef]

116. Supratman, U.; Suzuki, T.; Nakamura, T.; Yokoyama, Y.; Harneti, D.; Maharani, R.; Salam, S.; Abdullah, F.F.; Koseki, T.; Shiono, Y. New metabolites produced by endophytic Clonostachys rosea B5-2. Nat. Prod. Res. 2019. [CrossRef] [PubMed]

117. Abate, D.; Abraham, W.-R.; Meyer, H. Cytochalasins and phytotoxins from the fungus Xylaria obovata. Phytochemistry 1997, 44, 1443-1448. [CrossRef]

118. Gardner, J.M.; Kono, Y.; Tatum, J.H.; Suzuki, Y.; Takeuchi, S. Plant pathotoxins from Alternaria citri: The major toxin specific for rough lemon plants. Phytochemistry 1985, 24, 2861-2867. [CrossRef]

119. Kono, Y.; Gardner, J.M.; Suzuki, Y.; Takeuchi, S. Plant pathotoxins from Alternaria citri: The minor ACRL toxins. Phytochemistry 1985, 24, 2869-2874. [CrossRef]

120. Maiero, M.; Bean, G.A.; Ng, T.J. Toxin production by Alternaria solani and its related phytotoxicity to tomato breeding lines. Phytopathology 1991, 81, 1030-1033. [CrossRef]

121. Gohbara, M.; Hyeon, S.B.; Suzuki, A.; Tamura, S. Isolation and structure elucidation of colletopyrone from Colletotrichum nicotianae. Agric. Biol. Chem. 1976, 40, 1453-1455. [CrossRef]

122. Evidente, A.; Maddau, L.; Spanu, E.; Franceschini, A.; Lazzaroni, S.; Motta, A. Diplopyrone, a new phytotoxic tetrahydropyranpyran2-one produced by Diplodia mutila, a fungus pathogen of cork oak. J. Nat. Prod. 2003, 66, 313-315. [CrossRef]

123. Masi, M.; Maddau, L.; Linaldeddu, B.T.; Cimmino, A.; D'Amico, W.; Scanu, B.; Evidente, M.; Tuzi, A.; Evidente, A. Bioactive secondary metabolites produced by the oak pathogen Diplodia corticola. J. Agric. Food Chem. 2016, 64, 217-225. [CrossRef] [PubMed]

124. Fuse, M.; Mazzeo, G.; Longhi, G.; Abbate, S.; Masi, M.; Evident, A.; Puzarini, C.; Barone, V. Unviased determination of absolute configurations by vis-à-vis comparison of experimental and simulated spectra: The challenging case of diplopyrone. J. Phys. Chem. B 2019, 123, 9230-9237. [CrossRef] [PubMed] 
125. Andolfi, A.; Boari, A.; Evidente, M.; Cimmino, A.; Vurro, M.; Ash, G.; Evidente, A. Gulypyrones A and B and phomentrioloxins B and C produced by Diaporthe gulyae, a potential mycoherbicide for saffron thistle (Carthamus lanatus). J. Nat. Prod. 2015, 78, 623-629. [CrossRef]

126. Evidente, A.; Zonno, M.C.; Andolfi, A.; Troise, C.; Cimmino, A.; Vurro, M. Phytotoxic $\alpha$-pyrones produced by Pestalotiopsis guepinii, the causal agent of hazelnut twig blight. J. Antibiot. 2012, 65, 203-206. [CrossRef]

127. Turkkan, M.; Andolfi, A.; Zonno, M.C.; Erper, I.; Perrone, C.; Cimmino, A.; Vurro, M.; Evidente, A. Phytotoxins produced by Pestalotiopsis guepinii, the causal agent of hazelnut twig blight. Phytopathol. Mediterr. 2011, 50, 154-158.

128. Tringali, C.; Parisi, A.; Piattelli, M.; Di San Lio, G.M. Phomenins A and B, bioactive polypropinoate pyrones from culture fluids of Phoma tracheiphila. Nat. Prod. Lett. 1993, 3, 101-106. [CrossRef]

129. Solfrizzo, M.; Vitti, C.; De Girolamo, A.; Visconti, A.; Logrieco, A.; Fanizzi, F.P. Radicinols and radicinin phytotoxins produced by Alternaria radicina on carrots. J. Agric. Food Chem. 2004, 52, 3655-3660. [CrossRef]

130. Masi, M.; Meyer, S.; Clement, S.; Cimmino, A.; Cristofaro, M.; Evidente, A. Cochliotoxin, a dihydropyranopyran-4,5-dione, and its analogues produced by Cochliobolus australiensis display phytotoxic activity against buffelgrass (Cenchrus ciliaris). J. Nat. Prod. 2017, 80, 1241-1247. [CrossRef]

131. Zhang, Y.; Kong, L.; Jiang, D.; Yin, C.; Cai, Q.; Chen, Q.; Zheng, J. Phytotoxic and antifungal metabolites from Curvularia sp. FH01 isolated from the gut of Atractomorpha sinensis. Bioresource Technol. 2011, 102, 3575-3577. [CrossRef] [PubMed]

132. Ichihara, A.; Tazaki, H.; Sakamura, S. Solanapyrones A, B and C, phytotoxic etabolites from the fungus Alternaria solani. Tetrahedron Lett. 1983, 24, 5373-5376. [CrossRef]

133. Alam, S.S.; Bilton, J.N.; Slawin, M.Z.; Williams, D.J.; Sheppard, R.N.; Strange, R.N. Chickpea blight: Production of the phytotoxins solanapyrones A and C by Asochyta rabiei. Phytochemistry 1989, 28, 2627-2630. [CrossRef]

134. Nakajima, H.; Hamasaki, T.; Kohno, M.; Kimura, Y. Spiciferones B and C, minor phytotoxins from the fungus Cochliobolus spicifer. Phytochemistry 1991, 30, 2563-2565. [CrossRef]

135. Nakajima, H.; Fujimoto, H.; Kimura, Y.; Hamasaki, T. Importance of the ketone function for the phytotoxicity of spiciferone A, a phytotoxin produced by the fungus Cochliobolus spicifer. Biosci. Biotechnol. Biochem. 1993, 57, 1938-1939. [CrossRef]

136. Evidente, A.; Masi, M.; Linaldeddu, B.T.; Franceschini, A.; Scanu, B.; Cimmino, A.; Andolfi, A.; Motta, A.; Maddau, L. Afritoxinones A and B, dihydrofuropyran-2-ones produced by Diplodia africana the causal agent of branch dieback on Juniperus phoenicea. Phytochemistry 2012, 77, 245-250. [CrossRef]

137. Evidente, A.; Andolfi, A.; Madau, L.; Franceschini, A.; Marras, F. Biscopyran, a phytotoxic hexasubstituted pyranopyran produced by Biscogniauxia mediterranea, a fungus pathogen of cork oak. J. Nat. Prod. 2005, 68, 568-571. [CrossRef] [PubMed]

138. Evidente, M.; Cimmino, A.; Zonno, M.C.; Masi, M.; Berestetskyi, A.; Santoro, E.; Superchi, S.; Vurro, M.; Evidente, A. Phytotoxins produced by Phoma chenopodiicola, a fungal pathogen of Chenopodium album. Phytochemistry 2015, 117, 482-488. [CrossRef] [PubMed]

139. Hirota, A.; Sakai, H.; Isogai, A. New plant growth regulators, cladospolide A and B, macrolides produced by Cladosporium cladosporioides. Agric. Biol. Chem. 1985, 49, 731-735. [CrossRef]

140. Fujii, Y.; Fukuda, A.; Hamasaki, T.; Ichimoto, I.; Hiromitsu, N. Twelve-membered lactones produced by Cladosporium tenuissimum and the plant growth retardant activity of cladospolide B. Phytochemistry 1995, 40, 1443-1446. [CrossRef]

141. Yuan, C.; Ding, G.; Wang, H.; Guo, Y.; Ma, X.; Zou, Z. Phytotoxic secondary metabolites from the endolichenic fungus Myxotrichum sp. Chem. Nat. Compt. 2018, 54, 638-641. [CrossRef]

142. Rivero-Cruz, J.F.; Garcia-Aguirre, G.; Cerda-Garcia-Rojas, C.M.; Mata, R. Conformational behavior and absolute stereostructure of two phytotoxic nonenolides from the fungus Phoma herbarum. Tetrahedron 2000, 56, 5337-5344. [CrossRef]

143. Rivero-Cruz, J.F.; Macias, M.; Cerda-Garcia-Rojas, C.M.; Mata, R. A new phytotoxic nonenolide from Phoma herbarum. J. Nat. Prod. 2003, 66, 511-514. [CrossRef]

144. Cimmino, A.; Andolfi, A.; Fondevilla, S.; Abouzeid, M.A.; Rubiales, D.; Evidente, A. Pinolide, a new noneolide produced by Didymella pinodes, the causal agent of Ascochyta blight on Pisum sativum. J. Agric. Food Chem. 2012, 60, 5273-5278. [CrossRef]

145. Yang, Z.; Ge, M.; Yin, Y.; Chen, Y.; Luo, M.; Chen, D. A novel phytotoxic nonenolide from Phomopsis sp. HCCB03520. Chem. Biodivers. 2012, 9, 403-408. [CrossRef] [PubMed]

146. Evidente, A.; Lanzetta, R.; Capasso, R.; Vurro, M.; Bottalico, A. Pinlidoxin, a phytotoxic nonenolide from Ascochyta pinodes. Phytochemistry 1993, 34, 999-1003. [CrossRef]

147. Evidente, A.; Capasso, R.; Abouzeid, M.A. Three new toxic pinolidoxins from Ascochyta pinodes. J. Nat. Prod. 1993, 56, 1937-1943. [CrossRef]

148. Evidente, A.; Lanzetta, R.; Capasso, R.; Andolfi, A.; Bottalico, A.; Vurro, M.; Zonno, M.C. Putaminoxin, a phytotoxic nonenolide from Phoma putaminum. Phytochemistry 1995, 40, 1637-1641. [CrossRef]

149. Evidente, A.; Lanzetta, R.; Capasso, R.; Andolfi, A.; Vurro, M.; Zonno, M.C. Putaminoxins B and C from Phoma putaminum. Phytochemistry 1997, 44, 1041-1045. [CrossRef]

150. Lerario, P.; Graniti, A. Phytotoxic activity of pyrenophorin and its production in cultures of Pyrenophora avenae Ito et Kurib. Phytoathol. Mediterr. 1985, 24, 280-283.

151. Sugawara, F.; Strobel, G.A. (-)-Dihydropyrenophorin, a novel and selective phytotoxin produced by Drechslera avenae. Plant Sci. 1986, 43, 1-5. [CrossRef] 
152. Kastanias, M.A.; Chrysayi-Tokousbalides, M. Herbicidal potential of pyrenophorol isolated from a Drechslera avenae pathotype. Pest Manag. Sci. 2000, 56, 227-232. [CrossRef]

153. Ballio, A.; Evidente, A.; Graniti, A.; Randazzo, G.; Sparapano, L. Phytotoxins produced by species of Seiridium causing canker diseases of cypress. Part 3. Seiricuprolide, a new phytotoxic macrolide from a strain of Seiridium cupressi infecting cypress. Phytochemistry 1988, 27, 3117-3121. [CrossRef]

154. Harned, A.M.; Volp, K.A. The sorbicillinoid family of natural products: Isolation, biosynthesis and synthetic studies. Nat. Prod. Rep. 2011, 28, 1790-1810. [CrossRef] [PubMed]

155. Meng, J.; Wang, X.; Xu, D.; Fu, X.; Zhang, X.; Lai, D.; Zhou, L.; Zhang, G. Sorbicillinoids from fungi and their bioactivities. Molecules 2016, 21, 715. [CrossRef] [PubMed]

156. Meng, J.; Gu, G.; Dang, P.; Zhang, X.; Wang, W.; Dai, J.; Liu, Y.; Lai, D.; Zhou, L. Sorbicilinoids from the fungus Ustiaginoidea virens and their phytotoxic, cytotoxic, and antimicrobial activities. Front. Chem. 2019, 7, 435. [CrossRef] [PubMed]

157. Maekawa, N.; Yamamoto, M.; Nishimura, S.; Kohmoto, K.; Kuwada, K.; Watanabe, Y. Studies on host-specific AF-toxins produced by Alternaria alternata strawberry pathotype causing Alternaria black spot of strawberry. (1) Production of hostspecific toxins and their biological activities. Ann. Phytopathol. Soc. Jpn. 1984, 50, 600-609. [CrossRef]

158. Tanaka, M.; Ohra, J.; Tsujino, Y.; Sawaji, Y.; Fujimori, T. Phytotoxin produced by Nimbya scirpicola. Biosci. Biotechnol. Biochem. 1994, 58, 565-566. [CrossRef]

159. Shukla, R.S.; Agrawal, P.K.; Husain, A. Drechslerol A, a new phytotoxic metabolite produced by Drechslera maydis, a strain from Costus speciosus. Plant Sci. 1987, 48, 159-163. [CrossRef]

160. Shukla, R.S.; Agrawal, P.K.; Thakur, R.S.; Husain, A. Drechslerol B, a host-selective phytotoxin produced by Drechslera maydis. Phytochemistry 1989, 28, 2089-2091. [CrossRef]

161. Shukla, R.S.; Agrawal, P.K.; Thakur, R.S.; Husain, A. Drechslerol C, a phytotoxin produced by Drechslera maydis, the causal organism of leaf blight of Costus speciosus. Plant Sci. 1990, 66, 43-49. [CrossRef]

162. Danko, S.J.; Kono, Y.; Daly, J.M.; Suzuki, Y.; Takeuchi, S.; McCrery, D.A. Structure and biological activity of a host-specific toxin produced by the fungal corn pathogen Phyllosticta maydis. Biochemistry 1984, 23, 759-766. [CrossRef]

163. Reveglia, P.; Savocchia, S.; Billones-Baaijens, R.; Masi, M.; Evidente, A. Spencertoxin and spencer acid, new phytotoxic derivatives of diacrylic acid and dipyridinbutan-1,4-diol produced by Spencermartinsia viticola, a causal agent of grapevine Botryosphaeria dieback in Australia. Arab. J. Chem. 2020, 13, 1803-1808. [CrossRef]

164. Jacob, S.; Groetsch, T.; Foster, A.J.; Schueffler, A.; Rieger, P.H.; Sandjo, L.P.; Lirmann, J.C.; Opatz, T.; Thines, E. Unravelling the biosynthesis of pyriculol in the rice blast fungus Magnaporthe oryzae. Microbiology 2017, 163, 541-553. [CrossRef] [PubMed]

165. Mafezoli, J.; Xu, Y.; Hilario, F.; Fredhof, B.; Espinosa-Artiles, P.; Dos Santos, L.C.; De Oliveira, M.C.F.; Gunatilaka, A.A.L. Modulation of polyketide biosynthetic pathway of the endophytic fungus Anteaglonium sp. FL0768, by copper (II) and anacardic acid. Phytochem. Lett. 2018, 28, 157-163. [CrossRef]

166. Evidente, A.; Capasso, R.; Vurro, M.; Bottalico, A. Ascosalitoxin, a phytotoxic trisubstituted salicylic aldehyde from Ascochyta pisi. Phytochemistry 1993, 34, 995-998. [CrossRef]

167. Pedras, M.S.C.; Yu, Y. Phytotoxins, elicitors and other secondary metabolites from phytopathogenic "blackleg" fungi: Structure, phytotoxicity and biosynthesis. Nat. Prod. Commun. 2009, 4, 1291-1304. [CrossRef] [PubMed]

168. Reveglia, P.; Savocchia, S.; Billones-Baaijens, R.; Cimmino, A.; Evidente, A. Isolation of phytotoxic phenols and characterization of a new 5-hydroxymethyl-2-isopropoxyphenol from Dothiorella vidmadera, a causal agent of grapevine trunk disease. J. Agric. Food Chem. 2018, 66, 1760-1764. [CrossRef]

169. Leyte-Lugo, M.; Richomme, P.; Poupard, P.; Pena-Rodriguez, L.M. Identification and quantification of a phytotoxic metabolite from Alternaria dauci. Molecules 2020, 25, 4003. [CrossRef] [PubMed]

170. Kono, Y.; Sekido, S.; Yamaguchi, I.; Kondo, H.; Suzuki, Y.; Neto, G.C.; Sakurai, A.; Yaegashi, H. Structures of two novel pyriculolrelated compounds and identification of naturally produced epipyriculol from Pyricularia oryzae. Agric. Biol. Chem. 1991, 55, 2785-2791. [CrossRef]

171. Evidente, A.; Randazzo, G.; Iacobellis, N.S.; Bottalico, A. Structure of cavoxin, a new phytotoxin from Phoma cava and cavoxone, its related chroman-4-one. J. Nat. Prod. 1985, 48, 916-923. [CrossRef]

172. Masi, M.; Cimmino, A.; Boari, A.; Tuzi, A.; Zonno, M.C.; Baroncelli, R.; Vurro, M.; Evidente, A. Colletochlorins E and F, new phytotoxic tetrasubstituted pyran-2-one and dihydrobenzofuran, isolated from Colletotrichum higginsianum with potential herbicidal activity. J. Agric. Food Chem. 2017, 65, 1124-1130. [CrossRef]

173. Cimmino, A.; Nocera, P.; Linaldeddu, B.T.; Masi, M.; Gorecki, M.; Pescitelli, G.; Montecchio, L.; Maddau, L.; Evidente, A. Phytotoxic metabolites produced by Diaporthella cryptica, the causal agent of hazelnut branch canker. J. Agric. Food Chem. 2018, 66, 3435-3442. [CrossRef] [PubMed]

174. Kenfield, D.; Hallock, Y.; Clardy, J.; Strobel, G. Curvulin and O-methylcurvulinic acid: Phytotoxic metabolites of Drechslera indica which cause necroses on purslane and spiny amaranth. Plant Sci. 1989, 60, 123-127. [CrossRef]

175. Cimmino, A.; Maddau, L.; Masi, M.; Evidente, M.; Linaldeddu, B.T.; Evidente, A. Further secondary metabolites produced by Diplodia corticola, a fungal pathogen involved in cork oak decline. Tetrahedron 2016, 72, 6788-6793. [CrossRef]

176. Song, Q.-Y.; Nan, Z.-B.; Gao, K.; Song, H.; Tian, P.; Zhang, X.-X.; Li, C.-J.; Xu, W.-B.; Li, X.-Z. Antifungal, phytotoxic, and cytotoxic activities of metabolites from Epichloë bromicola, a fungus obtained from Elymus tangutorum grass. J. Agric. Food Chem. 2015, 63, 8787-8792. [CrossRef] [PubMed] 
177. Ichihara, A.; Sawamura, S.; Kawakami, Y.; Sakamura, S. Dihydrogladiolic acid, another phytotoxin from Phoma asparagi Sacc. Agric. Biol. Chem. 1985, 49, 1891-1892.

178. Masi, M.; Nocera, P.; Boari, A.; Cimmino, A.; Zonno, M.C.; Infantino, A.; Vurro, M.; Evidente, A. Lathyroxins A and B, phytotoxic monosubstituted phenols isolated from Ascochyta lentis var. lathyri, a fungal pathogen of grass pea (Lathyrus sativus). J. Nat. Prod. 2018, 81, 1093-1097. [CrossRef] [PubMed]

179. Mazars, C.; Rossignol, M.; Auriol, P.; Klaebe, A. Phomozin, a phytotoxin from Phomopsis helianthi, the causal agent of stem canker of sunflower. Phytochemistry 1990, 29, 3441-3444. [CrossRef]

180. Iwasaki, S.; Muro, H.; Sasaki, K.; Nozoe, S.; Okuda, S.; Sato, Z. Isolations of phytotoxic substances produced by Pyricularia oryzae Cavara. Tetrahedron Lett. 1973, 14, 3537-3542. [CrossRef]

181. Tanaka, K.; Nakamura, Y.; Sasaki, A.; Ueda, R.; Suzuki, Y.; Kuwahara, S.; Kiyota, H. Synthesis and plant growth inhibitory activity of both enantiomers of pyricuol, a phytotoxin isolated from rive blast disease fungus Magnaporthe grisea. Tetrahedron 2009, 65, 6115-6122. [CrossRef]

182. Kim, J.-C.; Min, J.-Y.; Kim, H.-T.; Cho, K.-Y.; Yu, S.-H. Pyricuol, a new phytotoxin from Magnaporthe grisea. Biosci. Biotechnol. Biochem. 1998, 62, 173-174. [CrossRef] [PubMed]

183. Motoyama, T. Secondary metabolites of the rice blast fungus Pyricularia oryzae: Biosynthesis and biological function. Int. J. Mol. Sci. 2020, 21, 8691. [CrossRef]

184. Solfrizzo, M.; Strange, R.N.; Sabia, C.; Visconti, A. Production of a toxin stemphol by Stemphylium species. Nat. Toxins 1994, 2, 14-18. [CrossRef] [PubMed]

185. Stierle, A.; Hershenhorn, J.; Strobel, G. Zinniol-related phytotoxins from Alternaria cichorii. Phytochemistry 1993, 32, 1145-1149. [CrossRef]

186. Ulloa-Benitez, A.; Medina-Romero, Y.M.; Sanchez-Fernandez, R.E.; Lappe-Oliveras, P.; Roque-Flores, G.; Duarte Lisci, G.; Herrera Suarez, T.; Macias-Rubalcava, M.L. Phytotoxic and antimicrobial activity of volatile and semi-volatile organic compounds from the endophyte Hypoxylon anthochroum strain Blaci isolated from Bursera lancifolia (Burseraceae). J. Appl. Microbiol. 2016, 121, 380-400. [CrossRef]

187. Ichihara, A.; Sawamura, S.; Sakamura, S. Structures of altiloxins A and B, phytotoxins from Phoma asparagi Sacc. Tetrahedron Lett. 1984, 25, 3209-3212. [CrossRef]

188. Shimada, A.; Kusano, M.; Takeuchi, S.; Fujioka, S.; Inokuchi, T.; Kimura, Y. Asterric acid and 6-hydroxymellein, inhibitors of pollen development in Arabidopsis thaliana, produced by Aspergillus terreus. Z. Naturforsch. C 2002, 57, 459-464. [CrossRef] [PubMed]

189. Yan, Y.; Liu, Q.; Zhang, X.; Yuan, S.; Bat-Erdene, U.; Nguyen, C.; Gan, J.; Zhou, J.; Jacobsen, S.E.; Tang, Y. Resistance-gene-directed discovery of a natural-product herbicide with a new mode of action. Nature 2018, 559, 415-418. [CrossRef] [PubMed]

190. Sugawara, F.; Strobel, G.; Fisher, L.E.; Van Duyne, G.D.; Clardy, J. Bipolaroxin, a selective phytotoxin produced by Bipolaris cynodontis. Proc. Natl. Acad. Sci. USA 1985, 82, 8291-8294. [CrossRef]

191. Jahani, M.; Aggarwal, R.; Gupta, S.; Sharma, S.; Dureja, P. Purification and characterization of a novel toxin from Bipolaris sorokiniana, causing spot blotch of wheat and analysis of variability in the pathogen. Cereal Res. Commun. 2014, 42, 252-261. [CrossRef]

192. Duran-Patron, R.; Hernandez-Galan, R.; Rebordinos, L.G.; Cantoral, J.M.; Collado, I.G. Structure-activity relationships of new phytotoxic metabolites with the botryane skeleton from Botrytis cinerea. Tetrahedron 1999, 55, 2389-2400. [CrossRef]

193. D’Ambrosio, J.M.; Gonorazky, G.; Sueldo, D.J.; Moraga, J.; Di Palma, A.A.; Lamattina, L.; Collado, I.G.; Laxalt, A.M. The sesquiterpene botrydial from Botrytis cinerea induces phosphatidic acid production in tomato cell suspensions. Planta 2018, 247, 1001-1009. [CrossRef] [PubMed]

194. Zhang, L.; Wang, S.-Q.; Li, X.-J.; Zhang, A.-L.; Zhang, Q.; Gao, J.-M. New insight into the stereochemistry of botryosphaeridione from a Phoma endophyte. J. Mol. Struct. 2012, 1016, 72-75. [CrossRef]

195. Qader, M.M.; Kumar, N.S.; Jayasinghe, L.; Araya, H.; Fujimoto, Y. Bioactive sesquiterpenes from an endophytic fungus Bipolaris sorokiniana isolated from a popular medicinal plant Costus speciosus. Mycology 2017, 8, 17-20. [CrossRef]

196. Taniguchi, E.; White, G.A. The mode of action of helminthosporal. II. Effect on the permeability of plant cell membrane. Can. J. Bot. 1972, 50, 1415-1420.

197. Shiono, Y.; Matsuzaka, R.; Wakamatsu, H.; Muneta, K.; Murayama, T.; Ikeda, M. Fascicularones A and B from a mycelial culture of Naematoloma fasciculare. Phytochemistry 2004, 65, 491-496. [CrossRef] [PubMed]

198. Shiono, Y.; Wakamatsu, H.; Murayama, T.; Ikeda, M. Fascicularones C and D, tricycle[5.4.0.0 2.5$]$ undecane sesquiterpenoids from the liquid culture of Naematolama fasciculare. Z. Naturforsch. B Chem. Sci. 2004, 59, 119-123. [CrossRef]

199. Shiono, Y.; Akasaka, H.; Hiramatsu, F.; Sato, K.; Murayama, T.; Ikeda, M. Three sesquiterpenoids, fascicularones E, F, and G produced by the fungus Hypholoma fasciculare. Z. Naturforsch. B Chem. Sci. 2005, 60, 880-884. [CrossRef]

200. Akasaka, H.; Shiono, Y.; Murayama, T.; Ikeda, M. Fascicularones H-K, four new sesquiterpenoids from the cultured mycelia of the fungus Hypholoma fasciculare. Helv. Chim. Acta 2005, 88, 2944-2950. [CrossRef]

201. Cutler, H.; Crumley, F.G.; Cox, R.H.; Davis, E.E.; Harper, J.L.; Cole, R.J.; Sumner, D.R. Prehelminthosporol and prehelminthosporol acetate: Plant growth regulating properties. J. Agric. Food Chem. 1982, 30, 658-662. [CrossRef]

202. Pena-Rodriguez, L.M.; Armingeon, N.A.; Chilton, W.S. Toxins from weed pathogens, I. Phytotoxins from a Bipolaris pathogen of Johnson grass. J. Nat. Prod. 1988, 51, 821-828. [CrossRef] [PubMed] 
203. Pena-Rodriguez, L.M.; Chilton, W.S. Victoxinine and prehelminthosporolactone, two minor phytotoxic metabolites produced by Bipolaris sp. a pathogen of Johnson grass. J. Nat. Prod. 1989, 52, 899-901.

204. Sugawara, F.; Hallock, Y.F.; Bunkers, G.D.; Kenfield, D.S.; Strobel, G.; Yoshida, S. Phytotoxic eremophilanes produced by the weed pathogen Drechslera gigantean. Biosci. Biotech. Biochem. 1993, 57, 236-239. [CrossRef] [PubMed]

205. Bhattacharya, D.; Siddiqui, K.A.; Ali, E. Phytotoxic metabolites of Macrophomina phaseolina. Indian J. Mycol. Plant Pathol. 1992, 22, 54-57.

206. Pedras, M.S.C.; Erosa-Lopez, C.C.; Quail, J.W.; Taylor, J.L. Phomalairdenone: A new host-selective phytotoxin from a virulent type of the blackleg fungus Phoma lingam. Bioorg. Med. Chem. Lett. 1999, 9, 3291-3294. [CrossRef]

207. Pedras, M.S.C.; Chumala, P.B.; Venkatesham, U. New sesquiterpenic phytotoxins establish unprecedented relationship between different groups of blackleg fungal isolates. Bioorg. Med. Chem. 2005, 13, 2469-2475. [CrossRef]

208. Capasso, R.; Iacobellis, N.S.; Bottalico, A.; Randazzo, G. Structure-toxicity relationships of the eremophilane phomenone and PR-toxin. Phytochemistry 1984, 23, 2781-2784. [CrossRef]

209. Masi, M.; Meyer, S.; Cimmino, A.; Andolfi, A.; Evidente, A. Pyrenophoric acid, a phytotoxic sesquiterpenoid penta-2,4-dienoic acid produced by a potential mycoherbicide, Pyrenophora semeniperda. J. Nat. Prod. 2014, 77, 925-930. [CrossRef]

210. Masi, M.; Meyer, S.; Cimmino, A.; Clement, S.; Black, B.; Evidente, A. Pyrenophoric acids B and C, two new phytotoxic sesquiterpenoids produced by Pyrenophora semeniperda. J. Agric. Food Chem. 2014, 62, 10304-10311. [CrossRef]

211. Lozano-Juste, J.; Masi, M.; Cimmino, A.; Clement, S.; Fernandez, M.A.; Antoni, R. The fungal sesquiterpenoid pyrenophoric acid $B$ uses the plant ABA biosynthetic pathway to inhibit seed germination. J. Exp. Bot. 2019, 70, 5487-5494. [CrossRef]

212. Wang, A.; Yin, R.; Zhou, Z.; Gu, G.; Dai, J.; Lai, D.; Zhou, L. Eremophilane-type sesquiterpenoids from the endophytic fungus Rhizopycnis vagum and their antibacterial, cytotoxic, and phytotoxic activities. Front. Chem. 2020, 8, 596889. [CrossRef] [PubMed]

213. Ballio, A.; Morelli, M.A.C.; Evidente, A.; Graniti, A.; Randazzo, G.; Sparapano, L. Seiricardine A, a phytotoxic sesquiterpene from three Seiridium species pathogenic for cypress. Phytochemistry 1991, 30, 131-136. [CrossRef]

214. Evidente, A.; Motta, A.; Sparapano, L. Seicardines B and C, phytotoxic sesquiterpenes from three species of Seiridium pathogenic for cypress. Phytochemistry 1993, 33, 69-78. [CrossRef]

215. Nakajima, H.; Isomi, K.; Hamasaki, T.; Ichinoe, M. Sorokinianin: A novel phytotoxin produced by the phytopathogenic fungus Bipolaris sorokiniana. Tetrahedron Lett. 1994, 35, 9597-9600. [CrossRef]

216. Del Valle, P.; Figueroa, M.; Mata, R. Phytotoxic eremophilane sesquiterpenes from the coprophilous fungus Penicillium sp. G1-a14. J. Nat. Prod. 2015, 78, 339-342. [CrossRef] [PubMed]

217. Schneider, G.; Anke, H.; Sterner, O. New secondary metabolites from a mycophilic Hansfordia species. Nat. Prod. Lett. 1997, 10, 133-138. [CrossRef]

218. Perera, W.H.; Meepagala, K.M.; Wedge, D.E.; Duke, S.O. Sesquiterpenoids from culture of the fungus Stereum complicatum (Steraceae): Structural diversity, antifungal and phytotoxic activities. Phytochem. Lett. 2020, 37, 51-58. [CrossRef]

219. Ichihara, A.; Oikawa, H.; Hayashi, K.; Hashimoto, M.; Sakamura, S.; Sakai, R. 3-Deoxyaphidicolin and aphidicolin analogues as phytotoxins from Phoma betae. Agric. Biol. Chem. 1984, 48, 1687-1689. [CrossRef]

220. Cimmino, A.; Andolfi, A.; Zonno, M.C.; Avolio, F.; Santini, A.; Tuzi, A.; Berestetskyi, A.; Vurro, M.; Evidente, A. Chenopodolin: A phytotoxic unrearranged ent-pimaradiene diterpene produced by Phoma chenopodicola, a fungal pathogen for Chenopodium album biocontrol. J. Nat. Prod. 2013, 76, 1291-1297. [CrossRef] [PubMed]

221. Fernandez-Aparicio, M.; Andolfi, A.; Cimmino, A.; Rubiales, D.; Evidente, A. Stimulation of seed germination of Orobanche species by ophobolin A and fusicoccin derivatives. J. Agric. Food Chem. 2008, 56, 8343-8347. [CrossRef]

222. Ohkanda, J. Fusicoccin: A chemical modulator for 14-3-3 proteins. Chem. Lett. 2021, 50, 57-67. [CrossRef]

223. Zhao, D.-L.; Yang, L.-J.; Shi, T.; Wang, C.-Y.; Shao, C.-L.; Wang, C.-Y. Potent phytotoxic harziane diterpenes from a soft coralderived strain of the fungus Trichoderma harzianum XS-20090075. Sci. Rep. 2019, 9, 13345. [CrossRef]

224. Bodo, B.; Davoust, D.; Lecommandeur, D.; Rebuffat, S.; Genetet, I.; Pinon, J. Hymatoxin A, a diterpene sulfate phytotoxin of Hypoxylon mammatum, parasite of aspen. Tetrahedron Lett. 1987, 28, 2355-2358. [CrossRef]

225. Jossang, A.; Mbeminack, B.; Pinon, J.; Bodo, B. Hyatoxins K and L, novel phytotoxins from Hypoxylon mammatum, fungal pathogen of aspens. Nat. Prod. Lett. 1995, 6, 37-42. [CrossRef]

226. Evidente, A.; Sparapano, L.; Motta, A.; Giordano, F.; Fierro, O.; Frisullo, S. A phytotoxic pimarane diterpene of Sphaeropsis sapinea f. sp. cupressi, the pathogen of a canker disease of cypress. Phytochemistry 1996, 42, 1541-1546. [CrossRef]

227. Evidente, A.; Sparapano, L.; Fierro, O.; Bruno, G.; Giordano, F.; Motta, A. Sphaeropsidins B and C, phytotoxic pimarane diterpenes from Sphaeropsis sapinea f. sp. cupressi and Diplodia mutila. Phytochemistry 1997, 45, 705-713. [CrossRef]

228. Au, T.K.; Chick, W.S.H.; Leung, P.C. The biology of ophiobolins. Life Sci. 2000, 67, 733-742. [CrossRef]

229. Tian, W.; Deng, Z.; Hong, K. The biological activities of sesterterpenoid-type ophiobolins. Mar. Drugs 2017, 15, 229. [CrossRef]

230. Masi, M.; Dasari, R.; Evidente, A.; Mathieu, V.; Kornienko, A. Chemistry and biology of ophiobolin A and its congeners. Bioorg. Med. Chem. Lett. 2019, 29, 859-869. [CrossRef]

231. Kim, J.-M.; Hyeon, S.-B.; Isogai, A.; Suzuki, A. Isotation of ophiobolin A and its analogs as inhibitors to photosynthesis. Agric. Biol. Chem. 1984, 48, 803-805.

232. Evidente, A.; Andolfi, A.; Cimmino, A.; Vurro, M.; Fracchiolla, M.; Charudattan, R. Herbicidal potential of ophiobolins produced by Drechslera gigantean. J. Agric. Food Chem. 2006, 54, 1779-1783. [CrossRef] 
233. Pena-Rodriguez, L.M.; Chilton, W.S. 3-Anhydroophiobolin A and 3-anhydro-6-epi-ophiobolin A, phytotoxic metabolites of the Johnson grass pathogen Bipolaris sorghicola. J. Nat. Prod. 1989, 52, 1170-1172. [CrossRef]

234. Sugawara, F.; Strobel, G.; Strange, R.N.; Siedow, J.N.; Van Duyne, G.D.; Clardy, J. Phytotoxins from the pathogenic fungi Drechslera maydis and Drechelera sorghicola. Proc. Nat. Acad. Sci. USA 1987, 84, 3081-3085. [CrossRef] [PubMed]

235. Kim, H.J.; Kim, J.C.; Kim, B.S.; Kim, H.G.; Cho, K.Y. Antibiotic and phytotoxic activities of ophiobolins from Helminthosporium species. Plant Pathol. J. 1999, 15, 14-20.

236. Sugawara, F.; Takahashi, N.; Strobel, G.; Yun, C.; Gray, G.; Fu, Y.; Clardy, J. Some new phytotoxic ophiobolins produced by Drechslera oryzae. J. Org. Chem. 1988, 53, 2170-2172. [CrossRef]

237. Nihashi, Y.; Lim, C.-H.; Tanaka, C.; Miyagawa, H.; Ueno, T. Phytotoxic sesterterpene, 11-epiterpestacin, from Bipolaris sorokiniana NSDR-011. Biosci. Biotechnol. Biochem. 2002, 66, 685-688. [CrossRef]

238. Shiono, Y.; Sugawara, H.; Nazarova, M.; Mrayama, T.; Takahashi, K.; Ikeda, M. Three lanostane triterpenoids, aeruginosols A, B and C, from the fruiting bodies of Stropharia aeruginosa. J. Asian Nat. Prod. Res. 2007, 9, 531-535. [CrossRef] [PubMed]

239. Ikeda, M.; Stato, Y.; Izawa, M.; Sassa, T.; Miura, Y. Isolation and structure of fasciculol A, a new plant growth inhibitor from Neamatoloma jasciculare. Agric. Biol. Chem. 1977, 41, 1539-1541.

240. Ikeda, M.; Watanabe, H.; Hayakawa, A.; Sato, K.; Sassa, T.; Miura, Y. Structures of fasciculol B and its depsipepide, new biologically active substances from Neamatoloma jasciculare. Agric. Biol. Chem. 1977, 41, 1543-1545.

241. Ikeda, M.; Niwa, G.; Tohyama, K.; Sassa, T.; Miura, Y. Structures of fasciculol C and its depsipeptides, new biologically active substances from Neamatoloma jasciculare. Agric. Biol. Chem. 1977, 41, 1803-1805.

242. Evidente, A.; Lanzetta, R.; Abouzeid, M.A.; Corsaro, M.M.; Mugnai, L.; Surico, G. Foeniculoxin, a new phytotoxic geranylhydroquinone from Phomopsis foeniculi. Tetrahedron 1994, 50, 10371-10378. [CrossRef]

243. Masi, M.; Sautua, F.; Zatout, R.; Castaldi, S.; Arrico, L.; Isticato, R.; Pescitelli, G.; Carmona, M.A.; Evidente, A. Phaseocyclopentenones A and B, phytotoxic penta- and tetrasubstituted cyclopentenones produced by Macrophomina phaseolina, the causal agent of charcoal rot of soybean in Argentina. J. Nat. Prod. 2021, 84, 459-465. [CrossRef]

244. Cimmino, A.; Andolfi, A.; Zonno, M.C.; Troise, C.; Santini, A.; Tuzi, A.; Vurro, M.; Ash, G.; Evidente, A. Phomentrioloxin: A phytotoxic pentasubstituted geranylcyclohexentriol produced by Phomopsis sp., a potential mycoherbicide for Carthamus lanatus biocontrol. J. Nat. Prod. 2012, 75, 1130-1137. [CrossRef]

245. Cimmino, A.; Andolfi, A.; Zonno, M.C.; Boari, A.; Troise, C.; Motta, A.; Vurro, M.; Ash, G.; Evidente, A. Phomentrioloxin, a fungal phytotoxin with potential herbicidal activity, and its derivatives: A structure-activity relationship study. J. Agric. Food Chem. 2013, 61, 9645-9649. [CrossRef] [PubMed]

246. Colmenares, A.J.; Duran-Patron, R.M.; Hernandez-Galan, R.; Collando, I.G. Four new lactones from Botrytis cinera. J. Nat. Prod. 2002, 65, 1724-1726. [CrossRef] [PubMed]

247. Miyagawa, H.; Nagai, S.; Tsurushima, T.; Sato, M.; Ueno, T.; Fukami, H. Phytotoxins produced by the plant pathogenic fungus Bipolaris bicolor El-1. Biosci. Biotechnol. Biochem. 1994, 58, 143-1145. [CrossRef]

248. Long, Y.; Tang, T.; Wang, L.-Y.; He, B.; Gao, K. Absolute configuration and biological activities of meroterpenoids from an endophytic fungus of Lycium barbarum. J. Nat. Prod. 2019, 82, 2229-2237. [CrossRef] [PubMed]

249. Han, J.; Zhang, J.; Song, Z.; Zhu, G.; Liu, M.; Dai, H.; Hsiang, T.; Liu, X.; Zhang, L.; Quinn, R.J.; et al. Genome-based mining of new antimicrobial meroterpenoids from the phytopathogenic fungus Bipolaris sorokiniana strain 11134. Appl. Microbiol. Biotechnol. 2020, 104, 3835-3846. [CrossRef]

250. Yin, M.; Fasoyin, O.E.; Wang, C.; Yue, Q.; Zhang, Y.; Dun, B.; Xu, Y.; Zhang, L. Herbicidal efficacy of harzianums produced by the biofertilizer fungus, Trichoderma brevicompactum. AMB Expr. 2020, 10, 118. [CrossRef]

251. Gohbara, M.; Kosuge, Y.; Yamasaki, S.; Kimura, Y.; Suzuki, A.; Tamura, S. Isolation, structures and biological activities of colletotrichins, phytotoxic substances from Colletotrichum nicotianae. Agric. Biol. Chem. 1978, 42, 1037-1043. [CrossRef]

252. Wang, X.; Gong, X.; Li, P.; Lai, D.; Zhou, L. Structural diversity and biological activities of cyclic depsipeptides from fungi. Molecules 2018, 23, 169. [CrossRef]

253. Ueno, T.; Nakashima, T.; Hayashi, Y.; Fukami, H. Structures of AM-toxin I and II, host specific phytotoxic metabolites produced by Alternaria mali. Agric. Biol. Chem. 1975, 39, 1115-1122. [CrossRef]

254. Ueno, T.; Nakashima, T.; Hayashi, Y.; Fukami, H. Isolation and structure of AM-toxin III, a host specific phytotoxic metabolite produced by Alternaria mali. Agric. Biol. Chem. 1975, 39, 2081-2082. [CrossRef]

255. Miyashita, M.; Nakamori, T.; Miyagawa, H.; Akamatsu, M.; Ueno, T. Inhibitor activity of analogs of AM-toxin, a host-specific phytotoxin from the Alternaria alternata apple pathotype, on photosynthetic $\mathrm{O}_{2}$ evolution in apple leaves. Biosci. Biotechnol. Biochem. 2003, 67, 635-638. [CrossRef] [PubMed]

256. Evans, N.; Mcroberts, N.; Hill, R.A.; Marshall, G. Phytotoxin production by Alternaria linicola and phytoalexin production by the linseed host. Ann. Appl. Biol. 1996, 129, 415-431. [CrossRef]

257. Bains, P.S.; Tewari, J.P. Purificaiton, chemical characterization and host-specificity of the toxin produced by Alternaria brassicae. Physiol. Mol. Plant Pathol. 1987, 30, 259-271. [CrossRef]

258. Pedras, M.S.C.; Zaharia, I.L.; Gai, Y.; Smith, K.C.; Ward, D.E. Metabolism of the hsot-selective toxins destruxin B and homodestruxin B: Probing a plant disease resistance trait. Org. Lett. 1999, 1, 1655-1658. [CrossRef]

259. Hornbogen, T.; Glinski, M.; Zocher, R. Biosynthesis of depsipeptide mycotoxins in Fusarium. Eur. J. Plant Pathol. 2002, 108, 713-718. [CrossRef] 
260. Burmeister, H.R.; Plattner, R.D. Enniatin production by Fusarium tricinctum and its effect on germinating wheat seeds. Phytopathology 1987, 77, 1483-1487. [CrossRef]

261. Herrmann, M.; Zocher, R.; Haese, A. Enniatin production by Fusarium strains and its effect on potato tuber tissue. Appl. Environ. Microbiol. 1996, 62, 393-398. [CrossRef]

262. Hershenhorn, J.; Park, S.H.; Stierle, A.; Strobel, G.A. Fusarium avenaceum as a novel pathogen of spotted knapweed and its phytotoxins, acetamido-butenolide and enniatin B. Plant Sci. 1992, 86, 155-160. [CrossRef]

263. Bahadoor, A.; Brauer, E.K.; Bosnich, W.; Schneiderman, D.; Johnston, A.; Aubin, Y.; Blackwell, B.; Melanson, J.E.; Harris, L.J. Gramillin A and B: Cyclic lipopeptides identified as the nonribosomal biosynthetic products of Fusarium graminearum. J. Am. Chem. Soc. 2018, 140, 16783-16791. [CrossRef]

264. Pedras, M.S.C.; Biesenthal, C.J. Production of the host-selective phytotoxin phomalideby isolates of Leptosphaeria maculans and its correlation with sirodesmin PL production. Can. J. Microbiol. 1998, 44, 547-553. [CrossRef]

265. Zabka, M.; Drastichova, K.; Jegorov, A.; Soukupova, J.; Nedbal, L. Direct evidence of plant-pathogenic activity of fungal metabolites of Trichothecium roseum on apple. Mycopathologia 2006, 162, 65-68. [CrossRef] [PubMed]

266. Wang, X.; Li, Y.; Zhang, X.; Lai, D.; Zhou, L. Structrual diversity and biological activities of the cyclodipeptides from fungi. Molecules 2017, 22, 2026. [CrossRef]

267. Wang, X.; Lin, M.; Xu, D.; Lai, D.; Zhou, L. Structural diversity and biological activities of fungal cyclic peptides, excluding cyclodipeptides. Molecules 2017, 22, 2069. [CrossRef] [PubMed]

268. Zhang, Q.; Wang, S.-Q.; Tang, H.-Y.; Li, X.-J.; Zhang, L.; Xiao, J.; Gao, Y.-Q.; Zhang, A.-L.; Gao, J.-M. Potential allelopathic indole diketopiperazines produced by the plant endophytic Aspergillus fumigatus using the one strain-many compounds method. $J$. Agric. Food Chem. 2013, 61, 11447-11452. [CrossRef] [PubMed]

269. Stierle, A.C.; Cardellina II, J.H.; Strobel, G.A. Maculosin, a host-specific phytotoxin for spotted knapweed from Alternaria alternata. Proc. Natl. Acad. Sci. USA 1988, 85, 8008-8011. [CrossRef]

270. Pedras, M.S.C.; Abrams, S.R.; Séguin-Swartz, G.; Quail, J.W.; Jia, Z.C. Phomalirazine, a novel toxin from the phytopathogenic fungus Phoma lingam. J. Am. Chem. Soc. 1989, 111, 1904-1905. [CrossRef]

271. Pedras, M.S.C.; Biesenthal, C.J. Isolation, structure determination, and phytotoxicity of unusual dioxopiperazines from the phytopathogenic fungus Phoma lingam. Phytochemistry 2001, 58, 905-909. [PubMed]

272. Pedras, M.S.C.; Séguin-Swartz, G.; Abrams, S.R. Minor phytotoxins from the blackleg fungus Phoma lingam. Phytochemistry 1990, 29, 777-782. [CrossRef]

273. Mitrovic, P.M.; Orcic, D.Z.; Sakac, V.O.; Marjanovic-Jeromela, A.M.; Grahovac, N.L.; Milosevic, D.M.; Marisavljevic, D.P. Characerization of sirodesmins isolated from the phytopathogenic fungus Leptosphaeria macuans. J. Serb. Chem. Soc. 2012, 77, 1363-1379. [CrossRef]

274. Jin, J.; Baek, S.-R.; Lee, K.-R.; Lee, J.; Yun, S.-H.; Kang, S.; Lee, Y.-W. Purification and phytotoxicity of apicidins produced by the Fusarium semitectum KCTC16676. Plant Pathol. J. 2008, 24, 417-422. [CrossRef]

275. Gupta, S.; Peiser, G.; Nkajima, T.; Hwang, Y.-S. Characterization of a phytotoxic cyclotetrapeptide, a novel chlamydocin analogue, from Verticillium coccosporum. Tetrahedron Lett. 1994, 35, 6009-6012. [CrossRef]

276. Isogai, A.; Takayama, S.; Hirota, A.; Suzuki, A. Determination of the absolute stereochemistry of the epoxide of aoe (2-amino-8oxa-9,10-epoxy-decanoic acid) in Cyl-1 and Cyl-2 by CD spectra. Agric. Biol. Chem. 1986, 50, 517-518.

277. Takayama, S.; Lsogai, A.; Nakata, M.; Suzuki, H.; Susuki, A. Structure of Cyl-1, a novel cyclic tetrapetide from Cylindrocladium scoparium. Agric. Biol. Chem. 1984, 48, 839-842.

278. Hirota, A.; Suzuki, A.; Aizawa, K.; Tamura, S. Structure of Cyl-2, a novel cyclopeptide from Cylindrocladium scoparium. Agric. Biol. Chem. 1973, 37, 955-956. [CrossRef]

279. Liesch, J.M.; Sweeley, C.C.; Staffeld, G.D.; Anderson, M.S.; Weber, D.J.; Scheffer, R.P. Structure of HC-toxin, a cyclic tetrapeptide from Helminthosporium carbonum. Tetrahedron 1982, 38, 45-48. [CrossRef]

280. Rasmussen, J.B.; Scheffer, R.P. Isolation and biological activities of four selective toxins from Helminthosporium carbonum. Plant Physiol. 1988, 86, 187-191. [CrossRef]

281. Kinoshita, T.; Kono, Y.; Takeuchi, S.; Daly, J.M. Structure of HV-toxin M, a host-specific toxin-related compound produced by Helminthosporium victoriae. Agric. Biol. Chem. 1989, 53, 1283-1290. [CrossRef]

282. Allen, J.G.; Hancock, G.R. Evidence that phomopsins A and B are not the only toxic metabolites produced by Phomopsis leptostromiformis. J. Appl. Toxicol. 1989, 9, 83-89. [CrossRef]

283. Culvenor, C.C.J.; Edgar, J.A.; Mackay, M.F.; Gorst-Allman, C.P.; Marasas, W.F.O.; Steyn, P.S.; Vleggaar, R.; Wessels, P.L. Structure elucidation and absolute configuration of phomopsin A, a hexapeptide mycotoxin produced by Phomopsis leptostromiformis. Tetrahedron 1989, 45, 2351-2372. [CrossRef]

284. Liebermann, B.; Koelblin, R. A new phytotoxic activity of the cyclic peptides tentoxin and dihydrotentoxin. J. Phytopathol. 1992, 135, 245-250. [CrossRef]

285. Liebermann, B.; Ellinger, R.; Pinet, E. Isotentoxin, a conversion product of the phytotoxin tentoxin. Phytochemistry 1996, 42, 1537-1540. [CrossRef]

286. Horiuchi, M.; Ohnishi, K.; Iwase, N.; Nakajima, Y.; Tounai, K.; Yamashita, M.; Yamada, Y. A novel isoindoline, porritoxin sulfonic acid, from Alternaria porri and the structure-phytotoxicity correlation of its related compounds. Biosci. Biotechnol. Biochem. 2003, 67, 1580-1583. [CrossRef] 
287. Wolpert, T.J.; Macko, V.; Acklin, W.; Jaun, B.; Seibl, J.; Meili, J.; Arigoni, D. Structure of victorin C, the major host-selective toxin from Cochliobolus victoriae. Experientia 1985, 41, 1524-1529. [CrossRef]

288. Liakopoulou-Kyriakides, M.; Lagopodi, A.L.; Thanassoulopoulos, C.C.; Stavropoulos, G.S.; Magafa, V. Isolation and synthesis of a host-selective toxin produced by Alternaria alternata. Phytochemistry 1997, 45, 37-40. [CrossRef]

289. Pedras, M.S.C.; Chumala, P.B.; Quail, J.W. Chemical mediators: The remarkable structure and host-selectivity of depsilairdin, a sesquiterpenic depsipeptide containing a new amino acid. Org. Lett. 2004, 6, 4615-4617. [CrossRef]

290. Capio, E.R.; Tate, M.E.; Wallwork, H. Phytotoxic metabolites from Drechslera wirrenganensis and D. campanulata. Australas. Plant Pathol. 2004, 33, 23-28. [CrossRef]

291. Biasetto, C.R.; Somensi, A.; Abdalla, V.C.P.; De Abreu, L.M.; Gualtieri, S.C.J.; Pfenning, L.H.; Bolzani, V.S.; Araujo, A.R. Phytotoxic constituents from endophytic fungus Xylaria cubensis associated with Eugenia brasiliensis. Quim. Nova 2019, 42, 485-488. [CrossRef]

292. Latif, Z.; Strange, R.N.; Bilton, J.; Riazuddin, S. Production of the phytotoxins, solanapyrones A and C and cytochalasin D among nine isolates of Ascochyta rabiei. Plant Pathol. 1993, 42, 172-180. [CrossRef]

293. Cimmino, A.; Andolfi, A.; Berestetskiy, A.; Evidente, A. Production of phytotoxins by Phoma exigua var. exigua, a potential mycoherbicide against perennial thistles. J. Agric. Food Chem. 2008, 56, 6304-6309. [CrossRef]

294. Li, H.; Wei, H.; Hu, J.; Lacey, E.; Sobolev, A.N.; Stubbs, K.A.; Solomon, P.S.; Chooi, Y.-H. Genomics-driven discovery of phytotoxic cytochalasans involved in the virulence of the wheat pathogen Parastagonospora nodorum. ACS Chem. Biol. 2020, 15, $226-233$. [CrossRef]

295. Nukina, M. Pyrichalasin H, a new phytotoxic metabolite belonging to the cytochalasans from Pyricularia grisea (Cooke) Saccardo. Agric. Biol. Chem. 1987, 51, 2625-2628. [CrossRef]

296. Sassa, T.; Onuma, Y. Isolation and identification of fruit rot toxins from the fungus-caused Macrophoma fruit rot of apple. Agric. Biol Chem. 1983, 47, 1155-1157. [CrossRef]

297. Evidente, A.; Fiore, M.; Bruno, G.; Sparapano, L.; Motta, A. Chemical and biological characterisation of sapinopyridione, a phytotoxic 3,3,6-trisubstituted-2,4-pyridione produced by Sphaeropsis sapinea, a toxigenic pathogen of native and exotic conifers, and its derivatives. Phytochemistry 2006, 67, 1019-1028. [CrossRef]

298. Kumarihamy, M.; Rosa, L.H.; Techen, N.; Ferreira, D.; Croom, E.M.; Duke, S.O.; Tekwani, B.L.; Khan, S.; Nanayakkara, N.P.D. Antimalarials and phytotoxins from Botryosphaeria dothidea identified from a seed of diseased Torreya taxifolia. Molecules 2021, 26, 59. [CrossRef] [PubMed]

299. Macko, V.; Stimmel, M.B.; Wopert, T.J.; Dunkle, L.D.; Acklin, W.; Banteli, R.; Jaun, B.; Arigoni, D. Structure of the host-specific toxins produced by the fungal pathogen Periconia circinata. Proc. Natl. Acad. Sci. USA 1992, 89, 9574-9578. [CrossRef]

300. Evidente, A.; Cimmino, A.; Andolfi, A.; Vurro, M.; Zonno, M.C.; Cantrell, C.L.; Motta, A. Phyllostictines A-D, oxazatricycloalkenones produced by Phyllosticta cirsii, a potential mycoherbicide for Cirsium arvense biocontrol. Tetrahedron 2008, 64, 1612-1619. [CrossRef]

301. Suemitsu, R.; Ohnishi, K.; Horiuchi, M.; Kitaguchi, A.; Odamura, K. Porritoxin, a phytotoxin of Alternaria porri. Phytochemistry 1992, 31, 2325-2326. [CrossRef]

302. Horiuchi, M.; Maoka, T.; Iwase, N.; Ohnishi, K. Reinvestigation of structure of porritoxin, a phytotoxin of Alternaria porri. J. Nat. Prod. 2002, 65, 1204-1205. [CrossRef] [PubMed]

303. Masi, M.; Meyer, S.; Clement, S.; Andolfi, A.; Cimmino, A.; Evidente, A. Spirostaphylotrichin W, a spirocyclic $\gamma$-lactam isolated from liquid culture of Pyrenophora semeniperda, a potential mycoherbicide for cheatgrass (Bromus tectorum) biocontrol. Tetrahedron 2014, 70, 1497-1501. [CrossRef]

304. Liu, Y.-X.; Xu, X.M.; Dai, X.-B.; Qiang, S. Alternaria alternata crofton-weed toxin: A natural inhibitor of photosystem II in Chlamydomonas reinhardtii thylakoids. J. Agric. Food Chem. 2007, 55, 5180-5185. [CrossRef]

305. Kono, Y.; Gardner, J.M.; Takeuchi, S. Nonselective phytotoxins simultaneously produced with host-selective ACTG-toxins by a pathotype of Alternaria citri causing brown spot disease of mandarins. Agric. Biol. Chem. 1986, 50, 2401-2403. [CrossRef]

306. Sattar, A.; Alam, M.; Janardhanan, K.K.; Husain, A. Isolation of tenuazonic acid, a phytotoxin from Alternaria crassa (Sacc.) rands causing leaf blight and fruit rot of Datura stramonium Mill. Curr. Sci. 1986, 55, 195-196.

307. Davis, N.D.; Diener, U.L.; Morgan-Jones, G. Tenuazonic acid production by Alternaria alternata and Alternaria tenuissima isolated from cotton. Appl. Environ. Microbiol. 1977, 34, 155-157. [CrossRef] [PubMed]

308. Umetsu, N.; Kaji, J.; Tamari, K. Investigation on the toxin production by several blast fungus strains and isolation of tenuazonic acid as a novel toxin. Agric. Biol. Chem. 1972, 36, 859-866. [CrossRef]

309. Steyn, P.S.; Rabie, C.J. Characterization of magnesium and calcium tenuazonate from Phoma sorghina. Phytochemistry 1976, 15, 1977-1979. [CrossRef]

310. Chen, S.; Xu, X.; Dai, X.; Yang, C.; Qiang, S. Identification of tenuazonic acid as a novel type of natural photosystem II inhibitor binding in Q(B)-site of Chlamydomonas reinhardtii. Biochim. Biophys. Acta 2007, 1767, 306-318. [CrossRef]

311. Chen, S.; Yin, C.; Qiang, S.; Zhou, F.; Dai, X. Chloroplastic oxidative burst induced by tenuazonic acid, a natural photosynthesis inhibitor, triggers cell necrosis in Eupatorium adenophorum Spreng. Biochim. Biophys. Acta 2010, 1797, 391-405. [CrossRef]

312. Chen, S.; Kim, C.; Lee, J.M.; Lee, H.A.; Fei, Z.; Wang, L.; Apel, K. Blocking the QB-binding site of photosystem II by tenuazonic acid, a non-host-specific toxin of Alternaria alternata, activates singlet oxygen-mediated and EXECUTER-dependent signalling in Arabidopsis. Plant Cell Environ. 2015, 38, 1069-1080. [CrossRef] 
313. Chen, S.; Qiang, S. Recent advances in tenuazonic acid as a potential herbicide. Pestic. Biochem. Physiol. 2017, $143,252-257$. [CrossRef]

314. Sugawara, F.; Takahashi, N.; Strobel, G.A.; Strobel, S.A.; Lu, H.S.M.; Clardy, J. Triticones A and B, novel phytotoxins from the plant pathogenic fungus Drechelera tritici-repentis. J. Am. Chem. Soc. 1988, 110, 4086-4087. [CrossRef]

315. Yokoyama, Y.; Koseki, T.; Harneti, D.; Maharani, R.; Supratman, U.; Shiono, Y. Phytotoxic compounds isolated from a sea snail derived fungus, Penicillium vancouverense YY-1. Phytochem. Lett. 2020, 39, 57-63. [CrossRef]

316. Wang, Z.-F.; Zhang, W.; Xiao, L.; Zhou, Y.-M.; Du, F.-Y. Characterization and bioactive potentials of secondary metabolites from Fusarium chlamydosporum. Nat. Prod. Res. 2020, 34, 889-892. [CrossRef] [PubMed]

317. Masi, M.; Cimmino, A.; Boari, A.; Zonno, M.C.; Gorecki, M.; Pescitelli, G.; Tuzi, A.; Vurro, M.; Evidente, A. Colletopyrandione, a new phytotoxic tetrasubstituted indolylidenepyran-2,4-dione, and colletochlorins $\mathrm{G}$ and $\mathrm{H}$, new tetrasubstituted chroman- and isochroman-3,5-diols isolated from Colletothichum higginsianum. Tetrahedron 2017, 73, 6644-6650. [CrossRef]

318. Sugawara, F.; Strobel, G.A. Tryptophol, a phytotoxin produced by Drechslera nodulosum. Phytochemistry 1987, $26,1349-1351$. [CrossRef]

319. Evidente, A.; Andolfi, A.; Abouzeid, M.A.; Vurro, M.; Zonno, M.C.; Motta, A. Ascosonchine, the enol tautomer of 4-pyridylpyruvic acid with herbicidal activity produced by Ascochyta sonchi. Phytochemistry 2004, 65, 475-480. [CrossRef]

320. Reveglia, P.; Cinelli, T.; Cimmino, A.; Masi, M.; Evidente, A. The main phytotoxic metabolite produced by a strain of Fusarium oxysporum inducing grapevine plant declining in Italy. Nat. Prod. Res. 2018, 32, 2398-2407. [CrossRef]

321. Wang, X.; Ng, T.B. Phamacological activities of fusaric acid (5-butylpicolinic acid). Life Sci. 1999, 65, 849-856. [CrossRef]

322. Capasso, R.; Evidente, A.; Cutignano, A.; Vurro, M.; Zonno, M.C.; Bottalico, A. Fusaric and 9,10-dehydrofusaric acids and their methylesters from Fusarium nygamai. Phytochemistry 1996, 41, 1035-1039. [CrossRef]

323. Liu, S.; Dai, H.; Orfali, R.S.; Lin, W.; Liu, Z.; Proksch, P. New fusaric acid derivatives from the endophytic fungus Fusarium oxysporum and their phytotoxicity to barley leaves. J. Agric. Food Chem. 2016, 64, 3127-3132. [CrossRef]

324. Bottini, A.T.; Gilchrist, D.G. Phytotoxins. I. A 1-aminodimethylheptadecapentol from Alternaria alternata f.sp. lycopersici. Tetrahedron Lett. 1981, 22, 2719-2722. [CrossRef]

325. Bottini, A.T.; Bowen, J.R.; Gilchrist, D.G. Phytotoxins. II. Characterization of a phytotoxic fraction from Alternaria alternata f.sp. lycopersici. Tetrahedron Lett. 1981, 22, 2723-2726. [CrossRef]

326. Caldas, E.D.; Jones, A.D.; Ward, B.; Winter, C.K.; Gilchrist, D.G. Structural characterization of three new AAL toxins produced by Alternaria alternata f.sp. lycopersici. J. Agric. Food Chem. 1994, 42, 327-333. [CrossRef]

327. Winter, C.K.; Gilchrist, D.G.; Dickman, M.B.; Jones, C. Chemistry and biological activity of AAL toxins. Adv. Exp. Med. Biol. 1996, 392, 307-316. [PubMed]

328. Brandwagt, B.F.; Mesbah, L.A.; Takken, F.L.W.; Laurent, P.L.; Kneppers, T.J.A.; Hille, J.; Nijkamp, H.J. A longevity assurance gene homolog of tomato mediates resistance to Alternaria alternata f.sp. lycopersici toxins and fumonisin B1. Proc. Natl. Acad. Sci. USA 2000, 97, 4961-4966. [CrossRef] [PubMed]

329. Kohmoto, K.; Itoh, Y.; Shimomura, N.; Kondoh, Y.; Otani, H.; Kodama, M.; Nishimura, S.; Nakatsuka, S. Isolation and biological activities of two host-specific toxins from the tangerine pathotype of Alternaria alternata. Phytopathology 1993, 83, 495-502. [CrossRef]

330. Ueno, T. Secondary metabolites related to host selection by plant pathogenic fungi. Pure Appl. Chem. 1990, 62, 1347-1352. [CrossRef]

331. Weiergang, I.; Lyngs Jorgensen, H.J.; Moller, I.M.; Friis, P.; Smedegaard-Petersen, V. Optimization of in vitro growth conditions of Pyrenophora teres for production of the phytotoxin aspergillomarasmine A. Physiol. Mol. Plant Pathol. 2002, 60, 131-140. [CrossRef]

332. Irvine, N.M.; Yerkes, C.N.; Graupner, P.R.; Roberts, R.E.; Hahn, D.R.; Pearce, C.; Gerwick, B.C. Synthesis and characterization of synthetic analogs of cinnacidin, a novel phytotoxin from Nectria sp. Pest. Manag. Sci. 2008, 64, 891-899. [CrossRef]

333. Lamprecht, S.C.; Marasas, W.F.O.; Alberts, J.F.; Cawood, M.E.; Gelderblom, W.C.A.; Shephard, G.S.; Thiel, P.G.; Calitz, F.J. Phytotoxicity of fumonisins and TA-toxin to corn and tomato. Phytopathology 1994, 84, 383-391. [CrossRef]

334. Wang, A.; Li, P.; Han, P.; Gu, G.; Shan, T.; Lai, D.; Zhou, L. New nitrogen-containing metabolites from cultures of rice flase smut pathogen Villosiclava virens. Nat. Prod. Res. 2021, 35, 272-281. [CrossRef] [PubMed]

335. Pedras, M.S.C.; Chumala, P.B.; Jin, W.; Islam, M.S.; Hauck, D.W. The phytopathogenic fungus Alternaria brassicicola: Phytotoxin production and phytoalexin elicitation. Phytochemistry 2009, 70, 394-402. [CrossRef]

336. Hershenhorn, J.; Vurro, M.; Zonno, M.C.; Stierle, A.; Strobel, G. Septoria cirsii, a potential biocontrol agent of Canada thistle and its phytotoxin- $\beta$-nitropropionic acid. Plant Sci. 1993, 94, 227-234. [CrossRef]

337. Coval, S.J.; Hradil, C.M.; Lu, H.S.M.; Clardy, J.; Satouri, S.; Strobel, G.A. Pyrenoline-A and -B, two new phytotoxins from Pyrenophora teres. Tetraheron Lett. 1990, 31, 2117-2120. [CrossRef]

338. Nagata, T.; Ando, Y.; Hirota, A. Phytotoxins from tea gray blight fungi, Pestalotiopsis longiesta and Pestalotiopsis theae. Biosci. Biotechnol. Biochem. 1992, 56, 810-811. [CrossRef] [PubMed]

339. El-Demerdash, A.; Genta-Jouve, G.; Barenstrauch, M.; Kunz, C.; Baudouin, E.; Prado, S. High oxygenated isoprenylated cyclohexanoids from the fungus Parastagonospora nodorum SN15. Phytochemistry 2019, 166, 112056. [CrossRef] [PubMed]

340. Kenfield, D.; Bunkers, G.; Strobel, G.A.; Sugawara, F. Potential new herbicides-phytotoxins from plant pathogens. Weed Technol. 1988, 2, 519-524. [CrossRef]

341. Abbas, H.K.; Duke, S.O. Phytotoxins from plant pathogens as potential herbicides. Toxin Rev. 1995, 14, 523-543. [CrossRef] 
342. Rossi, M.; Wen, K.; Caruso, F.; Belli, S. Emodin scavenging of superoxide radical includes $\pi-\pi$ interaction. X-ray crystal structure, hydrodynamic voltammetry and theoretical studies. Antioxidants 2020, 9, 194. [CrossRef]

343. Wei, W.-T.; Lin, S.-Z.; Liu, D.-L.; Wang, Z.-H. The distinct mechanisms of the antitumor activity of emodin in different types of cancer (review). Oncol. Rep. 2013, 30, 2555-2562. [CrossRef] [PubMed]

344. Shang, X.-F.; Zhao, Z.-M.; Li, J.-C.; Yang, G.-Z.; Liu, Y.-Q.; Dai, L.-X.; Zhang, Z.-J.; Yang, Z.-G.; Miao, X.-L.; Yang, C.-J.; et al. Insecticidal and antifungal activities of Rheum palmatum L. anthraquinones and structurally related compounds. Ind. Crop Prod. 2019, 137, 508-520. [CrossRef]

345. Xu, Y.; Mafezoli, J.; Oliveira, M.C.F.; U’Ren, J.M.; Arnold, A.E.; Gunatilaka, A.A.L. Anteaglonialides A-F and palmarumycins $\mathrm{CE}_{1}-\mathrm{CE}_{3}$ from Anteaglonium sp. FL0768, a fungal endophyte of the spikemoss Selaginella arenicola. J. Nat. Prod. 2015, 78, $2738-2747$. [CrossRef] [PubMed]

346. Paranagama, P.A.; Wijeratne, E.M.K.; Burns, A.M.; Marron, M.T.; Gunatilaka, M.K.; Arnold, A.E.; Gunatilaka, A.A.L. Heptaketides from Corynespora sp. inhabiting the cavern beard lichen, Usnea cavernosa: First report of metabolites of an endolichenic fungus. J. Nat. Prod. 2007, 70, 1700-1705. [CrossRef] 